\title{
pombalina
}

(8)

\section{Odes e Fragmentos}

Autor(es): $\quad$ Baquílides; Jesus, Carlos A. Martins de, trad., coment.

Publicado por: Imprensa da Universidade de Coimbra; Annablume Editora

URL

persistente:

URI:http://hdl.handle.net/10316.2/31798

DOI:

DOI:http://dx.doi.org/10.14195/978-989-721-046-4

Accessed : $\quad$ 26-Apr-2023 14:45:22

A navegação consulta e descarregamento dos títulos inseridos nas Bibliotecas Digitais UC Digitalis, UC Pombalina e UC Impactum, pressupõem a aceitação plena e sem reservas dos Termos e Condições de Uso destas Bibliotecas Digitais, disponíveis em https://digitalis.uc.pt/pt-pt/termos.

Conforme exposto nos referidos Termos e Condições de Uso, o descarregamento de títulos de acesso restrito requer uma licença válida de autorização devendo o utilizador aceder ao(s) documento(s) a partir de um endereço de IP da instituição detentora da supramencionada licença.

Ao utilizador é apenas permitido o descarregamento para uso pessoal, pelo que o emprego do(s) título(s) descarregado(s) para outro fim, designadamente comercial, carece de autorização do respetivo autor ou editor da obra.

Na medida em que todas as obras da UC Digitalis se encontram protegidas pelo Código do Direito de Autor e Direitos Conexos e demais legislação aplicável, toda a cópia, parcial ou total, deste documento, nos casos em que é legalmente admitida, deverá conter ou fazer-se acompanhar por este aviso. 


\section{BAQUílLIDES}

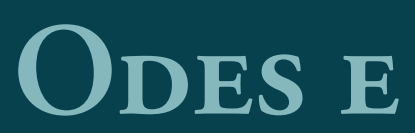

\section{Fragmentos}

TRADUÇÃO DO GREGO, INTRODUÇÃO E COMENTÁRIO Carlos A. Martins de Jesus

IMPRENSA DA UNIVERSIDADE DE COIMBRA COIMBRA UNIVERSITY PRESS 
Apresentaçáo: Esta série procura apresentar em língua portuguesa obras de autores gregos, latinos e neolatinos, em tradução feita diretamente a partir da língua original. Além da tradução, todos os volumes são também caraterizados por conterem estudos introdutórios, bibliografia crítica e notas. Reforça-se, assim, a originalidade científica e o alcance da série, cumprindo o duplo objetivo de tornar acessíveis textos clássicos, medievais e renascentistas a leitores que náo dominam as línguas antigas em que foram escritos. Também do ponto de vista da reflexão académica, a coleção se reveste no panorama lusófono de particular importância, pois proporciona contributos originais numa área de investigação científica fundamental no universo geral do conhecimento e divulgaçáo do património literário da Humanidade.

Periodicidade: trimestral

\section{Estruturas Editoriais}

Coordenadores Gerais (General Editors)

A. Centro de Estudos Clássicos e Humanísticos (Coimbra)

- Delfim Leão (Universidade de Coimbra)

- José Ribeiro Ferreira (Universidade de Coimbra)

- Luísa Portocarrero (Universidade de Coimbra)

- Maria do Céu Fialho (Universidade de Coimbra)

- Sebastiāo Pinho (Universidade de Coimbra)

B. Annablume (São Paulo)

- Gabriele Cornelli (Universidade de Brasília)

- Jacyntho Lins Brandão (Universidade Federal de Minas Gerais)

- Pedro Paulo Funari (Universidade Estadual de Campinas)

Diretor Principal (Main Editor)

- Carmen Leal Soares (Universidade de Coimbra)

- Maria de Fátima Silva (Universidade de Coimbra)

Assistentes editoriais (Editorial Assistants)

- Elisabete Caçáo

- João Pedro Gomes

- Nelson Ferreira

Comissáo Científica (Editorial Board)

- Adriane Duarte (Universidade de São Paulo)

- Aurelio Pérez Jiménez (Universidad de Málaga)

- Graciela Zeccin (Universidade de La Plata)

- Fernanda Brasete (Universidade de Aveiro)

- Fernando Brandāo dos Santos (UNESP, Campus de Araraquara)

- Francesc Casadesús Bordoy (Universitat de les Illes Balears)

- Frederico Lourenço (Universidade de Coimbra)

- Joaquim Pinheiro (Universidade da Madeira)

- Lucía Rodríguez-Noriega Guillen (Universidade de Oviedo)

- Jorge Deserto (Universidade do Porto)

- Maria José García Soler (Universidade do País Basco)

- Susana Marques Pereira (Universidade de Coimbra) 


\section{BAQUíLIDES}

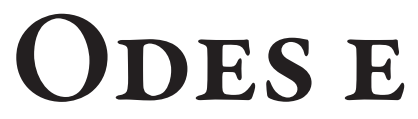

\section{FRAGMENTOS}

TRADUÇÃo DO GREGO, INTRODUÇÃO E COMENTÁRIO

Carlos A. Martins de Jesus 


\title{
Título • Odes e Fragmentos
}

\section{Autor • Baquílides}

\author{
Traduçấo do grego, introduçấo e comentário • Carlos A. Martins \\ de Jesus
}

Coedição

Imprensa da Universidade de Coimbra

URL: http://www.uc.pt/imprensa_uc

E-mail: imprensa@uc.pt

Vendas online:

http://livrariadaimprensa.uc.pt

Annablume editora $\cdot$ comunicaçấo

www.annablume.com.br

\section{COORDENAÇÃo EDITORIAL}

Imprensa da Universidade de Coimbra

Concepção gráfica e Paginação

Rodolfo Lopes, Nelson Ferreira

INFOGRAFIA

Imprensa da Universidade de Coimbra
Impressáo e Acabamento

WWW. ARTIPOL.NET

ISSN

2183-220X

ISBN

978-989-721-045-7

ISBN DigITAL

978-989-721-046-4

\section{DOI}

http://dx.doi.org/10.14195/978-989-721-046-4

Depósito Legal

375102/14

I a EdiçÃo: IUC • 2014

(C) Abril 2014.

Annablume editora - Sáo Paulo

Imprensa da Universidade de Coimbra

Classica Digitalia Vniversitatis Conimbrigensis (http://classicadigitalia.uc.pt) Centro de Estudos Clássicos e Humanísticos da Universidade de Coimbra

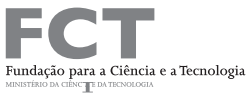

\section{POCI/2010}

Reservados todos os direitos. Nos termos legais fica expressamente proibida a reprodução total ou parcial por qualquer meio, em papel ou em edição electrónica, sem autorizaçâo expressa dos titulares dos direitos. É desde já excepcionada a utilização em circuitos académicos fechados para apoio a leccionaçấo ou extensāo cultural por via de e-learning.

TODOS OS VOLUMES DESTA SÉRIE SÃO SUJEITOS A ARBITRAGEM CIENTÍFICA INDEPENDENTE. 


\section{SuMÁRIO}

Sobre A PRESENTE EDIÇÃO

INTRODUÇÃO

1. RecuperaÇÃo E CONHECIMENTO DE UM POETA

2. Percursos poéticos pelo mundo grego

3. TransmissÃo E APROXIMAÇŌES CRÍticas

4. BibLIOGRAFIA

EPINÍCIOS

Ditirambos

Fragmentos

ApÊndices

Apêndice 1

Apêndice 2

ÍNDICE TEMÁTICO 
(Página deixada propositadamente em branco) 


\section{SOBRE A PRESENTE EDIÇÃO}

A menos que o contrário se indique, a edição que seguimos para a tradução de todo o corpus conservado de Baquílides é a teubneriana de H. Maehler ( $\left.{ }^{11} 2003\right)$. Procurámos uma tradução em verso branco que, não mantendo naturalmente a riquíssima métrica do original, permitisse ainda assim observar a estrutura triádica da maioria das composiçóes (estrofe, antístrofe e epodo). Foi nosso propósito reduzir ao mínimo indispensável as notas à tradução, de forma a que estas explicassem apenas as referências incompreensíveis ao leitor não especialista em literatura grega, mas sempre buscando que a beleza do texto de Baquílides - mesmo na sua pálida imagem em traduçáo - falasse por si. Ainda assim, a especificidade mítica ou de circunstâncias da maioria das odes e fragmentos levou, tantas vezes, à sua proliferação. Quando abreviados, os títulos de publicaçóes periódicas vêm referidos pelas siglas de L’Année Philologique.

As introduçóes às odes completas ou grupos de odes pretendem elucidar o leitor sobre questôes de datação, 
contextos de produção e performance das mesmas, além dos mitos que algumas delas atualizam, a cada passo remetendo para as notas de pé de página que acompanham a tradução.

Reunimos em dois apêndices, respetivamente: Apêndice 1: as fontes de transmissão indireta dos fragmentos traduzidos na primeira parte - quando náo transmitidos pelo Papiro de Londres -, bem assim os testemunhos sobre esses textos, que tantas vezes constituem em si um fragmento por via da citaçáo de outro autor - neste último caso, o número do fragmento vem seguido da indicação $(*)$. Apêndice 2: testemunhos antigos sobre a vida e obra de Baquílides. Não transmitindo, em grande parte dos casos, texto do poeta ou a ele atribuído com segurança, estes dados pareceram-nos ainda assim essenciais para que a presente ediçâao fosse o mais completa e útil possível.

Ao longo do volume, com frequência ocorrem os seguintes símbolos e abreviaturas:

... ou $(\ldots)$

(?) parcela de texto perdido no Papiro. parcela de texto perdida mas reconstruída pelo sentido.

], [ ou [...] à direita, à esquerda ou dentro de parêntesis retos se inclui o texto perdido mas reconstituído por algum editor.

]], [[, [[...]] à direita, à esquerda ou dentro de parêntesis retos duplos se traduzem parcelas de texto reconstituídas apenas pelo sentido provável.

c.

Comm.

Dit.

Ep.

fr./ frs.

$I G$ cerca de (dataçóes).

Comentário.

Ditirambo.

Epinício.

fragmento(s).

Inscriptiones Graecae. 
P.

P. Oxy.

Test.
Papiro.

Papiro de Oxirrinco.

Testemunho(s).

Coimbra 2013 
(Página deixada propositadamente em branco) 


\section{INTRODUÇẤO}

\section{Recuperação e CONHECimento de Um POETA}

Embora o seu nome fizesse parte das listas antigas dos nove líricos maiores dos Gregos, até ao final do século XIX era ínfima a quantidade de texto que se conhecia de Baquílides, ele que, por essa altura, foi o protagonista de uma das mais importantes descobertas papirológicas de que há memória, no que à literatura grega diz respeito. ${ }^{1}$ Estávamos em 1896 quando, num túmulo da aldeia de Meir, perto de AlKussîyah, no Egito, um grupo de nativos descobriu o rolo de papiro (P. Br. Bibl. 733 = P. Lit. Lond. 46) que viria a ser identificado como contendo grande parte de uma edição de Baquílides, datada por F. G. Kenyon 1897: xviii-xx - o autor da editio princeps - do século I a.C. O imenso trabalho de organização, leitura e fixação textual de Kenyon, embora tenha depois sido melhorado e corrigido em muitos pontos, simplesmente presenteou o mundo com um novo poeta grego. Um poeta que, sabemos e aceitamos hoje sem pudor, trabalhou para os mesmos patronos, elogiou alguns dos mesmos vencedores e compôs para as mesmas cidades que o grande Píndaro, com ele e com outros (dos quais pouco ou

${ }^{1} \mathrm{O}$ mais completo estado do corpus de Baquílides antes da publicação do Papiro de Londres consta da ediçáo de T. Bergk ${ }^{4} 1882$, que reúne, nas páginas 569-588, um total de 62 fragmentos, dos quais apenas 46 conservam, por transmissão indireta, parcelas de texto atribuído ao poeta, num total irrisório de 107 linhas. $\mathrm{O}$ mais longo texto transmitido até entáo era o atual fragmento 4 Maehler (= fr. $13 \mathrm{Bergk}^{4}$ ), um péan aos benefícios da Paz que durante muito tempo foi a jóia dos poucos estudiosos de Baquílides. 
nada sabemos) partilhando o mesmo contexto de patronato e mobilidade artística de finais da época arcaica.

Com o Papiro de Londres - assim ficaria conhecido entre os estudiosos, e assim a ele nos referiremos de ora em diante - se recuperaram, na secção I, as colunas 1 a 22 (odes 1 a 11), na secção II as colunas [23], 24-29 (odes 12 e 13) e, na secção III, as colunas 30-39, parte do livro dos ditirambos (odes 16-19). A tudo isto, acrescente-se um conjunto de cerca de 40 fragmentos menores dispersos que, em ediçóes posteriores, foram gradualmente incluídos no texto conservado do poeta. No entanto, era a última secção a mais valiosa e apreciada do papiro, pois que pela primeira vez era permitido ler na íntegra exemplos textuais de ditirambos - ainda que já de uma fase tardia -, algo de que, até então, apenas tínhamos notícias e escassos fragmentos. De todos os géneros que terão constituído livros isolados nas edições alexandrinas do poeta ${ }^{2}$, apenas o de erotica (poemas de temática amorosa, não necessariamente de índole sexual) náo surge representado pelos fragmentos do Papiro de Londres, sendo os poucos fragmentos que o representam de transmissão indireta.

No que toca à organização dos textos, não é ainda claro o critério que o primeiro escriba do Papiro terá seguido. Com efeito, os epinícios não vêm ordenados segundo o nome do atleta, de acordo com os jogos em que se deu o triunfo ou, sequer, por ordem cronológica das vitórias celebradas. Mais clara parece a ordenação dos seis ditirambos de que se conservam versos, que obedecem a uma ordem alfabética. Assim, ao ditirambo sobre o tema mítico de Idas e

${ }^{2}$ A edição alexandrina de Baquílides conteria epinícios, hinos, peanes, ditirambos, prosodia, partheneia, hyporchemata e erotica. O texto dos $\mathrm{P}$. Oxy. $1361+2081$ (e) e 2362 (= B. frs. 20A-G Maehler) sugere a existência, impossível de confirmar, de um livro adicional de encómios ou cançóes de banquete, o que perfaria um total de nove livros, representativos da versatilidade de Baquílides enquanto poeta coral. 
Marpessa (ode 20), o último do Papiro, seguir-se-iam outros, e conservamos fragmentos ou testemunhos de composiçóes que versariam o tema de Europa (fr. 10), Cassandra (dit. 23), Laocoonte (fr. 9) ou Filoctetes (fr. 7).

Paulatinamente, outros papiros permitiram ler textos atribuídos ao poeta ou com comentários às suas composiçóes (vd. H. Maehler ${ }^{11} 2003$ : 118-121), além de fragmentos de atribuição ainda duvidosa. E assim foi crescendo o corpus de um poeta de quem, há pouco mais de um século, muito pouco se conhecia. Um incremento que, à luz da nova dinâmica que têm conhecido os estudos papirológicos, pode estar ainda por concluir.

\section{Percursos poéticos pelo mundo grego}

As fontes antigas são unânimes em considerar o poeta natural de Iúlis, uma das quatro cidades que integravam a ilha de Ceos (test. 1 e 2). Escassas doze milhas náuticas separavam da Ática esta mais a noroeste ilha das Cíclades, pelo que os contactos seriam frequentes, e é também legítimo acreditar que as reformas culturais empreendidas pelos Pisístratos (de 546 a.C. em diante) aí se tenham feito sentir.

Florescente era a ilha no que toca a sucessos atléticos. Comprova-o a epigrafia, através de uma inscrição datada da transição do século IV para o século III a.C. (IG XII.5), onde constaria o registo dos atletas naturais de Ceos que triunfaram nos quatro Jogos maiores (os Olímpicos, os Píticos, os Nemeus e os Ístmicos), bem como o testemunho do próprio Baquílides, na abertura da ode triunfal que dedica a Lácon, seu compatriota, vencedor no estádio para rapazes em data pouco segura nos Jogos Olímpicos (6.1-9). Essa 
tendência local para as vitórias atléticas parece ter atingido a família do poeta, pois que a Suda (test. 1) informa que o seu avô paterno, de quem herdara de resto o nome, era também ele um atleta premiado. $\mathrm{O}$ ambiente que viu nascer Baquílides terá assim sido o mais propício ao florescimento de um poeta que se haveria de especializar, entre outros géneros, na celebraçáo de triunfos desportivos. Sobrinho pelo ramo materno de um grande poeta, Simónides, dos maiores do seu tempo (test. 1, 2a-b), e neto de um atleta laureado, o seu futuro parecia marcado à nascença. Neste pormenor carregado de determinismo dramático insistiram os primeiros estudiosos que se esforçaram por reconstruir a sua biografia, marcados ainda por um conjunto de tendências de cariz romântico.

Os testemunhos conducentes à data do seu nascimento (test. 4-5) não são concordantes, oscilando em quase duas décadas. No entanto, se assentarmos no lapso temporal de 520-518/517 a.C. - o que de resto é a opinião comum dos principais estudiosos, desfeitas as confusôes das cifras dos cronógrafos antigos -, julgamos conseguir um consenso confortável, com isso ficando evidente que a tradição antiga estava errada (ou pelo menos que o fazia de maneira pouco isenta) ao considerar necessariamente mais jovem do que Píndaro um poeta que tinha, de igual modo, na conta de artisticamente inferior. Aprendendo com o tio - que à data do seu nascimento seria já um poeta talentoso e reconhecido - é natural que Baquílides tenha dado os primeiros passos na terra natal ${ }^{3}$. Mas seria fora da ilha que começaria a adquirir prática e a granjear fama poética, para mais tarde regressar.

${ }^{3}$ É muito provável que se tenha estreado nas celebraçóes em honra de Apolo em Carteia, em cujo choregeion o próprio Simónides havia sido professor. 
Simónides terá passado uma temporada na Tessália, durante a dinastia dos Pisístratos, algures entre 514 (ou mesmo antes) e 490 a.C., data em que regressa a Atenas por ocasiáo das invasôes dos Persas. Muito jovem ainda, é de tradição que Baquílides tenha acompanhado o tio, facto de que restam referências no corpus conservado: a ode 14 para Cleoptólemo da Tessália, provavelmente das composiçóes mais antigas do corpus conservado, a atual ode $14 \mathrm{~B}$ em honra de Aristóteles de Larissa (ainda hoje a capital e maior cidade do distrito da Tessália) e, finalmente, o fragmento 15, que atesta o culto a Atena Itónia, de origem tessálica. Todos estes dados, se insuficientes para sustentar uma residência artística do poeta nessa regiáo, parecem provar que exerceu a sua arte para famílias locais, sendo igualmente possível que, por essas bandas, tenha pela primeira vez contactado com Píndaro, que pela mesma altura aí se teria deslocado. Para a vizinha Macedónia terá também Baquílides exercido o seu ofício poético, como prova o ainda extenso e bem preservado fragmento 20B, dedicado a Alexandre, filho do rei Amintas I, que terá sucedido ao pai algures na década de 90 do século v a.C. e governado sobre a Macedónia durante mais de quarenta anos.

Para Egina, ilha do Golfo Sarónico a sudeste de Atenas, tanto Baquílides quanto Píndaro terão composto em abundância, sobretudo em celebração de vitórias atléticas. As odes 12 e 13 apresentam-nos já um poeta maduro e experiente no género do epinício. No que à ode 13 diz respeito, ela vem dedicada ao egineta Píteas e celebra a mesma vitória que cantou Píndaro (Nemeia 5), poeta que dedicou também a Filácidas, irmão de Píteas, as Ístmicas 5 e 6 . As odes eginetas que de Baquílides conservamos podem situar-se entre os anos de 487 e 480 a.C., mas nada dizem em concreto sobre uma 
estadia do poeta na ilha, já que, no contexto epinício, o envio do poema deve sempre ser considerado.

Os biógrafos tradicionais de Baquílides consideraram que foi no entanto em Atenas que terá tido início o que se considera o seu período de maturidade poética, talento depois confirmado em terras da Magna Grécia. Simónides, ao tempo já o grande poeta grego pela fama que lhe granjeara a celebração da vitória contra os Persas e as muitas vitórias em concursos de ditirambos, deverá ter aí residido durante um largo período de tempo entre 490 e 476 a.C., data em que partiu para a Sicília. Seria por isso natural que tivesse introduzido o sobrinho na elite ateniense e o tivesse feito participar nos grandes concursos de ditirambos, o género poético que, nos textos conservados, mais relaciona o nosso poeta com a pólis dos Atenienses. A. Severyns 1933: 56-69 concluiu, com as devidas reservas, estabelecer os limites deste período ateniense entre os anos de 485-476 a.C., servindo-se para tal de dados que julga poderem datar, em termos relativos, quatro grandes composiçóes de Baquílides, das quais apenas uma (a ode 10) é um epinício. Muito discutida tem sido a datação dos três principais ditirambos do corpus (odes 17, 18 e 19), relacionados de um modo ou de outro com a cidade de Atenas. Os ditirambos $17 \mathrm{e}$ 18 - dedicados à figura de Teseu -, bem assim o ditirambo 19, no qual é protagonista Io, a amada de Zeus metamorfoseada em vaca e perseguida por Hera, fazem sentido se situados em qualquer período dos primeiros quarenta anos do século $\mathrm{v}$ a.C., quando esses mitos - sobretudo o de Teseu, no rescaldo da vitória sobre os Persas - atingiram maior vitalidade na Ática. Não obstante, são muitas as dificuldades em datá-los de maneira definitiva.

$\mathrm{Na}$ Sicília, já os comentadores antigos situavam o pico da carreira de Baquílides, fazendo-o coincidir - mais 
por comodidade do que em obediência a qualquer dado em concreto - com a celebração da vitória olímpica da equipa de jóqueis de Hierão em 468 a.C. (ode 3), ou mesmo com a morte desse tirano, no ano seguinte ou pouco depois. Da convivência do poeta com a tirania siciliana, no entanto, são poucos os testemunhos exteriores à sua obra. Apenas um conjunto de escólios a Píndaro (test. 8a-c) se refere à suposta rivalidade entre ambos os poetas, hipótese que, com as devidas reservas, não nos parece totalmente descabida. Das quatro composiçóes dedicadas a cidadãos sicilianos que conservamos, parece ser a ode 5 a mais antiga, composta por ocasião da vitória de Hierão na corrida de carros de quatro cavalos em Olímpia, em 476 a.C. Hierão teria conseguido três vitórias nesses jogos, uma na quadriga, outras duas na corrida individual de cavalos (a modalidade em causa na ode 5), estas últimas em 476 e 472 a.C.

Pouco tempo depois parece Baquílides ter ofertado a Hierão um novo canto, desta feita em género de encómio ou canção de mesa (fr. 20C). Constitui a referência ao envio para o Etna (vv. 5-6) um dos principais dados que permitem datar este poema. Com efeito, Hierão havia fundado essa cidade em 476 a.C., o que de imediato oferece à composição um terminus post quem. Igualmente datável com segurança é o epinício 3, que nos coloca perante o expoente máximo da carreira de Baquílides, como já defendiam os comentadores antigos. Comemorativo do triunfo de Hierão na corrida de carros de cavalos dos Jogos Olímpicos, os testemunhos antigos são claros em datá-lo da 78 Olimpíada (468 a.C.). Diversas hipóteses sugeriram os estudiosos, ao longo do tempo, para explicar a não contratação de Píndaro para esta celebração, que além de importante seria a derradeira. Não sendo nenhuma delas segura, parece certo que nesse momento 
Hierão preferiu de facto os serviços de Baquílides, seja pela indisponibilidade de Píndaro, seja simplesmente por preferir a arte do poeta de Ceos, hipótese para alguns constrangedora mas que deve, no mínimo, ser colocada sem pudor.

Baquílides compôs também um número considerável de odes para a terra natal, não sendo forçoso considerá-las produto de um enfraquecimento de génio e força poéticos, como pretendia A. Severyns 1933: 97, que atribuía ao terceiro capítulo da sua biografia de Baquílides, dedicado ao período pós-siciliano, já de si expressivo título de "declínio». Deste período, em que parece correto situar as últimas composiçóes poéticas de Baquílides, apenas temos como certo o ano de composição das odes 6 e 7 (452 a.C.). Das restantes, nenhum dado concreto nos permite situá-las de forma conclusiva no tempo. Não obstante, parece pacífico que as odes 1, 2, 6, 7 e 8 datam, de facto, desse tempo, algures depois do período mais ativo de produçáo para a Sicília, conseguindo, deste modo, um terminus post quem correspondente ao ano de 465 a.C., se admitirmos que, por essa altura, o poeta terá abandonado a Magna Grécia.

Mas há ainda que considerar um provável exílio de Baquílides no Peloponeso, a que apenas Plutarco (test. 6) alude, num texto que parte do pressuposto de que o exílio do poeta se ficou a dever a uma qualquer sentença de expulsão, provavelmente motivada por revoltas democráticas em Ceos que teriam tornado incómoda a permanência de Baquílides, um servidor das Musas mas também de conhecidos tiranos. No que ao lapso temporal desse exílio diz respeito, R. C. Jebb 1905: 25 preferiu considerar que ele ocorreu depois de 452 a.C., data em que, como vimos, o poeta estaria ainda em Ceos para celebrar a vitória de Lácon. Mas esta hipótese assentava no princípio, ele próprio pleno de reservas, de 
que a vida de Baquílides se havia prolongado até ao início da Guerra do Peloponeso (431 a.C.), teoria atualmente abandonada. Por isso os estudiosos foram apontando datas mais recuadas para esse exílio, anteriores ao ano de 452 a.C. A outro nível, R. C. Jebb 1905: 25-26 procedeu ao elenco do que considerava serem os reflexos da produção poética desse período. Destacamos dois momentos principais: a ode 9, o único epinício dedicado a um atleta do Peloponeso, mais propriamente a Automedes de Fliunte, e o ditirambo 20, que a epígrafe do Papiro de Londres diz claramente ter sido composto para que o apresentassem os Espartanos num qualquer festival público. Não obstante, nenhum destes textos é datável com segurança, da mesma maneira que não é correto assumir que um poeta exilado apenas estivesse autorizado a compor para a zona geográfica e política em que se encontrava.

Dois testemunhos muito tardios dos cronógrafos Eusébio (test. 4e) e Sincelo (test. 4d) - o primeiro dos séculos III e IV e o segundo do século IX, ambos da nossa era - parecem prolongar a vida do poeta até aos primeiros anos da Guerra do Peloponeso (431 a.C.). A. Körte 1918: 144-145 considerava pouco provável a fixação de um limite tâo tardio para a vida de Baquílides (década de 30 do século $\mathrm{V}$ a.C.), argumentando que, a ser assim, teria deixado marcas mais evidentes na literatura da segunda metade desse século, tấo importante que fora em Atenas, da mesma forma que teria por certo sido incluído nas listas de presbuteroi ( velhos»), de que tanto gostavam os Gregos, como foi o caso de Simónides. Como tal, constitui tendência atual admitir como provável a data de 452-451 a.C. para a morte de Baquílides, bem assim os anos de 518-517 para o seu nascimento, hipótese que, não sendo mais do que orientadora, nos parece 
a mais plausível, na medida em que aceitar a década de 30 (ou os inícios da década de 20) para a sua morte implicaria uma cedência maior: considerar um silêncio de pelo menos duas décadas quanto à sua vida e obra.

Do que até agora se disse pode concluir-se mais a falta de certezas do que a possibilidade de consensos. Com efeito, são muito tardios os testemunhos biográficos diretos, e é quase sempre pela discussão das circunstâncias temporais e indicações internas de determinados textos conservados que a biografia do poeta pode, passo a passo, ir sendo reconstruída. Os dados possíveis de colher no corpus conservado, mais do que os testemunhos externos, parecem provar que, à semelhança de Simónides ou Píndaro, também Baquílides exerceu a sua atividade pelos principais focos culturais do mundo grego, privando com as grandes famílias da Tessália, Egina, Atenas e da Magna Grécia, não descurando, com isso, as glórias atléticas da ilha natal que, a acreditar no testemunho de Plutarco (test. 6), a dada altura lhe terá virado as costas, condenando-o ao exílio. Sendo provável que a influência de Simónides, seu tio, tenha marcado de forma decisiva os inícios da sua carreira, cedo terá Baquílides conseguido autonomia suficiente para, exemplo máximo, lograr obter na Sicília a preferência de Hierão contra a feroz concorrência de Píndaro.

\section{TRANSMISSÃO E APROXIMAÇÕES CRÍTICAS}

Ignoramos as circunstâncias em que os poemas de Baquílides terão pela primeira vez passado a escrito, e mesmo durante os séculos V e IV a.C., como bem concluiu R. C. Jebb 1905: 74, «ele náo é mencionado em nenhuma obra conservada». Não obstante, o mesmo estudioso tende a 
reconhecer em autores clássicos ecos dos seus poemas, o que, quanto muito, prova uma influência não reconhecida e leva a supor que circulassem cópias das suas principais composiçóes poéticas. A outro nível, sabemos da frequência com que este tipo de composiçôes corais (epinícios e ditirambos, sobretudo) era alvo de reposiçóes, o que, aliado ao facto de as primeiras apresentaçóes terem lugar, por norma, em festivais públicos muito frequentados, pode iluminar as razóes que tornariam um poeta famoso, e mesmo oralmente conhecido e citado de memória.

Foi a partir da Época Alexandrina que Baquílides começou a ser referido, citado e admirado sob os mais diversos pontos de vista: mitológico, rítmico ou estilístico ${ }^{4}$. É muito provável de Aristófanes de Bizâncio, no século III a.C., tenha elaborado uma edição do texto conservado, agrupando-o por géneros e mesmo restituindo-o à métrica original (apud H. Maehler 2004: 27). Pseudo-Amónio, no século IV d.C., alude a um comentário aos epinícios que teria sido elaborado por Dídimo, autor cujo floruit a tradição situa por volta do ano 30 da nossa era. Referido pelos escoliastas de Homero, Hesíodo, Aristófanes, Apolónio de Rodes e Calímaco, é no entanto nos comentários aos epinícios pindáricos (test. 8a-c) que vamos encontrar um juízo no global redutor da sua poesia, pois que está em causa compará-la com a do grande poeta tebano. Mais do que fontes fidedignas ou avaliaçóes credíveis, estes textos

${ }^{4}$ Sobre a presença de Baquílides na Antiguidade vd. R. La Clara, «La fama di Bacchilide presso gli antichi», RSA 10 (1906) 514-536. Útil e válido - porquanto é mais amplo e chega ao século vi da nossa era - é ainda o elenco de R. C. Jebb 1905: 75-76, bem como esse outro, mais recente e completo, de F. García Romero 1988: 49-52. Também D. L. Cairns 2010: 12-15 procedeu a esse elenco, realçando o que considera serem provas inequívocas da inspiração no poeta de nomes como Sófocles, Eurípides, Aristófanes, Calímaco e Horácio, entre outros. 
são uma excelente amostra do crédito que o poeta recebeu durante séculos consecutivos, ofuscado a toda a hora pelo gigantismo - em si mesmo justificado - de Píndaro. Não cabendo a propósito uma multiplicação de exemplos, importa referir que foi sobretudo à volta da figura de Hierão que os comentadores antigos mais insistiram no tema da rivalidade entre os dois poetas, pois que já eles seriam herdeiros da tradição segundo a qual foi na Sicília que Baquílides conseguiu o mais alto nível de fama.

Incontornável é também o texto de Pseudo-Longino (test. 9a), já do século III da nossa era, que parece inaugurar uma tendência que se prolongaria até bem tarde, a de estudar o poeta de Ceos sempre em comparaçáo com o seu rival tebano. $\mathrm{O}$ autor do tratado procura averiguar que autor é mais grandioso na poesia e na prosa, dividindo toda a literatura grega em géneros (épica, elegia, lírica, tragédia e retórica) e apontando, para cada um deles, um autor paradigmático 5 . O que se pretende provar é que nem sempre a fama coincide com o real mérito de um poeta, afirmando-se por outro lado - e aqui parece Baquílides sair prejudicado - que «a perfeição corre sérios riscos de se tornar trivialidade». E parece essa perfeição formal, o critério de valorização em causa, coincidir com a infalibilidade no cinzelar das palavras atribuída a Baquílides, o que nos leva a supor que este juízo crítico assentasse sobretudo em questóes métricas e rítmicas. Assim, pese embora a preferência canónica por Píndaro, não deixa de ser curioso que já o anónimo autor do tratado reconheça à arte de Baquílides

${ }^{5}$ Há que referir que, até ao século XIx, de todos os autores considerados canónicos no tratado em apreço se conservava grande quantidade de texto, à exceção de um, ao passo que, dos outros - os que servem de comparação como menos geniais - apenas três eram conhecidos por mais do que escassos fragmentos. 
uma maior fluência, um estilo mais fácil e agradável, o que pode ser confirmado, no século IV d.C. pela alusão de Amiano Marcelino (fr. 38) ao prazer que da sua leitura retirava o imperador Juliano. O impressionismo dos versos de Baquílides, o uso hábil que faz do léxico e da semântica com vista a conseguir descriçóes fortes e marcadas por um cromatismo evidente, a adaptação à forma lírica dos temas e do léxico da épica, o abundante e polissignificativo uso dos epítetos (tantas vezes de sua forja pessoal) - estas algumas das valências reconhecidas atualmente à sua arte poética e que parecem estar já implícitas no sintagma egregius pictor («pintor requintado»), do texto de Amiano.

É justo concluir que dois fatores marcaram o reconhecimento de Baquílides, desde a Antiguidade e, sobretudo, na modernidade, tendo o poeta que esperar pela segunda metade do século xx para que a sua arte colhesse leituras descomprometidas e apostadas na isenção: a sombra que lhe fizeram os vultos de Simónides e Píndaro, com especial destaque para o último ${ }^{6}$, e a precária conservação dos seus textos, quando comparados - e aqui sim há que compará-los - com os do poeta tebano. E que esta segunda condicionante esteja na direta dependência da primeira, ninguém parece ter dúvidas.

${ }^{6}$ Para uma síntese das aproximaçóes críticas ao texto de Baquílides vd. I. L. Pfeijffer, S. R. Slings 1999: 7-15. Aí se considera, oportunamente, uma fase da aproximação hermenêutica a Baquílides em que o poeta era visto como um autêntico appendix a Píndaro, para só mais tarde se passar a valorizar o que já Pseudo-Longino valorizava: a sua arte narrativa. 


\section{Bibliografia}

Além dos trabalhos mencionados nas introduçóes e nas notas, foi nosso intuito fornecer uma lista atualizada do que julgamos serem os principais e mais importantes estudos sobre a poesia de Baquílides e os assuntos com ela relacionados. De fora ficam os trabalhos que se centram sobre aspetos de pormenor, úteis essencialmente a filólogos e outros especialistas do poeta.

\section{Ediçóes, traduçóes e comentários}

Bergk, T. ( $\left.{ }^{4} 1882\right)$, Poetae Lyrici Graeci III. Leipsig.

Blass, F. $\left({ }^{1} 1898,{ }^{2} 1899,{ }^{3} 1904,{ }^{4} 1912\right)$, Bacchylidis carmina cum fragmentis. Leipzig.

Cairns, D. L. (2010), Bacchylides: five epinician odes (3, 5, 9 , 11, 13). Cambridge.

Campbell, D. A. (1992), Greek lyric IV. Cambridge, Mass.

Eichthal, E., Reinach, T. (1898), Bacchylide. Poèmes choisis, traduits en vers... Illustrations d'après des oeuvres d'art contemporaines du poète. Paris.

Fagles, R. (1961), Bacchylides. Complete poems. New Haven.

Festa, N. (1898, repr. 1916), Bacchilide. Odi e frammenti. Firenz.

García Romero, F. (1988), Baquilides. Odas y fragmentos. Madrid.

Irigoin, J., et alii (1993), Bacchylide. Dithyrambes, épinicies, fragments. Paris. 
Jebb, R. C. (1905), Bacchylides. The poems and fragments. Cambridge.

Kenyon, F. G. (1897), The Poems of Bacchylides. London.

Maehler, H. (1982), Die Lieder des Bakchylides I (2 vols.). Leiden.

Maehler, H. (1997), Die Lieder des Bakchylides II. Die Dithyramben und Fragmente (2 vols.). Leiden.

Maehler, H. ( $\left.{ }^{11} 2003\right)$, Bacchylidis carmina cum fragmentis. Leipzig.

Maehler, H. (2004), Bacchylides. A selection. Cambridge.

McDevitt, A. (2009), Bacchylides: the Victory Poems. London.

Slavitt, D. R. (1998), Epinician odes and dithyrambs of Bacchylides. Philadelphia.

Snell, B. $\left({ }^{5} 1934,{ }^{6} 1949,{ }^{7} 1958,{ }^{8} 1961\right)$, Bacchylidis carmina cum fragmentis. Leipzig.

Snell, B., Maehler, H. ('1970), Bacchylidis carmina cum fragmentis. Leipzig.

\section{Estudos}

Arnould, D. (2001), "Quand Thésée voyait rouge: à propos du dithyrambe IV de Bacchylide», REG 114.1: 222227.

Athanassaki, L., Bowie, E. edd. (2011), Archaic and Classical Choral Song: performance, politics and dissemination. Berlin. 


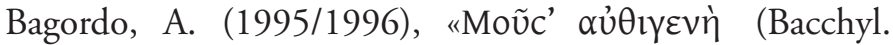
2.11)», Glotta 73: 137-141.

Bagordo, A., Zimmermann, B. (2000), Bakchylides: 100 Jahre nach seiner Wiederentdeckung. Münch.

Balasch, M. (1971), "La teoría poética de Baquílides», Helmantica 69: 369-386.

Balasch, M. (1972), "La concepción del hombre en Baquílides», BIEH 6: 35-46.

Barron, J. P. (1980), «Bacchylides, Theseus and a woolly cloak», BICS 27: 1-8.

Bernardini, P. A. (1980), «Esaltazione e critica del atletismo nella poesia greca dal VII al V secolo a.C. Storia di un'ideologia», Stadion 6: 81-111.

Bernardini, P. A. (1988), Lo Sport in Grecia. Roma, Bari.

Bernardini, P. A. (1992), «La storia dell'epinicio: aspetti socio-economici», SIFC 10.2: 965-978.

Bernardini, P. A. (2000), «La ode di Argeo di Ceo e del padre Pantide nell'Epinicio 1 di Bacchilide», in Bagordo, A., Zimmermann, B. (2000) 131-146.

Bernardini, P. A. (2005), «Trittico bacchilideo: epinicio 3; ditirambo 1 (15); ditirambo 3 (17)», QUCC 79.1: 1128.

Blass, F. (1898), «Bakchylides' Gedicht auf Pytheas von Aigina», RhM 53: 283-307. Repr. W. H. Calder, J. Stern edd. (1970) 364-390.

Bowra, C. M. (1938), "The daughters of Asopus», Hermes 73.2: 213-221. 
Bowra, C. M. (21961), Greek Lyric Poetry from Alcman to Simonides. Oxford.

Brannan, P. T. (1972a), «Bacchylides' fourth ode», CF 26: 175-184.

Brannan, P. T. (1972b), «Hieron and Bacchylides. An analysis of Bacchylides' fifth ode», CF 26: 185-278.

Brannan, P. T. (1973), «Bacchylides' third ode», CF 27: $187-$ 229.

Burkert, W. (1985), «Das Ende des Kroisos: Vorstufen einer Herodoteischen Geschichtserzählung», Catalepton: 4-15.

Burnett, A. P. (1985), The Art of Bacchylides. Cambridge, Mass.

Burnett, A. P. (2005), Pindar's songs for young athletes of Aigina. Oxford.

Cairns, D. L. (1997), «Form and meaning in Bacchylides' fifth ode", Scholia 6: 34-48.

Cairns, D. L. (2005), «Myth and the polis in Bacchylides' eleventh ode», JHS 125: 35-50.

Cairns, D. L. (2011), «The principle of alternation and the tyrant's happiness in Bacchylidean epinician", SO 85: $17-32$.

Calame, C. (1999), «Tempo del raconto e tempo del rito nella poesia greca: Bacchilide tra mito, storia e culto", QUCC 62.2: 63-83.

Calame, C. (2011), «Enunciative fiction and poetic performance. Choral voices in Bacchylides' 
Epinicians», in Athanassaki, L., Bowie, E. edd. 2011: 115-138.

Calder III, W. M., Stern, J. edd. (1970), Pindaros und Bakchylides. Darmstadt.

Carey, C. (1980), «Bacchylides experiments: ode 11", Mnemosyne 33: 225-43.

Carey, C. (1989), «The performance of the victory ode», $A J P$ 110: 545-565.

Carey, C. (1991), «The victory ode in performance: the case for the chorus», CPh 85: 192-200.

Carey, C. (1999), "Ethos and pathos in Bacchylides», in Pfeijffer, I. L., Slings, S. R. edd. (1999) 17-29.

Carson, A. (1984), «The burners: a reading of Bacchylides' third epinician ode», Phoenix 38.2: 111-119.

Catenacci, C., Di Marzio, M. (2004), «Il galo di Urania (Bacchilide, Epinicio 4)», QUCC 76.1: 71-89.

Cornelius, F. (1957), «Kroisos», Gymnasium 64: 346-347.

Costanza, S. (2010), «Artemide e le Pretidi da Bacchilide (ep. 11) a Callimaco (b. 3, 233-236)», ZPE 172: 1-21.

Cummins, M. F. (1993), Myth in Pindar and Bacchylides: five studies in narrative pattern and convention. $\mathrm{PhD}$ diss. UMI.

Demarque, M. C. (1966), Traditional and individual ideas in Bacchylides. PhD diss. Illinois.

Dowden, K. (1989), Death and the Maiden. Girl's initiation rites in Greek mythology. London. 
Duchemin, J. (1974), «L'usage comparé du mythe chez Bacchylide et chez Pindare», BIFG 1: 180-193.

Dumortier, J. (1937), «De quelques associations d'images chez Bacchylide», Mélanges offerts à A.-M. Desrousseaux. Paris: 151-158. Repr. Calder III, W. M., Stern, J. 1970: 413-420.

Errandonea, I. (1927), «Deianira uere $\triangle$ HI-ANEIPA», Mnemosyne 55: 145-164.

Evans, J. A. S. (1978), «What happened to Croesus?», CJ 74.1: 34-40.

Farnell, L. R. (1898), "Archaeological notes on Bacchylides», CR 12.7: 343-346.

Fearn, D. (2003), «Mapping Phleious: politics and mythmaking in Bacchylides 9", CQ 53. 2: 347-367.

Fearn, D. (2007), Bacchylides. Politics, performance, poetic tradition. Oxford.

Fearn, D. ed. (2011), Aegina: contexts for choral lyric poetry. Myth, history, and identity in the fifth century $B C$. Oxford.

Fearn, D. (2012), "Bacchylidean Myths», in Agocs, P. et alii edd., Reading the Victory Ode. Cambridge: 321344.

Ferreira, L. N. (2008), «Io e Marpessa - uma análise dos ditirambos XIX e Xx de Baquílides», Humanitas 60: 57-73.

Ferreira, L. N. (2013), Mobilidade Poética na Grécia Antiga. Uma leitura da obra de Simónides. Coimbra. 
Finn, J. K. (1980), A Study of the elaboration and function of epinician conventions in selected odes of Bacchylides. $\mathrm{PhD}$ diss. Duke.

Galiart, L. H. (1912), Beiträge zur Mythologie bei Bakchylides. Die Meleagrossage. Die Herakles-Deianeirasage. Die Zeus-Iosage. Freiburg.

García Romero, F. (1987), Estructura de la Oda Baquilidea. Estudio composicional y métrico. PhD diss. (2 vols.). Madrid.

García Romero, F. (1992), Los Juegos Olímpicos y el Deporte en Grecia. Barcelona.

García Romero, F. (1996), «Metafore agonistiche nelle odi di Bacchilide», QUCC 54.3: 55-66.

García Romero, F. (2002), «La función del mito en el epinicio», in López Férez, J. A., ed., Mitos en la literatura griega arcaica y clásica. Madrid: 159-174.

Garner, R. (1992), "Countless deeds of valour: Bacchylides 11», CQ 42.2: 523-525.

Gelzer, T. (1985), «Mousa Authigenes: Bemerkungen zu einem Typ Pindarischer und Bacchylideischer Epinikien", MH 42: 95-120.

Gentili, B. (1953), «I tripodi di Delfi e il carme III di Bacchilide», PP 8: 199-208.

Gentili, B. (1958), Bacchilide. Urbino.

Giesekam, G. J. (1976-7), "The portrayal of Minos in Bacchylides 17», in Cairns, F. ed., Papers of Liverpool Latin Seminar. Liverpool: 237-252. 
Goldhill, S. (1983), «Narrative structure in Bacchylides 5», Eranos 81: 65-81.

González de Tobia, A. M. (2000), «La poesía de Baquílides como proyección de una 'APETA inconfundible», Synthesis 7: 149-163.

González de Tobia, A. M. (2007), «Lenguage, discurso y civilización en Baquílides 11", in González de Tobia, A. M. ed., Lenguage, discurso y civilización. De Grecia a la Modernidad. Mexico: 99-116.

Hamilton, R. (1974), Epinikion. General form in the odes of Pindar. Paris.

Harrison, J. E. (1898), «Notes archaeological and mythological on Bacchylides», CR 12.1: 85-86.

Hemmerdinger, B. (1979), «Bacchylide. A propos de l'histoire du texte au Moyen Âge», ByzF 6: 79-82.

Hurst, A. (1983), «Temps du récit chez Pindare (Pyth. 4) et Bacchylide (11)», MH 40: 154-168.

Jesus, C. A. M. (2008a), A Flauta e a Lira. Estudos sobre poesia grega e papirologia. Coimbra (esp. pp. 71-86).

Karachalios, F. (2009), «Mythical inversions and history in Bacchylides 5», PSWPC (Princeton/ Stanford Working Papers in Classics): 12-28.

Kirkwood, G. M. (1966), «The narrative art of Bacchylides», in Wallach, L., Caplan, H. edd., The Classical Tradition: Literary and Historical Studies in Honor of Harry Caplan. Ithaca: 98-114.

Körte, A. (1918), «Bacchylidea», Hermes 53: 113-147. 
Lefkowitz, M. R. (1969), «Bacchylides' ode 5: imitation and originality», HSCP 73: 45-96.

Lefkowitz, M. R. (1976), The Victory Ode. An introduction. Park Ridge.

Lens Tuero, J. (1999), «El fin de Creso en Baquílides», in López Férez, J. A. ed., Desde los poemas homéricos hasta la prosa griega del siglo IV d.C. Veintisés estudios filológicos. Madrid: 111-124.

Lourenço, F. (2009), "Lírica coral e monódica: uma problemática revisitada», Humanitas 61: 19-29.

Mallinger, L. (1898), "Bacchylide avant et après 1896", Musée Belge 2: 188-209.

Maravela, A. (2011), "The athlete's 'happiness': eudaimonia in archaic Greek epinicians», SO 85: 33-51.

Marquez Guerrero, M. A. (1992), Las Gnomai de Baquilides. Sevilha.

Meiser, O. (1904), Mythologische Untersuchungen zu Bakchylides. PhD diss. München.

Montepaone, C. (1986), «L'apologia di Alexidamos, 'l'avventura del cavaliere'», Metis 1: 219-235.

Nagy, G. (2011), «A second look at the poetics of reenactment in ode 13 of Bacchylides", in Athanassaki, L., Bowie, E. edd. 2011: 173-206.

Norsa, M. (1941), "Due frammenti fiorentini del papiro di Bacchilide P. Brit. Mus. 733”, ASNP 10: 155-163.

Paratore, E. (1956), «Bacchilide e Virgilio», WS 69: 289296. 
Pavese, C. O. (1973/1974), «Gli epinici di Bacchilide», $A I V$ 132: 299-328.

Péron, J. (1978), «Les mythes de Crésus et de Méléagre dans les odes III et v de Bacchylide», REG 91: 307-339.

Pfeijffer, I. L. (1994), «The image of the eagle in Pindar and Bacchylides», CPh 89.4: 305-317.

Pfeijffer, I. L. (1995), «The date of Pindar's fifth Nemean and Bacchylides' thirteenth ode», CQ 45.2: 318-332.

Pfeijffer, I. L. (1999a), «Bacchylides' Homer, his tragedy \& his Pindar», in Pfeijffer, I. L., Slings, S. R. edd 1999: 43-60.

Pfeijffer, I. L., Slings, S. R. edd. (1999), One hundred years of Bacchylides: proceedings of a colloquium held at the Vrije Universeieit Amsterdam. Amsterdam.

Pieper, G. W. (1969), Unity and poetic tecnique in the odes of Bachylides. PhD diss. Illinois.

Power, T. (2000), "The parthenoi of Bacchylides 13", HSCP 100: 67-81.

Resinski, R. (2000), «Deianeira's neck in Bacchylides, ode 5", Helios 27. 1: 3-14.

Ribeiro Ferreira, J. (2000), «A heroização do vencedor na poesia grega», in Oliveira F., coord., $O$ Espirito Olímpico no Novo Milénio. Coimbra: 45-55.

Riemer, P. (2000), «Die 'ewige Deianeira'», in Bagordo, A. e Zimmermann, B. edd. 2000: 169-182.

Robert, C. (1898), «Theseus und Meleagros bei Bakchylides», Hermes 33: 130-159. 
Robins, E. (1997), «Bacchylides», in Gerber, D. E. ed., $A$ Companion to Greek Lyric Poets. Leiden, New York, Köln: 278.

Rocha Pereira, M. H. (2000), "Os vencedores dos Jogos: a glória na arte», in Oliveira, F. coord., O Espirito Olímpico no Novo Milénio. Coimbra: 23-43.

Sbordone, F. (1965), Lezioni di letteratura greca su Bacchilide e Pindaro. Napoli.

Schmidt, D. A. (1987), «The performance of Bacchylides Ode 5", CQ 37.1: 20-23.

Schmidt, D. A. (1990), "Bacchylides 17 - paean or dithyramb?», Hermes 118.1: 18-31.

Schmidt, D. A. (1999), "An unusual victory list from Keos: $I G$ XII.5.608 and the dating of Bakchylides", JHS 119: $67-85$.

Schober, C. (1939), Sage und Mythos bei Bakchylides. Phd diss. Graz.

Seaford, R. (1988), «The eleventh ode of Bacchylides: Hera, Artemis, and the absence of Dionysos», JHS 108: 118-136.

Segal, C. (1971), "Croesus on the pyre: Herodotus and Bacchylides», WS 84.5: 39-51.

Segal, C. (1976), «Bacchylides reconsidered: epithets and the dynamics of lyric narrative», QUCC 1976 22: 99-130.

Segurado e Campos, J. A. (1996), «Baquílides 11: arquitectura de um epinício", Classica 21: 7-53. 
Severyns, A. (1933), Bacchylide. Essai biographique. Lièje, Paris.

Slatter, C. (1994), «Heracles, Deianeira, and Nessus: reverse chronology and human knowledge in Bacchylides 16», AJP 115.3: 337-349.

Smith, A. H. (1898), «Illustrations to Bacchylides», JHS 18: 267-280.

Sousa e Silva, M. F. (2008), "Epinício 11 de Baquílides a Alexidamo de Metaponto. Luta de rapazes, Jogos Píticos», Humanitas 60: 45-55.

Steffen, W. (1961), «Bacchylides' fifth ode», Eos 51: 11-20.

Stern, J. (1965), "Bestial imagery in Bacchylides' ode 11», GRBS 6.4: 275-282.

Stern, J. (1967), «The imagery of Bacchylides' ode 5», GRBS 8.1: 35-43.

Stern, J. (1970), "An essay on Bacchylidean criticism», in Calder III, W. M., Stern, J. edd. 1970: 290-307.

Stuart Jones, H. (1898), «Bacchylides and the fate of Croesus», CR 12.1: 84-85.

Suárez de la Torre, E. (2000), «Bemerkungen zu den Mythen bei Bakchylides», in Bagordo, A. e Zimmermann, B. edd. 2000: 226-231.

Sullivan, S. D. (1991), "The wider meaning of psyche in Pindar and Bacchylides», SIFC 9.2: 163-183.

Svarlien, D. A. (1995), "Reversal of imagery and values in Bacchylides 3 and 5», QUCC 50.2: 35-45. 
Tarditi, G. (1989), «La gratitudine degli dei: l'O $\Lambda \mathrm{BO}$ di Ierone e la vicenda del vecchio Creso (Bacch. Epin. 3)», RFIC 117.3: 276-285.

Tarkow, T. A. (1978), «Dependence on externals: the role of animals in Bacchylides' ode 5", RSC 26: 379-387.

Tedeschi, A. (1985), "L'invio del carme nella poesia lirica arcaica: Pindaro e Bacchylide», SFIC 78: 29-54.

Thomas, R. (2007), «Fame, memorial, and choral poetry: the origins of epinikian poetry - an historical study», in Hornblower. S., Morgan, C. edd., Pindar's Poetry, Patrons, and Festivals. From Archaic Greece to the Roman Empire. Oxford: 141-166.

Townsend, E. D. (1956), Bacchylides and lyric style. PhD diss. Bryn Mawr.

Vian, F. (1965), «Mélampous et les Proitides», REA 1-2: $25-$ 30.

Villarrubia Medina, A. (1990), «Minos y Teseo. Análisis de la oda Xvir de Baquílides», Habis 21: 15-32.

Villarrubia Medina, A. (1991), «Los similes en la poesía de Baquílides», Habis 22: 81-96.

Villarrubia Medina, A. (1993), "Algunas notas sobre los epinicios de Baquilides a proposito de la oda 5", Habis 24: 11-18.

Wilamowitz-Moellendorff, U. von (1898), «Rezenzion von: The Poems of Bakchylides», Göttingische Gelehrte Anzeigen 160: 125-160. Repr. in Calder III, W. M., Stern, J. edd. 1970: 322-363. 
Wilamowitz-Moellendorff, U. von (1922, repr. 1966), Pindaros. Berlin, Weidmann.

Williams, D. (1987), "Aegina, Aphaia-Tempel XI: the pottery from the second limestone temple and the later history of the sanctuary", $A A$ : 629-680.

Wind, R. (1964), Bacchylides' odes 5, 17 and 18. A study in point of view. PhD diss. Iowa.

Woloch, M. (1963), "Athenian trainers in the Aeginetan odes of Pindar and Bacchylides», CW 56.4: 102-104, 121. 
(Página deixada propositadamente em branco) 
Odes e Fragmentos

\author{
BAQUÍlIDES
}


(Página deixada propositadamente em branco) 


\section{EPINÍ́cios}


(Página deixada propositadamente em branco) 


\section{Odes 1 e 2}

É possível que o primeiro escriba do Papiro de Londres tenha decidido abrir o rolo dos epinícios com estas duas composiçóes de forma a prestar homenagem à pátria do poeta. Se isto náo é seguro - desde logo porque, a ser assim, o natural seria que se seguissem as odes 6,7 e 8 , também dedicadas a atletas de Ceos -, tampouco conseguiram ainda os estudiosos apurar os critérios de organização dos epinícios no Papiro, pois que esta não é cronológica ou geográfica, nem sequer obedece à importância relativa do triunfo celebrado a ser válida a última hipótese, o rolo começaria, por exemplo, pela ode 3 .

A. Severyns 1933: 103-105 concluiu ser plausível datar as odes 1 e 2 entre os anos de 464-454 a.C., preferindo, como proposta orientadora, o ano de 456 a.C. Posteriormente, H. Maehler 1982: 3-4 mostrou a preferência pelos anos 454452 a.C., ao passo que P. A. Bernardini 2000: 132-134 se fez arauto de uma datação um pouco anterior (c. 462460). Finalmente, na sua recente tradução comentada dos epinícios de Baquílides, A. McDevitt 2009: 69-70 entende que os limites possíveis para a datação das odes 1 e 2 são os anos de 458-452 a.C.

Perdida a epígrafe do epinício 1 , a ode 2 apenas regista, à cabeça, um genérico tô autô ("Ao mesmo"), em nada contribuindo para a resoluçáo do problema. Mas, à exceção de F. G. Kenyon 1897: 12-13, os estudiosos não tiveram dúvidas em considerar que o destinatário de ambas composições seria o jovem Argeu, filho de Pântides (1.142, 
147; 2.4-5, 14), habitante em Ceos (2.2) e vencedor nos Jogos Ístmicos. Trata-se, assim, do mesmo atleta que numa inscrição epigráfica encontrada em Iúlis (na ilha de Ceos) surge como vencedor no Istmo (linha 15) e em Nemeia (linha 26), em ambos os casos na categoria de jovens (linha 26). Por esclarecer ficava apenas a prova em causa, que poderia ser tanto o pancrácio como o pugilato, dúvida a que os especialistas têm respondido com a segunda alternativa, confiados na propensão para essa modalidade dos atletas de Ceos, segundo exprime o próprio Baquílides (6.7). Mais recentemente, D. Schmidt 1999: 80, conciliando as referências internas dos poemas com a sua interpretação da inscrição de Iúlis, tem por mais prudente considerar que se tratava da luta ou mesmo do pentatlo, preferindo, a título pessoal, a primeira hipótese. É tendência atual - embora o assunto continue a ser de extrema polémica - considerar que o primeiro poema terá sido executado em Ceos, em celebraçấo do regresso a casa do vencedor, ao passo que o segundo, mais breve e sem mito, poderia ter sido apresentado no Istmo, imediatamente após o triunfo.

Acredita-se hoje que a ode 1 , na redação original, contaria com oito tríades completas (oito sequências métricas uniformes de 23 versos cada, 8 na Estrofe, 8 na Antístrofe e 7 no Epodo), das quais apenas as últimas duas (vv. 139 sqq.) estáo praticamente completas, apesar de o texto se apresentar bastante legível a partir do Epodo quinto (vv. 111 sqq.) e, desse modo, ser possível ler praticamente na íntegra a parte final da narrativa dos Telquines (divindades tectónicas locais), que teria começado cedo (v. 19?). A aceitar a reconstrução do poema inicialmente proposta por F. Blass ${ }^{3} 1904$ : LVI-LVII, a secção mítica do epinício, versando sobre um único tema (cf. infra, nota 6), estender-se-ia por cerca de 120 versos (vv. 
19-139), dos quais temos, ainda hoje, muitas dificuldades em ler os primeiros 92. Por entre as lacunas textuais percebese que a ode obedece a um esquema tripartido comum com mito central, apresentando como partes fundamentais: a) um proémio, provavelmente seguido de um primeiro elogio do vencedor, b) uma extensa narração mítica, neste caso de um único mito (vv. 19-139?), e o regresso ao momento presente, com c) os derradeiros elogios do atleta e da sua família (vv. 140-158) e as sentenças finais (vv. 159-184). 


\section{1. [a Argeu de Ceos, pelo pugilato ${ }^{\mathrm{I}}$ de rapazes (?) NOS Jogos ÍstMicos]}

Deusas da lira famosa, filhas de Zeus Estrofe 1 soberano das alturas e ainda virgens, ... Piérides ${ }^{2}$, e entrelaçai [hinos imortais], para [glorificar ... o que da terra do Istmo foi o fundador], do prudente... Nereu o genro ${ }^{3}$,

... e de uma ilha ${ }^{4}$ bem Antistrofe 1 guarnecida], onde

\section{Ó portas da brilhante ilha}

14 de Pélops ${ }^{5}$, obra dos deuses!

(faltam dois versos)

(faltam dois versos)

Epodo 1

${ }^{1} \mathrm{Vd}$. texto de apresentaçáo. $\mathrm{O}$ texto conservado apenas deixa claro que se trata de uma modalidade de luta.

${ }^{2}$ Outra designação para as Musas, que teriam nascido na Piéria.

${ }^{3}$ Poséidon, aqui invocado como divindade tutelar dos Jogos Ístmicos, era esposo de Anfitrite (cf. ode 17) e, como tal, genro de Nereu.

${ }^{4}$ Ceos, pátria do vencedor e do poeta.

${ }^{5}$ O Istmo de Corinto, lugar dos Jogos em causa. 
... atrelou ${ }^{6}$ ao carro] os cavalos;

e eles voavam...

... de homens (?)

... a outras (?)

... outro (?)...

... mais fecundo...

Estrofe 2

(faltam cinco versos)

(faltam três versos)

Antistrofe 2

tal...

belo (?)...

... quando

... à falta de esposos (?)

$\cdots$

(faltam seis versos)

Epodo 2

${ }^{6} \mathrm{O}$ sujeito deve ser Zeus, ou Poséidon. A lenda etiológica segue assim: habitavam em Ceos os Telquines, governados por Dámon. Os deuses enviam um sonho a uma das suas filhas anunciando a destruição da sua civilização, aconselhando a que abandonem a cidade e fujam para outro local, de forma a escaparem à calamidade. Já afastadas da terra natal, mas divagando ainda sem terem alcançado um porto de abrigo, chegam junto delas dois deuses (Zeus e Apolo, ou Poséidon em vez do último), disfarçados de forasteiros, e são acolhidos por uma das jovens que, sem grandes capacidades, se desculpa de os não poder receber mais condignamente. Um dos deuses profetiza a chegada de um herói que dará, a uma delas, um filho. Três dias depois, conforme anunciado, chega Minos, que se deita com Dexítea e, antes de regressar a Creta, lhe deixa metade do seu exército como garantia de proteção. Dez meses depois nasce Euxântion, de onde descende a raça dos Euxantidas, habitantes primordiais da ilha de Ceos. 
Baquílides

... raparigas [tecedeiras (?)

... Lis] ágora ${ }^{7}$

... de um sono doce para o espírito

... da nossa

... antiga cidade

jamais] fujamos

e casas nas] margens do mar

(faltam seis versos e todo o epodo 3)

(falta um verso)

... Lis]ágora (?)

... e Macelo...

... que ama a roca

... e pelo trilho de bela corrente ${ }^{8}$

... então lhes falou

... com voz elogiosa:

«... estou privada

Antistrofe 4

... por uma desgraça de dois gumes

... pela pobreza (?)...

... fugi (?) completamente

7 Na versão de Baquílides, cada uma das três jovens tem uma função específica: Liságora (?) é a recetora, em sonhos, da profecia divina; Macelo, a que fica para trás, para honrar o marido; e Dexítea a progenitora de Euxântion e de toda uma nova raça digna de elogios que desemboca na família do atleta.

${ }^{8}$ Referência provável ao rio Elixo de Ceos. 
(faltam dois versos)

(faltam o epodo 4, a estrofe e antístrofe 5)

(faltam dois versos do epodo 5)

Epodo 5

...

... e ao cabo do terceiro

dia o belicoso Minos

chegou em cinquenta navios

de popas radiantes com uma hoste de Cretenses.

E por vontade de Zeus de boa fama com a donzela de cintura funda, Dexítea, então partilhou o leito.

Deixou-lhe metade dos homens, varôes versados na guerra, por eles a terra escarpada repartiu e, afastando-se, rumou à amável cidade de Cnossos

esse rei filho de Europa? Antistrofe 6 Ao décimo mês ${ }^{10}$, a Euxântion

deu à luz a ninfa] de belas tranças,

o que dessa [ilha] carregada de glória seria] o soberano

(faltam dois versos)

${ }^{9}$ Minos.

${ }^{10} \mathrm{O}$ tempo de gestação era contado pelo ciclo lunar, daí esta precisão. 
(faltam seis versos)

Epodo 6

138 ... fugi] ram as filhas (de Dámon?)

para fundar?] uma cidade ${ }^{11}$ banhada

Estrofe 7

140 pelo sol. E da sua linhagem

nasceu o herói de forte punho,

Argeu, [o que tem] do leão

o ânimo, sempre e quando

a necessidade de lutar se impóe,

145 ligeiro (?) de pés, o que de seus pais

não defrauda (?) os belos feitos,

quantos ao descendente de Pântides ${ }^{12}$,

Antistrofe 7

o ilustre [deus do] arco, Apolo, concedeu, tanto pela sua dedicação à medicina

150 como pela honra amigável pelos hóspedes.

Bem favorecido pelas Graças

e por muitos mortais admirado

terminou os seus dias, cinco filhos

dignos de elogio deixando.

155 A um deles, o Crónida

Epodo 7

de elevado trono ${ }^{13}$ vencedor Ístmico

tornou, em recompensa das suas boas açóes,

e partícipe de outras fulgurantes grinaldas.

Digo e direi que a suprema

160 glória a detém a excelência. Já a riqueza,

${ }_{11}$ Deve tratar-se de Corésia, cujo nome proviria do grego korai («raparigas»).

${ }^{12}$ Pai do atleta Argeu.

${ }^{13}$ Zeus ou Poséidon. 
até de homens comuns é companheira,

e apraz-lhe insuflar o espírito Estrofe 8 de um; mas quem trata bem os deuses, na esperança de uma glória maior conforta o seu coração. E se de saúde

um mortal tem a sua quota-parte, e viver do que tem lhe é dado, com os primeiros rivaliza. Em tudo o prazer a vida dos homens

acompanha, longe que estejam doenças

e a irremediável pobreza.

Da mesma forma o que é rico almeja grandes bens, e quem menos tem coisas menos valiosas. Mas tudo conseguir com facilidade não é tarefa doce para os mortais, antes o que lhes foge sempre estão eles em busca de alcançar.

A quem quer que muito ligeiras ambições revolvam o coração, apenas enquanto vive recebe honra.

A excelência, essa, é laboriosa, mas, se conduzida a cabo com retidão, tal homem, mesmo que morto, deixa um invejável monumento de boa fama. 
Baquílides

\section{AO MESMO ${ }^{14}$}

Avia-te, Fama que dás glória imensa,

Estrofe

para Ceos, a sagrada, e leva contigo

esta notícia de gracioso renome,

que na luta de audazes punhos ${ }^{15}$

Argeu obteve agora vitória;

os êxitos recordou, os que no afamado

Antistrofe

estreito do Istmo, quando deixámos

a divina ilha de Euxanto ${ }^{16}$,

patenteámos com as nossas

10

setenta grinaldas.

E a musa do lugar ${ }^{17}$ invoca

Epodo

o doce ressoar das flautas,

para honrar com cantos epinícios

o filho querido de Pântides.

${ }^{14}$ A ode 2 celebra o mesmo triunfo que a ode 1 , podendo ter sido apresentada imediatamente depois do triunfo.

${ }^{15} \mathrm{Vd}$. supra, nota 1.

${ }^{16}$ Ceos.

${ }^{17}$ O local da vitória (o Istmo de Corinto) ou a terra do atleta (Ceos). 


\section{ODE 3}

Trata-se do mais conhecido e famoso epinício conservado de Baquílides, comemorativo da vitória conseguida pela equipa de éguas (vd. infra, nota 20) de Hierão, tirano de Siracusa entre 478 a.C. e a sua morte, na corrida de carros de quatro cavalos (quadriga) em Olímpia. Considerado já pelos comentadores antigos o ponto mais alto da carreira profissional de Baquílides, o epinício terceiro, cronologicamente o último dos três dedicados pelo poeta a Hierão de Siracusa (odes 3, 4 e 5) apresenta a particularidade de o episódio mítico elegido não recorrer a um herói canónico ou mais universal, antes à história (ou lenda histórica), polvilhada de fantástico, da morte do último governante da Lídia, Creso, que a historiografia e a arqueologia confirmam ter existido e reinado menos de um século antes do triunfo atlético ao qual a composição da ode se reporta (vd. infra, notas 26 e 31 ).

A tomada de Sardes e o desfecho do reinado de Creso (vd. infra, nota 26) foram assuntos bem cedo transformados em lenda. Entre outros argumentos, prova-o a ilustração do mesmíssimo episódio na famosa e táo comentada ânfora de figuras vermelhas atribuída por Beazley ao pintor Míson (Louvre G197), proveniente da Etrúria e datada pelo mesmo autor da primeira metade do século $\mathrm{V}$ a.C., mas que não deve ser posterior a 490 480 a.C. - portanto, duas ou três décadas anterior ao epinício de Baquílides. Parece claro que a cena pictórica se centra na voluntariedade da decisão de morrer de Creso 
e, como tal, a versão do poeta de Ceos perde pretensôes de originalidade, pois que a tradição que segue existiria já pelo menos desde o tempo de Míson.

Composta em obediência à estrutura tripartida tradicional do epinício, com mito central, a ode 3 é particularmente expressiva pela forma como leva a cabo a transição da narrativa real (Hierão, Siracusa, o triunfo atlético e a cidade) para a narrativa mítica, por via da riquíssima sentença dos versos 21-22, que insiste na necessidade de prestar honras a Apolo, atividade que une de forma imediata Hierão (as trípodes e todo o ouro dedicado a Delfos) e Creso, igualmente famoso pela sua devoçâo ao deus que, no momento derradeiro, traslada o corpo do monarca lídio para as bem-aventuranças dos Hiperbóreos (vv. 57-62), paraíso mítico de felicidade e gozo eternos.

Um dos assuntos que mais intrigou os estudiosos de poesia coral grega foi a encomenda desta ode a Baquílides e não a Píndaro, desde logo porquanto o último havia composto diversas odes para o tirano (Olímpica 1, Pítica 1,2 e 3) e mesmo manifestado o seu desejo de vir a celebrar o seu triunfo na quadriga (Olimpica 1, vv. 108 sqq. - de 476 a.C.). Das mais diversas naturezas foram as explicaçóes avançadas para este feito, sempre na tentativa (preconceituosa) de demonstrar a indisponibilidade do poeta tebano; mas o certo é que, em rigor, nenhum dado em concreto nos permite concluir algo além da simples possibilidade de Hierão, sem mais, ter preferido Baquílides a Píndaro.

Acreditava o primeiro editor de Baquílides (F. G. Kenyon 1897: XXVIII) que o epinício havia sido executado em Delfos, por ocasiáo da dedicatória ao santuário de Apolo de duas trípodes por parte do tirano, comemorativas da 
mesma vitória em Olímpia. Para tal, baseava-se Kenyon nas referências do próprio Baquílides às trípodes patentes à entrada do santuário de Delfos (vv. 17-22) e às inúmeras oferendas em ouro de Hierão (vv. 63-66) - que colhem de resto um paralelo imediato nas oferendas que, no plano da narrativa mítica, também Creso enviou para Píton (vv. 61-62) -, além do evidente destaque concedido à figura de Apolo como salvador do monarca lídio (vv. 28, 58-60). De qualquer modo, cedo foi abandonada a hipótese de Kenyon relativa ao local e às motivaçóes de apresentação do epinício, preferindo os críticos considerar que ele tenha sido apresentado em Siracusa, aquando do regresso a casa da equipa vencedora. Para isso aponta a invocação do poema na primeira Estrofe (vv. 1-4), onde se convoca o auxílio de Deméter e Core, duas divindades tutelares da Sicília, em especial de Siracusa, naquilo que pode constituir uma relação direta, se acreditarmos no testemunho de Heródoto (7.153), que nos informa que o próprio Hierão foi sacerdote dessas deusas.

Com isto se percebe como Baquílides, compondo para Siracusa e para o seu chefe político, optou por abrir o poema no mais perfeito espírito religioso da ilha. Dito de outro modo, não é apenas o tirano e o amante e patrono de desporto que é alvo de encómio, mas também o chefe máximo da religiosidade local, no contexto de uma ode integralmente política, composta em função da pólis e para a pólis. 


\section{A Hieráo de Siracusa, pela Quadriga em [OLÍ] MPIA}
A soberana da Sicília de excelentes frutos, Estrofe 1 Deméter, e Core ${ }^{18}$ de grinalda de violetas canta, ó $\mathrm{Clio}^{19}$ de doces benesses, e as velozes e vencedoras éguas olímpicas ${ }^{20}$ de Hierão.

Pois [lançaram-se] com a proeminente Vitória Antistrofe 1 e a Glória nas margens do [Alfeu] ${ }^{21}$ de amplos remoinhos, [onde o filho] de Deinómenes ${ }^{22}$ tornaram próspero na obtenção de grinaldas.

E gritou a multidão...

«Três vezes afortunado [o homem, que, de Zeus tendo conseguido o dom de governar sobre muitos Helenos, sabe a sua riqueza, altiva como torres, não ocultar sob o negro véu da escuridão.»

${ }^{18}$ Core e Deméter são divindades titulares da Sicília, região devota dos Mistérios de Elêusis que, no âmbito do mito, tinham em homenagem a estas deusas sido instituídos. Sabemos por Heródoto (7.153) que Hierão, além de chefe político, teria sido também o sacerdote oficial do templo das deusas.

${ }^{19}$ Uma das Musas, cedo associada ao relato histórico.

${ }^{20} \mathrm{O}$ texto é claro quanto ao género dos animais, precisão na qual o poeta insiste no fr. 20C, composto também para Hierão (v. 4). A epigrafia mostra que Baquílides pode estar a refletir uma prática comum no século $\mathrm{v}$ a.C., a do uso de éguas para competiçôes desportivas.

${ }^{21}$ Rio de Olímpia.

${ }^{22}$ Pai de Hierão. 
Vibram os santuários em festas com sacrifício

[de bois,

Estrofe 2

vibram de hospitalidade as ruas;

brilha rutilante o ouro

das altas e bem cinzeladas trípodes ${ }^{23}$

diante do templo, onde o supremo altar

Antistrofe 2

de $\mathrm{Febo}^{24}$, junto às correntes da Castália ${ }^{25}$,

as gentes de Delfos administram. $\mathrm{O}$ deus, o deus

seja honrado - eis a melhor das sortes!

Em tempos, também ao soberano

Epodo 2

da Lídia domadora de cavalos,

quando em cumprimento

da predestinada sentença de Zeus

foi tomada] Sardes [pelo exército] dos Persas,

também a Creso ${ }^{26}$ o deus de dourada [lira,

Apolo, protegeu. Chegado o dia inesperado,

Estrofe 3

23 A arqueologia demonstrou que os filhos de Deinómenes terão mandado erguer quatro trípodes em Delfos. Vd. R. C. Jebb 1905: $452-$ 457 e B. Gentili 1953: 199-208, 1958: 76-84.

${ }^{24}$ Apolo.

${ }^{25}$ Fonte de Delfos, cujas águas tinham funções rituais.

${ }^{26}$ Creso subiu ao trono da Lídia no seguimento da morte do pai, Aliates II (c. 609/619-560 a.C.), vindo a ser o último rei do Império antes da conquista pelos Persas. Permanecendo a Lídia como o último bastião iónico contra o crescente poder persa na Anatólia, Creso inicia uma grande campanha contra o inimigo, e é neste contexto que se situa a lendária consulta do oráculo de Delfos, que lhe terá respondido, ambiguamente, que caso avançasse haveria de destruir um grande Império. Interceptado perto do rio Halys, na Anatólia central, o exército de Creso e dos seus aliados é derrotado, por volta de 547 a.C. 
da escravidão não se dispunha ele aceitar as muitas lágrimas; então, uma pira diante do pátio muralhado de bronze

mandou erguer e para ela subiu com [a esposa] [fiel Antistrofe 3

e as filhas de belas tranças,

35 que choravam inconsoláveis. As mãos levantando às alturas do céu,

gritou: «Ó divindade arrogante ${ }^{27}$, Epodo 3 que é feito da graça dos deuses? Onde está agora o soberano filho de Leto ${ }^{28}$ ?

40 Em ruínas se vão] os palácios de Aliates ${ }^{29}$, ... de inumeráveis

$$
\cdots
$$

... cidade, Estrofe 4 ruborescem de sangue [os dourados

45 remoinhos do Páctolo ${ }^{30}$, sem honra as mulheres de bem construídos aposentos são arrastadas.

Agradável é o antes odioso! O mais doce é [morrer!» Antistrofe 4 Assim falou, e ao [[servo]] de requintado passo ordenou que incendiasse a morada de madeira. Gritavam as donzelas, as mãos queridas à mãe

${ }^{27}$ Zeus, ou uma referência mais geral ao destino.

${ }^{28}$ Apolo.

${ }^{29}$ Pai de Creso.

${ }^{30}$ Rio da Lídia, em cujas águas douradas o poeta simboliza a riqueza de Creso. 
lançavam - pois a que se tem ante os olhos

Epodo 4

é para os mortais a mais odiosa das mortes.

Mas quando do terrível fogo

a refulgente força se levantou,

Zeus lhe sobrepôs uma nuvem [negra

e extinguiu a loura [chama.

Inacreditável não é nenhuma decisão dos

[deuses.

Estrofe 5

Em seguida Apolo, o que nasceu em Delos,

levou para a terra dos Hiperbóreos ${ }^{31}$ o ancião

e com as filhas de finos tornozelos aí o estabeleceu,

graças à sua piedade, já que as melhores

[oferendas

Antistrofe 5

dos mortais à sagrada Pito $^{32}$ tinha enviado.

De quantos vivem na Hélade, ninguém ousará

- ó muito celebrado Hierão -

afirmar que mais ouro do que tu

Epodo 5

65

enviou a Lóxias ${ }^{33}$, de entre os mortais.

${ }^{31}$ A salvação de Creso varia consoante as versôes. Salvo da pira ora por Zeus, ora por Apolo, é também comum que esse ato seja atribuído ao próprio Ciro - rei dos Persas -, arrependido no momento derradeiro. Baquílides constitui o único caso em que, após a salvação imediata, Creso recebe a honra da imortalização pela trasladação para a terra dos Hiperbóreos, cuja mais completa descrição antiga pertence a Píndaro (Pítica 10.29-46). Em ambos os poetas, a nova morada neste paraíso constitui um prémio pela piedade demonstrada por um mortal para com a divindade.

${ }^{32}$ Delfos. A serpente Píton habitava o santuário, e foi a sua derrota por Apolo que permitiu a instituição do culto ao deus e dos Jogos.

${ }^{33}$ Apolo. 
Elogiar se impóe, para quem

não engorde na inveja, um varão

querido aos deuses], dado a cavalos e guerreiro,

do cetro de Zeus [hospitaleiro

detentor e das Musas [de tranças violáceas.

Estrofe 6

... no passado...

... efémero...

... contemplas; breve é o tempo da vida!

Mas a alada esperança [deslaça] o pensamento

Antistrofe 6

dos seres efémeros. Também o soberano [[Apolo]] que atira ao longe] antes disse [ao filho] de Feres ${ }^{34}$ :

«Mortal que és, impóe-se que nutras

dois pensamentos: que amanhã verás,

Epodo 6

80

e depois não mais, a luz do Sol,

ou que durante cinquenta anos

uma vida de grande riqueza cumprirás.

Praticando atos justos alegra o coração;

de todos os proveitos é esse o mais elevado.»

A quem é sensato entoo coisas compreensíveis.

Estrofe 7

O profundo éter é imaculado; a água do mar não apodrece; o ouro é felicidade;

ao homem não é dado, atingida a grisalha

${ }^{34} \mathrm{Na}$ secção tradicionalmente reservada às sentenças finais, Baquílides introduz um segundo mito, aquele em que Apolo foi condenado a servir como boieiro às ordens de Admeto, filho de Feres, rei de Feras, na Tessália. Deste episódio resultou um conjunto de máximas que colheram diversos tratamentos poéticos e que cumprem, neste ponto, o objetivo de reforçar a autoridade poética das sentenças prescritas a Hierão. 
velhice, a florescente juventude Antistrofe 7 recuperar. Pois não fenece a luz da excelência, entre os mortais, juntamente com o corpo, antes a Musa a alimenta. Hierão, da tua prosperidade

exibiste aos mortais as mais belas flores! Mas ao que pratica boas açóes não lhe traz honra alguma o silêncio. E, com a verdade das tuas boas açóes, há de também cantar-se a graça ${ }^{35}$ do rouxinol de Ceos, o da língua de mel.

35 "Graça» deve ter, neste ponto, o sentido de "presente poético", referindo-se à própria canção e, com isso, adivinhando a fama poética pela presente celebração de Hierão. 


\section{Ode 4}

Composta por não mais do que um par de estrofes, algo pouco frequente nos epinícios que conservamos, tanto os de Baquílides como os de Píndaro, a ode 4 constitui o exemplo mais antigo de um poema sem mito desse género. A epígrafe legível no papiro apenas informa com segurança que a ode celebra um triunfo de Hierão nos Jogos Píticos, mas o verso 6 vem confirmar tratar-se da modalidade da quadriga. Mais, uma hipótese do escoliasta à Pítica 2 de Píndaro informa que essa vitória, também celebrada por Píndaro na Pítica 1, teria ocorrido na $29^{a}$ edição desse festival, ou seja, em 470 a.C. A ode 4 seria portanto, em termos cronológicos, o segundo epinício composto por Baquílides para Hierão, imediatamente depois da ode 5.

Precisamente o facto de a extensa Pitica 1 de Píndaro celebrar a mesma vitória levou os críticos a considerar que Hierão tivesse encomendado cantos epinícios a ambos os poetas, sendo que teria sido o tebano o eleito para compor a ode oficial, com fins políticos mais marcados. H. Maehler (1982: 6; 2004: 101), por seu turno, considera sintomática dos propósitos políticos do poema pindárico a escolha do adjetivo Aitnios ("do Etna”) para Hierão, ao passo que Baquílides se lhe refere ainda com o tradicional Syrakosios ("de Siracusa"). A ser assim, a ode do tebano teria sido encomendada para ser executada no Etna - um autêntico jogo de propaganda -, enquanto a de Baquílides poderia bem ter sido enviada pelo próprio poeta, antes do concurso e para aí mesmo ser apresentada, prevendo já a vitória de Hierão. 
Sobre estes assuntos, como se compreende, não podemos ter certezas, e o risco de sermos levados pelo preconceito deve ser evitado. 


\section{Ao mesmo, Pela quadriga nos Jogos Píticos}

Ainda ama a cidade de Siracusa

Estrofe 1

Apolo, o de dourada cabeleira,

e honra Hierão, seu justo governante;

pois por terceira vez ${ }^{36}$, no umbigo ${ }^{37}$ da Terra escarpada,

como vencedor Pítico é celebrado,

graças ao valor dos cavalos de pés velozes.

Cantou já o galo de doce voz

de Urânia ${ }^{38}$, senhora da lira,

no passado]; agora, de espírito propício,

novos hinos lhe arremessou ${ }^{39}$.

E uma quarta vez, se em equilíbrio

Estrofe 2

algum deus sustivesse a balança da Justiça ${ }^{40}$,

louvaríamos o filho de Deinómenes.

É portanto lícito que o único dos mortais

${ }^{36}$ Os jóqueis de Hierão tinham já vencido nos Jogos Píticos de 482 e 478 a.C.

${ }^{37}$ Este «umbigo», uma rocha cinzelada e colocada no centro do Templo de Apolo em Delfos, e que ainda hoje se pode contemplar no museu desse sítio arqueológico, marcava na Antiguidade o centro do mundo.

${ }^{38}$ Auto-referência do poeta. Urânia era a musa dos fenómenos celestes e da astronomia, no que deve ser uma associação mais tardia.

39 Pode estar em causa o costume de arremessar grinaldas de flores ao vencedor, mas também a imagem do carro da poesia é possível.

${ }^{40}$ Não se conserva qualquer indício de uma prova anterior cuja vitória tenha injustamente sido negada a uma equipa de Hieráo, pelo que é plausível que esteja em causa um quase triunfo nos mesmos Jogos, possivelmente noutra modalidade. 
que nos vales de Cirra $^{41}$ que o mar cerca

tal conseguiu ${ }^{42}$, o cubramos de grinaldas

e duas vitórias olímpicas

lhe celebremos. Que há de melhor do que ser

querido aos deuses, e de todo o género

de bênçãos receber a sua quota-parte?

${ }^{41}$ Porto de Crisa, nos arredores de Delfos, por vezes referido como sinédoque dessa regiáo. Destruído em 585 a.C., a sua fama poética manteve-se contudo ativa.

${ }^{42}$ Não é claro se o poeta fala das três vitórias equestres ou, em termos globais, de toda a prosperidade de Hierão. 


\section{ODE 5}

O epinício 5, o segundo em extensão e um dos mais bem conservados do corpus de Baquílides, celebra a vitória da equipa patrocinada por Hieráo na corrida de cavalos em Olímpia, em 476 a.C., triunfo que também Píndaro canta na Olímpica 1. Cedo se questionaram os comentadores se a ode constituiria um encargo formal de Hierão - que para a ocasiáo contratara os serviços de dois poetas -, ou se Baquílides, buscando apresentar a sua arte ao tirano de Siracusa, enviara autonomamente a composição desde Ceos, questão que não conseguiu ainda resposta segura.

$\mathrm{O}$ tom epistolar da ode, entre outros argumentos, levou a que alguns autores duvidassem da sua classificaçấo como epinício, questão atualmente superada. Com efeito, pesem embora alguns elementos tradicionais do género serem alvo de um tratamento no mínimo especial, a composição obedece à estrutura tripartida do epinício, com uma primeira secção dedicada aos contextos de composição e apresentação (vv. 1-55), um extensíssimo relato mítico com função paradigmática (vv. 56-175) e uma secção final (vv. 176-200), paralela à primeira, na qual se regressa ao tempo presente da vitória e da sua celebração.

Depois de uma introdução a cargo do poeta (vv. 5678), a Antístrofe 2 coloca-nos no tempo e no espaço do mito, apresentando-nos Héracles no Hades, em busca de Cérbero e rodeado pelas almas dos mortos, entre as quais vislumbra Meleagro, herói que não reconhece a início (vv. 56-70). Assustado pelo perfil guerreiro do varão que tem 
à sua frente, prepara-se o filho de Alcmena para sobre ele disparar uma seta, mas logo é advertido de que tal seria em vão (vv. 71-83). Héracles pergunta pelo responsável pela morte desse herói (vv. 84-90), e é em resposta que Meleagro conta parte da sua história (vv. 94-154), a relativa às lutas contra o javali de Cálidon (vv. 97-120), a posterior guerra civil pela pele dourada do animal, da qual resulta a morte acidental, às suas mãos, dos dois tios (vv. 121-135) e, por fim, a ação vingadora de Altaia, sua mãe, que redundaria na sua morte (vv. 136-154). Assistimos em seguida ao pormenor, no mínimo curioso e confessadamente inédito, de Héracles a chorar (vv. 155-158), ao que se segue a demanda, por parte do último, de uma jovem da família do seu interveniente para casar - por respeito ao herói que tem diante de si (vv. 165-169) -, oferta à qual Meleagro, pondo um fim imediato à narrativa mítica, responde com o nome e uma primeira descrição impressionista de Dejanira (vv. 172-175).

Tem-se reparado nos tons sombrios e pessimistas da narrativa mítica de Baquílides, algo sobremaneira evidente nesta ode. Mais do que apresentar Héracles e Melegaro como contrapontos de Hierão - pois que o assunto narrativo é a morte (concretizada ou pressagiada) dos dois primeiros -, Baquílides parece insistir, com este episódio e a cada passo, na humanidade inerente a cada indivíduo, seja ele o próprio Hierão, sejam eles dois dos mais ilustres heróis épicos. Afinal, entre a vida e a morte, entre o heroico e o humano, o longo mito da ode 5, mais do que negar o sentido da vida, parece reafirmá-lo. Porque, com o pessimismo que há que reconhecer-lhe, ao mesmo tempo que ilustra a máxima segundo a qual "nenhum dos mortais/ em tudo nasceu bem-afortunado" (vv. 54-55), funciona como incentivo à 
Baquílides

superação dessa fatalidade, isso sim uma possibilidade aberta apenas a poucos homens ou heróis. 


\section{5. [AO MESMO, PELA CORRIDA DE CAVALOS EM OLÍMPIA]}

Abençoado estratega dos Siracusanos, Estrofe 1 esses que rápido conduzem os carros, apreciarás este adorno ${ }^{43}$, doce dádiva das Musas de grinaldas de violetas, como nenhum outro que habita a terra,

com retidáo! A tua mente muito justa descansa, tranquilo de preocupaçóes, e para aqui volve o teu pensamento; pois, com as Graças de cintura funda tendo urdido um hino, este teu hóspede da sua divina ilha para a vossa ${ }^{44}$ ilustre cidade o envia agora, ele que de Urânia de diadema de ouro é afamado servidor. E é seu desejo, a voz derramando do fundo do peito,

honrar Hierão. O profundo Antistrofe 1 éter cortando com as suas asas pardas e velozes, lá bem no alto, a águia ${ }^{45}$, mensageira do senhor de vasto poder,

${ }^{43}$ A cançáo de vitória.

${ }^{44}$ Este plural (repetido no v. 32) refere-se a Hierão e aos irmãos. Cf. vv. 35-36.

${ }^{45} \mathrm{O}$ longo símile da águia, que ocupa toda a antístrofe, terá funcionado como imagem tríplice do poeta, do poder de Hierão e da velocidade invencível 
Zeus de alto bramido, confia corajosa no seu poder supremo, e acobardam-se as aves de agudas vozes com medo.

Não a detêm os cumes da terra imensa ou sequer as ondas escarpadas, do mar que se não cansa; antes, em espaço ilimitado, revolve a delicada plumagem aos sopros do Zéfiro ${ }^{46}$, inconfundível visão para os homens.

Assim eu disponho agora de milhares de

$$
\text { [caminhos, }
$$

em todas as direçôes, para a vossa excelência celebrar, graças à Vitória de escuras tranças, e a Ares de peito de bronze, a vós, os nobres filhos de Deinómenes. De vos fazer bem não se canse o deus! A Ferenico ${ }^{47}$, o da loura crina, junto ao Alfeu $^{48}$ de amplos remoinhos, esse corcel de galope de tempestade, viu-o vencer a Aurora de braços de ouro,

do cavalo Ferenico, em seguida descrito. A imagem da águia de Zeus como mensageira do triunfo, frequente na poesia pindárica (e.g. Nemeia 5.21, Olimpica 2.86-89, Nemeia 3.80-82), levou à designação tradicional de Píndaro como «a águia tebana».

${ }^{46} \mathrm{O}$ vento do oeste.

${ }^{47} \mathrm{O}$ mais famoso cavalo dos estábulos de Hierão, cujo nome é falante («o que traz a vitória»), pelo que deve ser uma criação poética.

${ }^{48}$ Rio de Olímpia. 
e também em Pito ${ }^{49}$, a sagrada.

Apoiando a mão sobre a terra declaro:

jamais, por cavalos que o precedessem

na competição, o salpicou a poeira

enquanto se lançava para a meta.

Semelhante ao ímpeto de Bóreas ${ }^{50}$,

em obediência ao seu timoneiro

ele se lança, e uma recém-aplaudida

vitória ao hospitaleiro Hierão oferece.

Próspero é todo aquele a quem o deus

uma porção de sucesso concedeu,

e lhe permitiu com sorte invejável

uma vida de opulência ir levando.

É que nenhum dos mortais

em tudo nasceu bem-afortunado.

Certa vez] o destruidor de portas,

Antistrofe 2

- assim contam -, [o invencível filho

de Zeus do raio lampejante,

desceu às moradas de Perséfone de finos tornozelos

para o cão de afiados dentes trazer

à luz do sol desde o Hades,

esse filho da inacessível Equidna. ${ }^{51}$

Aí, de mortais desgraçados

avistou as almas junto às correntes do Cocito $^{52}$,

semelhantes às folhas que o vento arrasta

${ }^{49}$ Referência aos Jogos Píticos, em Delfos.

${ }^{50}$ Vento do norte.

51 No cumprimento do último dos seus doze trabalhos, Héracles desceu ao Hades para trazer à superfície Cérbero, o cáo dos Infernos, filho de Equidina e Tífon.

${ }^{52} \mathrm{O}$ rio do lamento, apenas um dos rios dos Infernos. 
pelos promontórios resplandecentes

do $\mathrm{Ida}^{53}$ nos quais pascem ovelhas.

E entre elas se destacava a sombra

do intrépido lanceiro

descendente de Portáon ${ }^{54}$.

Viu-o filho de Alcmena, admirável herói,

Epodo 2

no resplendor das suas armas,

a corda de agudo eco colocou no arco

e uma seta de brônzea ponta

75 de imediato retirou, aberto

o tampo da aljava. Mas enfrentou-o

a alma de Meleagro, surgindo diante de si,

e, como o conhecia bem, assim lhe falou:

«Filho de Zeus supremo,

fica quieto, de espírito tranquilo,

e não te ponhas a lançar, para nada,

Estrofe 3

uma áspera seta das tuas mãos

contra as almas dos que já morreram!

Nada receies!» Assim falou. Maravilhou-se

85

o soberano filho de Anfitriáo ${ }^{55}$

e respondeu: «Qual dos imortais

ou dos mortais semelhante rebento

criou, e em que terra?

E quem o matou? Talvez Hera ${ }^{56}$ de bela cintura

${ }^{53}$ Montanha na Tróade.

${ }^{54}$ Meleagro, sobre cuja vida e morte vai versar o mito do epinício. À maneira da épica, é primeiramente designado, como Héracles, pela sua ascendência.

${ }^{55}$ Anfitriāo, esposo de Alcmena, era o pai mortal de Héracles.

${ }^{56}$ A deusa, esposa de Zeus, era a principal oponente de Héracles. 
esse indivíduo ${ }^{57}$ se apresse a enviar

pela minha cabeça. Mas disto, por certo,

a loura Palas ${ }^{58}$ toma conta.»

Replicou-lhe então Meleagro,

banhado em lágrimas: "Coisa difícil

é desviar o curso da vontade dos deuses,

para os homens que habitam a terra!

Antistrofe 3

Caso contrário Eneu ${ }^{59}$, domador de cavalos,

teria apaziguado a cólera da deusa veneranda

de grinalda de flores em botão, Ártemis ${ }^{60}$ de alvos braços,

assim the houvesse suplicado o meu pai

com sacrifícios de muitas cabras

e bois de rubro dorso.

Mas a deusa invencível

manteve a cólera. Enviou então a virgem

um javali possante, implacável guerreiro,

para o Cálidon de formosos campos,

onde, no ímpeto da sua força,

as vinhas dilacerava com os dentes,

destroçando rebanhos e qualquer

dos mortais que lhe fizesse frente.

Contra ele, terrível batalha empreendemos,

Epodo 3 nós, os melhores dos Helenos, persistentemente,

${ }^{57}$ Héracles fala no masculino, o que a audiência terá percebido como certa ironia trágica, conhecedora que era da responsabilidade feminina pela morte de Meleagro - Altaia, a própria mãe.

${ }^{58}$ Atena, tradicionalmente a protetora de Héracles, surge a seu lado em inúmeras ocorrências da literatura e sobretudo das artes plásticas antigas.

${ }^{59}$ Pai de Meleagro e rei de Cálidon, na Etólia.

${ }^{60}$ Ártemis estava irritada com Eneu porque ele a tinha esquecido nas oferendas das suas primícias. 
por seis dias consecutivos. E quando a divindade por fim concedeu o triunfo aos Etólios,

115 então sepultámos os que havia matado esse suíno de potentes guinchos ao soltar a sua força, a Anceu ${ }^{61}$ e Agelau, dos meus fiéis irmãos o mais querido, filhos (?) que] nos palácios preclaros de Eneu

$120 \quad$ Altaia $^{62}$ havia gerado.

... aniquilou-os funesto destino; Estrofe 4 pois não [cessara] ainda a destruidora deusa dos bosques, filha de Leto ${ }^{63}$, a sua cólera; pela pele cor de fogo

125 lutámos persistentemente contra os Curetes ${ }^{64}$ firmes no combate. Foi quando eu, entre muitos outros, a Íficlo e ao valente Afares dei morte, velozes irmãos de minha mãe.

130 É que Ares de ânimo cruel não distingue um amigo na batalha; antes partem cegas, de nossas mãos, as flechas contra as vidas dos inimigos e consigo transportam a morte a quem a divindade determina.

${ }^{61}$ Natural de Tégea, era filho de Licurgo e integrou a expedição dos Argonautas.

${ }^{62}$ Altaia, a mãe de Meleagro, era filha de Téstio, rei de Plêuron, também uma cidade da Etólia.

${ }^{63}$ Ártemis.

${ }^{64}$ Os habitantes de Plêuron, cidade que estava em luta contra Cálidon pela posse da pele do javali. 
Destas coisas não cuidando

Antistrofe 4

a destruidora filha de Téstio,

a minha malvada mãe

desejou a minha morte - implacável mulher! -

e queimou o carvão ${ }^{65}$ de rápida perdição

que da bem cinzelada arca

tinha retirado. $\mathrm{E}$ isso foi

o que o destino decretou

como fim da minha vida. Calhou

que Clímeno ${ }^{66}$, filho de Daípilo,

eu despojava das suas armas,

herói valente e de corpo perfeito,

que diante das torres tinha apanhado:

fugiam eles para a bem construída

e antiga cidade

de Plêuron; mingou em mim a doce vida;

Epodo 4 ciente que me definhavam as forças -

ai, ai! - ao sopro derradeiro chorei, miserável, por abandonar o esplendor da juventude.»

Dizem que o impávido ante o grito de combate

filho de Anfitrião nesse momento apenas

humedeceu as pálpebras, lamentando a sorte

desse mortal que tanto sofrera.

$\mathrm{E}$, em resposta, assim lhe falou:

${ }^{65}$ Conta a versão mais divulgada da lenda que, tendo Meleagro apenas sete dias de vida, as Moiras vaticinaram à sua mãe que o menino havia de morrer no dia em que o lenho que então ardia no lar doméstico fosse de todo consumido. Altaia de imediato o apagou e tratou de conservar, escondendo-o numa arca. Segundo outra versão, tratava-se de um galho de oliveira que Altaia dera à luz juntamente com a criança.

${ }^{66}$ Um dos Curetes, desconhecido além do epinício de Baquílides. 
«para os mortais, não nascer é o melhor,

nem do sol jamais contemplar

a luz! No entanto, nada aproveita

quem destas coisas se lamenta, antes há que falar do que importa cumprir.

165 Alguma donzela haverá no palácio de Eneu versado na guerra, uma das suas filhas, por casar ainda, que no aspeto a ti se assemelhe? Dela, com agrado faria brilhante esposa.» ${ }^{67}$

170 Isto foi o que a alma de Meleagro firme no combate lhe respondeu: «Em casa deixei ficar Dejanira de viçoso colo, ignorante ainda da dourada

175 Cípris que encanta os mortais.» ${ }^{68}$

Calíope ${ }^{69}$ de alvos braços, Antistrofe 5 detém o teu bem construído carro

${ }^{67}$ Deve estar em causa o tópico épico do casamento com o familiar de um herói morto, cujo valor é desta forma reconhecido. Ainda assim, alguns estudiosos têm notado que pode estar implícita uma certa atração homoerótica de Héracles por Meleagro, sobretudo na medida em que o poeta frisa que a mulher pretendida, mais do que simplesmente da família do herói, deve ser, nas palavras de Héracles, semelhante a ele no aspeto (v. 168). De resto, na versão pindárica do mesmo episódio, é Meleagro quem sugere Dejanira para noiva de Héracles.

${ }^{68}$ Como Baquílides narra na ode 16 , Dejanira seria a causa direta da morte de Héracles, concretamente pela túnica embebida no veneno de Nesso que envia ao marido e que incendeia o seu corpo, metaforicamente enquanto imagem da paixão e do ciúme.

${ }^{69}$ Uma das Musas, normalmente associada ao canto (embora não seja essa atribuição da sua exclusividade). 
aqui mesmo! Zeus Crónida

celebra, olímpico soberano dos deuses,

o Alfeu de infatigável

corrente, o poder de Pélops

e $\mathrm{Pisa}^{70}$, de onde veio o ilustre Ferenico,

o que, tendo vencido com as patas na corrida,

chegou à bem muralhada Siracusa

e consigo trouxe para Hierão

a folhagem da boa fortuna.

É conveniente, por honra à verdade,

ser elogioso e a inveja [com ambas

as mãos manter afastada,

sempre que um mortal é bem sucedido.

Um homem da Beócia assim falou,

Hesíodo, o servidor das Musas

glicodoces: "quem os imortais [honrem,

também a fama dos mortais [o acompanha.»

Deixo-me persuadir de bom grado

para elogiosas palavras, não [apartadas] do caminho, enviar a Hierão. Pois assim

florescem os ramos das recompensas,

e oxalá o supremo pai,

Zeus, tranquilos [os conserve] em paz.

${ }^{70}$ Pisa era uma cidade nos arredores de Olímpia, frequentemente referida como sinédoque dessa regiáo e dos Jogos que aí decorriam. 


\section{Odes 6, 7 E 8}

Juntamente com as odes 1 e 2, com estas três odes se completa o grupo das cinco composiçóes epinícias que, tanto quanto nos foi possível conservar, Baquílides dedicou à celebração de vitórias de conterrâneos seus. Sobre as odes 6 e 7, sabemos com segurança que foram compostas pela ocasiáo da vitória de Lácon no estádio para rapazes dos Jogos Olímpicos, feito que o Papiro de Oxirrinco n. ${ }^{\circ} 222$ permite datar de 452 a.C. Porque se trata de poemas breves, não é despropositada a hipótese de terem sido apresentados no recinto dos Jogos, embora em 6.14 se aluda às portas da casa do atleta como local de execuçấo. Independentemente deste aspeto, os estudiosos cedo se viram diante de uma situaçáo estranha - a existência de dois epinícios igualmente breves, de um mesmo poeta, para uma mesma vitória. Talvez por isso, houve quem sugerisse que as odes 7 e 8 fossem parte de um mesmo poema - e o estado fragmentário de ambas é evidente -, teoria atualmente abandonada, na medida em que são muitas e de peso as objeçóes temáticas e mesmo métricas.

A atual ode 8 parece com efeito reportar-se a circunstâncias distintas. Se aceitarmos a reconstrução mais consensual do lacunar verso 9, fica assim identificado o atleta vencedor: Lipárion de Ceos, o filho de Líparon que surge por quatro vezes na lista de vencedores da inscrição de Iúlis (linhas 4, 5, 8, 22) como tendo triunfado três vezes no Istmo e uma em Nemeia. Da modalidade em que triunfou, contudo, nenhuma informação possuímos. Finalmente, e quanto à 
data, nada de seguro pode igualmente ser avançado, mas é coerente considerar a ode sensivelmente contemporânea das anteriores, ou seja, dos finais da década de 60 ou da década de 50 . 


\section{Para lácon de Ceos, pelo estádio [de rapa- ZES] EM OLÍMPIA}

Lácon de Zeus todo-poderoso Estrofe 1 obteve na corrida a mais elevada glória vencendo] nas embocaduras do Alfeu; por quantas vitórias, até agora

a Ceos criadora de vinhas cantaram já em Olímpia, por ter vencido no pugilato e no estádio os jovens, com os seus cabelos

enfeitados de grinaldas! ${ }^{71}$ Estrofe 2

E agora a ti, um hino de Urânia, senhora das cançóes, por obra da Vitória,

- ó filho de Aristómenes de pés rápidos como o vento te honra às portas de casa ${ }^{72}$

15 com cânticos, pois ao vencer no estádio sobre Ceos derramaste um manto de glória.

${ }^{71}$ Alusão ao costume de celebrar o vencedor com cortejos e coros de rapazes ou raparigas que ostentam grinaldas, no santuário do recinto onde se obteve a vitória ou já na terra do atleta. Cf. ode 13, vv. 91-94.

${ }^{72}$ Parece o passo indicar que a cançăo foi executada já em Ceos, diante da casa do atleta. 


\section{Ao MESMO}

Ó brilhante filha de Cronos

Estrofe 1

e da Noite! ${ }^{73}$ A ti o décimo sexto dia do mês cinquenta ${ }^{74}$ em Olímpia [foi dedicado, por vontade [de Zeus, o Crónida] tonitroante,

...

para julgar [a rapidez] de pés ligeiros

dos Helenos e a força notável dos seus membros;

e a quem outorgas a mais respeitável recompensa da vitória, entre os homens glorioso é chamado, e o mais invejável. $\mathrm{O}$ [filho] de Aristómenes agora adornaste com grinaldas, Lácon,

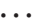

Estrofe 2

... Querolau ${ }^{75} \ldots$

... pela lei sagrada (?)

... morte...

... da pátria...

... do recentemente decidido...

... sem filhos...

(faltam os versos 19-22)

${ }^{73}$ Os estudiosos avançaram com três hipóteses para a figura invocada nestes versos: Hemera, personificação do dia 16 do mês, no qual ocorria a entrega de recompensas em Olímpia; Némesis, filha da noite e deusa das competiçóes desportivas; ou Selene, alegoria da lua.

${ }^{74}$ Os Jogos Olímpicos eram separados por períodos alternantes de 49 e 50 meses, e terminavam ao $16^{\circ}$ dia do mês, durante o qual decorria a entrega dos prémios.

75 Possivelmente um parente morto do atleta. 


\section{8. [A Liparíon de Ceos]}

(faltam 7 versos)

Estrofe 1

8

... concurso...

... o [filho de] Líparon

10

... os filhos [dos] Gregos

... rica em vinhas...

... hinos (?) ...

... em C[eos

15

... sem cavalos (?)

Pito, onde se sacrificam rebanhos,

Estrofe 2

celebrando com hinos, Nemeia e o Istmo.

Em terra apoiando a mão

20 bem alto gritarei: com a verdade

todo o ofício refulge!

Nenhum homem [entre os Helenos

em igual período de tempo,

rapaz ou adulto, maior número

25 de vitórias alguma vez recebeu.

Ó Zeus que lanças o raio! Oxalá nas margens

do Alfeu de argênteos remoinhos também cumpras as preces de glória imensa que dão os deuses, e à sua fronte ofereças a companhia da verde-pálida grinalda 
da oliveira da Etólia ${ }^{76}$

nos ilustres jogos

do frígio Pélops.

${ }^{76}$ Alusão à grinalda de oliveira, prémio simbólico dos vencedores olímpicos. 


\section{ODE 9}

Em data que não nos é dado averiguar, mas que os críticos situaram algures nos anos das Guerras Medo-Persas, ou pouco depois, a nona ode epinícia do papiro de Baquílides vem dedicada a Automedes de Fliunte, vencedor no pentatlo em Nemeia. Trata-se, desde logo, do único epinício conservado para um atleta de Fliunte, cidade na zona nordeste do Peloponeso, a sudeste de Corinto e a escassos dois quilómetros a ocidente do vale de Nemeia, tendo por isso a mais-valia de ser um dos poucos textos que pode abonar a informaçáo plutarquiana do exílio de Baquílides (vd. Introdução).

Apresentando uma estrutura tripartida e simétrica, com mito central (vv. 40-65), cada secção contaria com 39 versos, e apenas a última, devido a lacunas irreparáveis, é de leitura mais difícil. A presente composição tem ainda a particularidade, não exclusiva em Baquílides, de na primeira parte incluir uma narrativa mítica menor, atualizando dois mitos distintos, duas etiologias para o santuário de Nemeia: o confronto entre Héracles e o Leão de Nemeia (vv. 6-9) e o episódio da morte de Arquémoro (ou Ofeltes) durante a estadia em Nemeia do exército dos Sete generais que, liderados por Adrasto, haveriam de atacar Tebas (vv. 10-20; cf. nota 78). A transiçáo para o mito central, o elogio dos descendentes do deus-rio Asopo (cf. notas 83-87), dá-se por via da menção desse rio enquanto realidade topográfica no verso 39, e é da mesma forma que, no verso 66, se retomam as circunstâncias presentes da canção. 


\section{A Automedes de Fliunte, pelo Pentatlo em NEMEIA}

A Reputação, Graças de rocas douradas, Estrofe 1 a que persuade os mortais, oxalá me concedais, já que o divino profeta das Musas de pálpebras violáceas está pronto para Fliunte e a planura de belas flores de Zeus Nemeu

celebrar, onde a fera destruidora de rebanhos a deusa de alvos braços, Hera, criou, dos muito famosos trabalhos de Héracles o primeiro, o leão de penoso rugido. ${ }^{77}$

Foi aí que os heróis de rubros escudos, Antistrofe 1 fina-flor dos Argivos, [por primeira vez montaram jogos por Arquémoro ${ }^{78}$, o que a de fogueados

${ }^{77}$ A luta entre Héracles e o Leão de Nemeia, considerada pelas fontes antigas o primeiro dos trabalhos do herói. Na maioria das versôes, porque a pele do animal era invulnerável a armas de ferro, Héracles teve que derrotá-lo corpo a corpo (ou com auxílio da maça), pelo que o episódio se transformou em etiologia do pancrácio. De qualquer forma, foi após vencer o Leão que, segundo a lenda, Héracles fundou os Jogos Nemeus, depois refundados pelos Argivos que marchavam para Tebas, em honra de Arquémoro (ou Ofeltes), assassinado por uma serpente gigantesca, como em seguida refere o poeta.

${ }_{78}$ Baquílides prefere o nome Arquémoro (à letra «a origem do destino») ao mais comum Ofeltes. Segundo o mito, Adrasto comandava uma expedição contra as sete portas de Tebas para reclamar o poder para Polinices, seu genro. Durante uma paragem em Nemeia, pediu a Hipsípile que lhe indicasse uma fonte onde ele e as tropas pudessem beber. A jovem, responsável pela criança, deixou-a sozinha por momentos, e foi entáo que uma serpente a matou. É que, antes, um oráculo revelara que o infante não 
olhos, monstruosa serpente, matou enquanto dormia ${ }^{79}$, presságio da chacina que estava para chegar. Ó destino todo-poderoso!

Não os persuadiu o filho de Oicles ${ }^{80}$ a de novo marcharem para as ruas de nobres varóes! A esperança se apropria [do juízo] dos homens;

foi ela que, então, a Adrasto, [filho de Tálaon, Epodo 1 enviou a Tebas, com Polinices [destruidor de cavalos. Ilustres sejam entre os mortais os que desses afamados jogos em Nemeia com a grinalda trienal a loura cabeleira venham a cingir! A Automedes ${ }^{81}$, agora, pelo seu triunfo, por certo a divindade lha concedeu.

Pois entre os pentatletas se destacou Estrofe 2 como dos demais astros eclipsa a luz, na noite que divide o mês, a lua de belo fulgor. Assim ele, em imenso círculo de Helenos exibiu o seu porte extraordinário quando lançou o disco circular, quando o ramo de negra folhagem

podia ser colocado no chão antes de saber andar, o que Hipsípile não terá levado em conta.

${ }^{79} \mathrm{Ou}$ "colhia flores», também uma tradução possível para o polémico particípio do texto original, de resto conforme à versão euripidiana do mito na tragédia fragmentária Hipsípile.

${ }^{80}$ Anfiarau, que perante a morte da criança pressagiou a derrota dos sete chefes e aconselhou, sem sucesso, o regresso a casa da armada.

${ }^{81}$ A vitória de Automedes deve ter constituído um acontecimento de extrema importância para Fliunte, cidade do Peloponeso da qual não temos notícia de mais nenhuma vitória nos quatro Jogos maiores. 
do salgueiro arremessou para o alto ${ }^{82}$

céu da sua mão, deixando eufórica a multidão,

ou concluiu o movimento brilhante da luta; Antístrofe 2 e depois que com semelhante força audaz deitou ao chão corpos de robustos membros, veio para junto do [Asopo $]^{83}$ de purpúreos remoinhos.

A reputação deste a toda a terra chegou, [mesmo] aos confins do Nilo ${ }^{84}$. $\mathrm{E}$ as que junto ao trilho de bela corrente do Termodonte habitam, as filhas versadas na lança de Ares $^{85}$ condutor de cavalos,

- ó muito invejável soberano dos dois rios! -, Epodo 2 dos teus descendentes saborearam o valor, [elas e o trono de Tróia ${ }^{86}$ de altas torres. Marcha por vasto caminho, múltipla e em todas as direçóes, a fama

${ }^{82}$ Lançamento do dardo.

$83 \mathrm{O}$ rio de Fliunte, cuja descendência lendária constituiu o mito central do epinício. As fontes variam quanto ao número dos seus filhos e filhas, não sendo claro qual a lista que segue Baquílides. O certo é que todas estas filhas constituem epónimos de cidades e visam, por via da topografia lendária, justificar a expansão da fama da terra do vencedor.

${ }^{84}$ Os «confins do Nilo» podem significar, simplesmente, o limite do mundo conhecido. A um nível mais concreto, poderiam também aludir à morte de Mémnon por Aquiles ou de Busíris por Héracles, sendo que ambos, Aquiles e Héracles, são descendentes de Asopo.

${ }^{85}$ Referência às Amazonas, contra quem lutaram Aquiles e, uma geração antes, Héracles e Télamon.

${ }^{86}$ Com a guerra de Tróia, nos seus dois momentos, se relacionam diversos descendentes de Asopo: Ájax, Aquiles, Neoptólemo, Télamon, Héracles e Peleu. Sobre a descendência masculina afastada de Asopo que lutou em Tróia, em ambas as campanhas, vd. o mito da ode 13 (infra, nota 125). 


\section{da tua linhagem de filhas}

de cintura brilhante, que os deuses, com o auxílio das sortes, estabeleceram como fundadoras de impenetráveis ruas.

Quem há que não conheça de Tebe Estrofe 3 de escuras tranças a bem construída [cidade, ou Egina [de grande fama], que do supremo Zeus [se aproximou] do leito e concebeu um herói ${ }^{87}$ [salvador deste povo], ele que, entre sofrimentos, da terra dos Aqueus,

60

... de belo peplo...

ou [Pirene], donzela da grinalda entrelaçada, Antistrofe 3 e tantas quantas [aos tálamos famosos de deuses se submeteram,

65 filhas] venerandas do ancestral rio ressonante.

... antiga (?) cidade $^{88}$

... vitória...

... os gritos das flautas

${ }^{87}$ Refere-se a Éaco que, segundo a lenda, foi eleito por todos os Gregos para dirigir uma súplica a Zeus pelo fim da carestia que assolava a Hélade. Sobre Egina e a sua descendência, culminando em Ájax e Aquiles, vd. o mito da ode 13.

${ }^{88}$ Depois do mito, de novo Fliunte. Tudo indica que o poeta descrevesse as celebraçốes pela vitória de Automedes. 
e a dourada dadivosa de tranças violáceas louvar, [Cípris, a mãe dos inflexíveis amores

... ilustre para os mortais

...

... hóspede ${ }^{89}($ ?)...

...

... um hino,

que... mesmo depois da morte, Estrofe 4

... tempo que não tem fim...

e aos vindouros sempre patenteie

a tua] vitória em Nemeia. A bela ação

que nobres hinos logrou alcançar

habita nas alturas, junto das divindades.

E com auxílio da verdade dos mortais,

esplendoroso - mesmo após a morte -

prevalece o adorno das Musas ${ }^{90}$ [de cintura funda.

Há, [para a excelência] dos mortais, muitos Antístrofe 4 caminhos]; mas delibera sobre a vontade

dos deuses [o que está oculto pelas trevas] da noite

... e ao mais valente

... a poucos

homens [é dado conhecer] o futuro.

Concedeu[-vos] a graça [de Deméter]

Epodo 4

${ }^{89}$ Auto-referência do poeta.

${ }^{90}$ Deve tratar-se do próprio epinício. 
BAQUílides

e [do Crónida] Diónisos ${ }^{91}$ em cidade honrada pelos deuses habitar], inviolável e florescente.

100 Quando do cetro dourado [de Zeus alguém [consegue] algo de belo, que todos] o celebrem. Ao filho de Timóxeno, com cortejos de rapazes, celebremos agora [a vitória] no pentatlo.

${ }^{91}$ Diónisos e Deméter são mencionados porquanto o vinho e os cereais constituíam as principais riquezas da região. 


\section{ODE 10}

A décima ode epinícia vem dedicada a um Ateniense de nome desconhecido, sendo igualmente duvidosa a prova a que se reporta (o texto conservado apenas aponta para uma modalidade de corrida), pois que o Papiro de Londres não conserva a epígrafe do poema e apenas os Jogos em causa, os Ístmicos, se podem depreender pelo verso 19. Não obstante esta comprometedora falta de informaçáo quanto ao vencedor, de quem apenas nos é dado saber que pertenceria à tribo dos Enidas (v. 18), F. Blass ${ }^{1} 1898$ (ad loc.) sugeriu que se tratava de Aglao, pela reconstruçáo da lacuna inicial do verso 9 do texto, opiniáo no entanto refutada por $\mathrm{H}$. Maehler 1982: 179-181, que julgava ser possível ler o nome do atleta no verso 6 .

Qualquer que seja a hipótese adotada para o nome do vencedor, não dispomos, em rigor, de dados internos ou externos que nos permitam situar o epinício no tempo. Ele revela sim o relacionamento do poeta com as melhores famílias de Atenas, quem sabe por influência inicial de Simónides, mas não constitui sequer prova inequívoca de uma estadia sua na pólis dos Atenienses.

Constituído, no estado em que nos chegou, por duas tríades praticamente completas, e desprovido de mito central, o epinício pode dividir-se em três partes: uma invocação inicial à Fama (vv. 1-8), uma extensa exaltação do vencedor e descrição do seu curriculum de vitórias atléticas (vv. 9-35) e, finalmente, uma igualmente larga secção gnómica (vv. 35-56), com a qual é possível que se encerrasse o poema. 


\section{0. [A Aglao (?) de Atenas, pela corrida de CAVALOS (?) NOS Jogos ÍsTMICOS]}

Fama, tu [que de imortais de mortais] Estrofe 1 visitas as tribos, e a todos (?)...

..., porque para a dourada [Vitória], a bem aventurada, olharam] com seus olhos, o descanso ocioso [permitindo. Para Aglao (?)], também o esposo de sua irmã ${ }^{92}$ espicaçou agora a insular abelha de clara voz ${ }^{93}$,

para que um imortal monumento das Musas Antistrofe 1 sempre lá, para os homens seja motivo de comum alegria, a tua excelência revelando aos mortais,

15 e quão grande glória, graças à Vitória, ao cingir de flores a tua loura cabeça, para Atenas de belas correntes granjeaste, e reputação aos Enidas ${ }^{94}$, nos muito afamados jogos de Poséidon, ao patentear aos Helenos o rápido assalto dos teus pés.

${ }^{92} \mathrm{O}$ poeta refere, sem qualquer explicação, que o epinício foi encomendado pelo cunhado do atleta.

${ }^{93}$ Imagem do poeta.

${ }^{94}$ Uma das tribos da Ática, à qual pertenceria a família do atleta. 
Pois quando, na meta da corrida no estádio, Epodo 1 exalando o seu caloroso alento ele se deteve, e outra vez quando os mantos dos espectadores molhou] de azeite ${ }^{95}$, lançando-se à multidão aglomerada, depois que a corrida

de quatro [voltas] dobrou ${ }^{96}$, vencedor Ístmico por duas vezes o proclamaram os arautos dos avisados árbitros;

e outras duas em [Neme]ia, junto do sagrado [altar Estrofe 2 de Zeus Crónida. Também a ilustre Tebas o recebeu, a de vastos campos, Argos, e Sícion, como era seu dever; e esses que habitam em Palene, em redor de Eubeia de messes abundantes, ou os da sagrada ilha de Egina. ${ }^{97}$ Persegue cada um o próprio caminho, trilhando-o em busca de célebre reputação. Incontáveis são as habilidades dos homens.

O que é sábio, se alcançou a honra das Graças, Antístrofe 2 com a esperança dourada floresce, como se de alguma arte profética fosse conhecedor; outro, contra rapazes

${ }^{95}$ Deve referir-se ao azeite com que os atletas untavam o corpo.

${ }^{96} \mathrm{O}$ atleta, depois da corrida individual, triunfou na corrida de quatro voltas ao estádio (c. 720-800 metros).

97 Nestas cidades o atleta terá participado em competiçóes menores, algo que o poeta considera digno de menção no âmbito do curriculum de Aglao. 
o seu variegado arco distende;

há ainda os que nas lides do campo e com bois

o coração enaltecem. Mas o futuro,

só ele produz resultados que não decidem

para que lado penderá a fortuna. $\mathrm{O}$ melhor

é ser honrado, por muitos muito invejado.

Conheço bem o poder da riqueza,

Epodo 2

ela que mesmo o inútil transforma

em homem útil. Por que tão longe a minha língua levei,

e a dirijo fora do trilho? Estabelecida está para os mortais, após a vitória, a alegria ...

das flautas...

55 mistura-se...

impóe-se que alguém... 


\section{Ode 11}

Não dispomos de dados seguros que nos permitam datar esta composição, dedicada ao jovem Alexidamo de Metaponto pela sua vitória na luta de rapazes nos Jogos Píticos, e só em obediência a um critério de comodidade se pode entender a sugestáo de A. Severyns 1933: 95 em situá-la no período siciliano de Baquílides (c. 476-468 a.C.). A questão não é, com efeito, pacífica: se B. Snell ${ }^{7} 1958$ : XXVIII, XLV considerou o epinício da fase inicial da carreira do poeta, por questóes estruturais e de métrica, já K. Dowden 1989: 736 entendeu que o episódio mítico central do exílio das Prétides no Peloponeso refletia a tradição do seu exílio nessa região, sugerindo assim uma datação na década de 50 do século $V$ a.C. No entanto - e como se compreende -, não é sequer seguro que Baquílides tenha estado em Metaponto aquando da vitória de Alexidamo, se de facto há que integrar o epinício nas primeiras composiçóes do poeta.

Tratando-se de um dos mais extensos epinícios conservados do corpus, acresce a isto o facto de nos ter chegado num quase perfeito estado de conservação, já que apenas os versos 2-3 e 31 apresentam lacunas. A composição, nos 126 versos que a constituem, organiza-se de forma peculiar, sobretudo no que à extensa narrativa mítica diz respeito (infra, nota 101). Não obstante, obedece no essencial à estrutura tripartida básica do epinício, apresentando um proémio inicial (vv. 1-29), um mito central (vv. 40-112) e um epílogo (vv. 113-126), esse sim bastante reduzido e atípico, desde logo porque não retoma o encómio do vencedor ou da 
sua cidade, antes se apresenta como um prolongamento da narrativa mítica. É a composição em anel a técnica narrativa mais evidente do epinício, algo flagrante na narração mítica mas já presente no proémio. Todo o poema se organiza, de resto, num complexo sistema de repetiçóes e ecos linguísticos e conceptuais (constitutivos de várias narrativas em anel) que, no que ao mito diz respeito, assim se podiam sintetizar:
A (40-42)
Preto e as filhas fundam um altar
B (43-54) as raparigas ofendem Hera
C $(43,55-56)$
e são postas em fuga, inspiradas de loucura
D (57-58) por isso abandonaram Tirinte
E (59-63) cidade pela qual os heróis haviam trocado Argos
F (vv. 64-76) pois tinha havido uma disputa, entretanto resolvida
E' (79-81);
$(77-79)$ os heróis abandonaram Argos e passaram a residir em Tirinte; os Ciclopes construíram-lhes as muralhas des- sa nova cidade
D’ (82) e foi daí que as Prétides se puseram em fuga
C' (83-107)
B' (107-109) por causa da sua loucura e fuga, Pretos entra em desespero; elas fogem por treze meses e Preto faz sacrifícios a Ártemis
A' (110-112) e por isso construíram um altar em sua homenagem. 


\section{A Alexidamo de Metaponto, pela luta de RAPAZES NOS Jogos Píticos}

Vitória de doces dádivas! [Só a ti Estrofe 1

concedeu [honra] o pai

de alto trono, [descendente de Urano, e no Olimpo rico em ouro, de pé erguida ao lado de Zeus, decides para imortais e mortais qual o limite da excelência. Compadece-te de nós, deusa [de fundas] tranças, filha de [Estige] justiceira ${ }^{98}$. Por ti também agora ocupam Metaponto

cortejos de rapazes de belos membros

e festas, essa cidade que honra os deuses;

e celebram com hinos o vencedor pítico,

o filho admirável de Faísco.

Com olhar propício o nascido em Delos Antístrofe 1

o recebeu, o filho de Leto ${ }^{99}$ de cintura funda,

o recebeu; e em grande número,

à volta de Alexidamo, as grinaldas

de flores pela planície do Cirra se precipitaram, pela poderosa

luta na qual a todos venceu.

Nem logrou vê-lo o sol,

\footnotetext{
${ }^{98}$ A Vitória é filha de Estige e do titã Palante.

${ }_{99}$ Apolo.
} 
nesse dia, tombar sobre a terra.

Direi mesmo que nos muito divinos

trilhos do sagrado Pélops,

junto ao Alfeu de bela corrente, se da reta justiça

não tivesse alguém desviado o percurso,

com a oliveira verde-pálida ${ }^{100}$ a todos hospitaleira

teria ainda coroado a sua cabeça

Epodo 1

antes de regressar [à pátria Itália] criadora de novilhos.

[[Na verdade, mais do que um]]

jovem, nessa terra de belos campos,

com variegados estratagemas derrubou.

Ou foi um deus o responsável, ou

as sentenças inconstantes dos mortais

lhe roubaram das mãos a suprema recompensa.

Mas agora Ártemis, a deusa dos bosques

de roca de ouro, a apaziguadora,

afamada archeira, brilhante vitória lhe concedeu.

À deusa, certa vez, o filho de Abante ${ }^{101}$

um altar de muitas súplicas erigiu,

ele e as suas filhas de belos peplos;

${ }^{100} \mathrm{Vd}$. ode 8, vv. 29 sqq. e nota ad loc.

${ }^{101}$ Abante gerou, com Aglaia, Preto e Acrísio, dois gémeos que já no ventre da máe se disputavam. Chegados à idade adulta, repartiram entre si a Argólida, ficando Preto senhor de Tirinte e Acrísio de Argos. De Preto e Estenebeia nasceram as Prétides, figuras centrais do mito da ode 11, que segundo umas versóes seriam duas (Lisipe e Ifianassa) e segundo outras três (as duas anteriores e Ifínoe). O poeta conta os antecedentes da história, por uma sucessão de analepses narrativas, mas o segmento central reside na loucura das jovens (por inspiração de Hera, embora outras fontes a atribuam a Diónisos), na sua fuga pelos bosques, na cura por efeito de Ártemis e na instituição do culto a esta deusa, em ação de graças. 
tinha-as posto em fuga dos encantadores

Estrofe 2 palácios de Preto a todo-poderosa Hera, agrilhoando os seus coraçóes

a poderosa sorte que as desnorteava.

É que, com a irreverência da juventude no espírito ${ }^{102}$, tinham ido ao recinto

dessa deusa de cintura purpúrea;

afirmaram então que muito o seu pai

superava, em riqueza, o vasto poder

da loura companheira do venerando Zeus.

Dominada pela cólera, nos seus

íntimos infundiu um pensamento desviante:

e debandaram para a montanha de densa ramagem,

soltando gritos impossíveis de ouvir ${ }^{103}$

ao abandonar a cidadela de Tirinte

e as suas ruas que os deuses ergueram.

Dez anos haviam passado desde que,

deixando Argos, cidade cara aos deuses,

aí habitavam os impávidos ante o grito de guerra,

os heróis de brônzeos escudos,

com o seu muito amado rei ${ }^{104}$.

Foi quando uma inabalável disputa,

de insignificante origem, se levantou

${ }^{102}$ Alguns estudiosos interpretaram a expressão original (partheniai eti psychai) como querendo significar "sendo ainda virgens», pois que o mito parece representar esse estado transitório da juventude para a idade adulta, por via do casamento.

103 As Prétides, na sua fuga, comportam-se como bacantes inspiradas por Diónisos. Daí que, em alguns autores, a sua história se confunda com a da loucura coletiva das mulheres de Argos, por esse deus provocada.

${ }_{104}$ Analepse ao momento em que Preto abandonou Argos para fundar Tirinte, resoluçáo do conflito entre os irmáos. 
entre os irmãos Preto e Acrísio; as gentes arruinavam, com discórdias longe da justiça e com lutas terríveis; suplicaram por isso os filhos de Abante, detentores de uma terra rica em trigo,

que o mais novo deles colonizasse Tirinte, Epodo 2 antes que caíssem em terrível necessidade; foi quando Zeus Crónida consentiu, em honra da linhagem de Dânao e do condutor de cavalos Linceu ${ }^{105}$, pôr termo a essas execráveis afliçóes. A muralha construíram-na os Ciclopes de força extrema, ao chegarem, para a ilustre cidade, formosíssima, para os semelhantes aos deuses habitarem, a famosa e domadora de cavalos Argos tendo deixado para trás os muito ilustres heróis. E foi desse lugar que, em correria, as filhas de escuras tranças de Preto debandaram, indomadas.

por isso decidiu uma espada de dois gumes enterrar no peito. ${ }^{106}$

Mas nesse momento os lanceiros,

90 com palavras consoladoras

${ }^{105}$ Abante era filho de Linceu e Hipermenestra, a última uma das filhas de Dânao.

106 Como Alexidamo sofreu uma derrota e por fim saiu triunfante, também Preto, no mito, conheceu um período de desepero que o levou a tentar a morte, antes que saísse vitoriosa a sua causa. 
e pela força das mãos o detiveram.

Por treze meses completos ${ }^{107}$

vaguearam elas pelo bosque sombrio

e andaram fugidas pela Arcádia

criadora de rebanhos. Quando, por fim,

ao Lusos ${ }^{108}$ de bela corrente o pai chegou,

aí, depois de dar banho ao seu corpo,

a filha de olhos de vaca ${ }^{109}$

de Latona de rubro véu ele invocou,

Antistrofe 3

as mãos erguendo para os raios

do sol de velozes corcéis,

para que as suas filhas libertasse

do terrível frenesim que as atormentava:

«sacrificar-te-ei vinte bois

nunca submetidos ao jugo, de rubro pelo.» ${ }^{110}$

Escutou-o a filha do pai supremo,

a caçadora, compadecida; persuadindo Hera,

dessas donzelas de grinaldas de flores em botão

pôs fim à loucura a que não assistem os deuses.

Elas, um recinto e um altar lhe ergueram,

tingiram-no com o sangue de cordeiros

${ }^{107} \mathrm{O}$ número treze deve ter relação com Ártemis, na sua valência de deusa lunar. De qualquer modo, a interpretaçáo imediata dos espectadores seria a de que a cura ocorreu "no momento certo».

108 Nascente da Arcádia, perto da cidade com o mesmo nome, que os antigos consideravam derivar do verbo grego louestai ('lavar-se'), assim aludindo ao banho ritual de Preto.

109 Ártemis. O epíteto «olhos de vaca» era símbolo de beleza comum a várias figuras femininas.

${ }^{110}$ Está implícito um ritual matrimonial de proteleia, pelo qual um pai oferecia à divindade, em troca da virgindade da filha, um outro animal que simbolicamente a representasse. 
e instituíram coros de mulheres. ${ }^{111}$

Daí, com os Aqueus, varóes versados

na guerra, para uma cidade criadora de cavalos

115 seguiste caminho ${ }^{112}$; em boa hora

assentaste morada em Metaponto

- ó dourada soberana dos povos!

Um prazeroso recinto sagrado, junto ao Casas ${ }^{113}$ de bela água, [os antepassados

120 estabeleceram], quando, com o tempo, por vontade dos deuses bem-aventurados, destruíram a cidade bem construída de Príamo, em companhia dos Atridas de couraça de bronze. Todo aquele que tenha um coração justo

125 achará sempre, na infinitude dos tempos, as incontáveis façanhas dos Aqueus.

${ }^{111}$ Baquílides termina o mito com a etiologia dos Hemerasia, o festival local no qual alguns julgaram que o epinício foi apresentado.

${ }^{112} \mathrm{O}$ poeta relaciona o mito narrado com a terra do vencedor, aludindo à fundação aqueia de Metaponto, no regresso da tomada de Tróia.

${ }^{113}$ Rio a sul de Metaponto que desemboca no Golfo de Tarento. 


\section{ODE 12}

Deste texto apenas se conheciam os primeiros oito versos, até que M. Norsa 1941: 155-163 publicou um novo fragmento do Papiro de Londres que B. Snell, na edição teubneriana seguinte ( $\left.{ }^{6} 1949\right)$, considerou conter os cinco últimos versos de uma Antístrofe e os primeiros cinco do Epodo seguinte, concluindo assim que o poema se prolongaria por três tríades, num total de 72 versos. Quanto à sua datação, não dispomos de quaisquer dados seguros, além da proposta meramente orientadora de A. Severyns 1933: 54 (c. 487-485 a.C.).

Depois da invocação inicial à musa Clio - que, porque também presente na lacunar abertura da ode 13, poderia ser da especial predileção dos Eginetas -, seguem-se as mençóes comuns à pátria, aos jogos e à prova, momento em que se interrompe o primeiro fragmento. Quando de novo nos é dado ler o texto, deparamo-nos com um catálogo de vitórias, seja da pátria em causa, seja da família do vencedor. Dado o estado lacunar do texto, sequer é impossível que, quando completo, contivesse um mito, por breve que fosse. 


\section{Para Tísias de Egina, Pela luta em Nemeia ${ }^{114}$}

Qual timoneiro versado, ó Clio ${ }^{115}$, senhora dos hinos, retos conduz agora os meus pensamentos, se no passado já o fizeste! À próspera ilha de Egina, pelos meus hóspedes, a soberana Vitória me ordena que chegue, para enaltecer uma cidade construída pelos deuses e, em Nemeia, a luta de fortes membros Antistrofe 1 [[cantar] $]$

(faltam os versos 9-32) Epodo 1 Estrofe 2

... hóspede... cidade...

Antistrofe 2

nos jogos das gentes vizinhas;

por trinta ${ }^{116}$ gloriosas

vitórias foram honrados com cortejos, uns [em Pito,

outros na garganta rica em pinheiros

Epodo 2

${ }^{114}$ Não há dados seguros que identifiquem a categoria etária em que a vitória foi conseguida.

${ }^{115}$ Clio é invocada na abertura da ode 3 (v. 3) e, ao que parece, também na ode 13 (v. 9).

116 Parece o número trinta querer significar uma quantidade grande de vitórias, do atleta, da sua família ou mesmo de toda a cidade. 
da sacrossanta ilha de Pélops,

outros ainda no precinto de Zeus Nemeu,

o senhor dos rubros relâmpagos.

Essas [vitórias (?)] também junto às [colinas (?)

do Alfeu (?)]de remoinhos de prata

(faltam os versos 43-69) 


\section{ODE 13}

Constitui a ode 13, com os seus 231 versos, o mais largo epinício conservado do corpus de Baquílides, pesem embora as lacunas mais graves do início do poema que nos fizeram perder, quase na totalidade, os primeiros 43 versos, a primeira tríade inteira e grande parte da segunda Estrofe. Dedicada a Píteas de Egina, filho de Lâmpon (v. 68), deve rondar os anos de 487480 a.C., celebrando a mesma vitória que cantou Píndaro na Nemeia 5. Não obstante, parece indicar que também a ode de Baquílides foi encomendada a proeminência que nela é dada a Lâmpon, pai do atleta, referido por duas vezes (vv. 68, 226) e alvo de especial atenção entre os versos 226-227.

Desde logo pela sua extensão e aceitável estado de conservação, a ode permite vislumbrar o tratamento de todas as partes tradicionais do epinício, sendo possível sintetizar a sua estrutura do seguinte modo: proémio, mormente perdido (vv. 1-45), mito fundacional dos Jogos Nemeus (vv. 46-57), transiçâoo (vv. 58-99 = Epodo 2), elogio do atleta (vv. 67-76) e da sua terra natal (77-90), nova transição (vv. 91-99 = Epodo 3), mito central (vv. 100-167), transição gnómica e sua aplicação ao país do vencedor (vv. 168-189), encómio final do vencedor e do seu treinador (vv. 190-198 = Epodo 6), nova reflexão gnómica (vv. 199-200) e dedicatória do poeta (vv. 221-231).

Baquílides segue a tradição coral egineta ao eleger um episódio mítico protagonizado por descendestes de Éaco (vd. mito da ode 9). Com efeito, dos onze epinícios que Píndaro compôs para celebrar a vitória de atletas dessa ilha, datáveis 
entre 485 e 446 a.C., apenas um deles, a oitava Pítica, não trata, no mito central, de episódios protagonizados por heróis eácidas. No caso em apreço, desenvolve o poeta a aristeia de Ájax e Aquiles (cf. a genealogia infra, nota 125) perante o ataque dos troianos às naus gregas, em plena guerra de Tróia (vv. 100-169). Gritaria alto este mito aos Eginetas, povo em constante luta com a vizinha Atenas, tanto havia sido ele o elegido para figurar na segunda versão dos pedimentos do Templo de Afaia em Egina, os mesmos que a arqueologia demonstrou provável que Baquílides (e a sua audiência) tenham contemplado, estrategicamente colocados num ponto alto da ilha que, contam os turistas atuais, chega a ser visível da Acrópole de Atenas. No pedimento ocidental estão em destaque, ao lado de Atena, Ájax e Aquiles, os mesmos dois Eácidas cujas aristeias Baquílides contempla no epinício para Píteas, ilustrando-se o primeiro assalto da segunda campanha grega contra Tróia. No pedimento oriental, recuase no tempo do mito: a cena parece representar a guerra de Héracles contra Laomedonte (pai de Príamo), no contexto da primeira campanha grega contra Ílion.

Pode de facto ter razão D. Williams 1987: 673 quando, a propósito do mito no epinício em apreço, fala de uma réplica à propaganda de guerra ateniense; da ação cultural de uma ilha que, pela poesia e pelas artes plásticas, buscava apresentar-se ao mundo como a pátria ancestral dos vencedores de Tróia. 
BAQUílides

\section{3. [A Píteas de Egina, pelo pancrácio em NEMEIA]}

(faltam vv. 1-7)Estrofe 1

(faltam vv. 13-33)

(faltam vv. 34-39)

(Estrofe 2)

40

à sua insolência prepotente porá fim ${ }^{117}$, realizando a justiça entre os mortais,

qual mão que ninguém suporta, Antistrofe 2 assim a que ao sanguinário leão o descendente de Perseu ${ }^{118}$ lança,

117 Não chegaram os comentadores a um consenso a propósito da figura que narraria este primeiro mito do epinício: a ninfa Nemeia, irmã de Egina e epónima da terra dos Jogos, ou Atena, a frequente companheira de Héracles na poesia e, sobretudo, na pintura de vasos, essas as hipóteses avançadas.

118 Sobre Héracles e o Leão de Nemeia, vd. ode 9, v. 9 e nota 77. 
com toda a espécie de habilidades;

pois não] quis o refulgente bronze,

o que domina os mortais, o seu corpo

inacessível penetrar, antes

se dobrou] para trás

a espada]. ${ }^{119}$ Afirmo que um dia,

nesse local], pelas grinaldas

do pancrácio, um esforço

suado haverá para os Helenos.»

Por isso agora], junto ao altar de Zeus,

Epodo 2

o melhor soberano,] as flores [da Vitória]

que granjeia glória alimentam para os homens

uma dourada] e evidente reputação

- para poucos mortais apenas -

durante toda a vida, e quando da morte

a escura névoa os cobrir, permanecerá

imortal a glória da sua façanha

com um destino inquebrantável.

Do mesmo te calhou em Nemeia,

filho de Lâmpon ${ }^{120}$,

e com grinaldas de viçosas

flores cingida a tua cabeleira

avanças] para a cidade de altas ruas

Héracles descende de Perseu pelo lado da mãe, Alcmena, e mesmo do pai mortal, Anfitriáo.

119 A luta com o Leão é apresentada como etiologia do pancrácio, no qual obteve vitória Píteas, sobretudo pelo recuperar da tradição da impenetrabilidade da pele da fera por armas de ferro.

${ }^{120} \mathrm{O}$ destaque dado a Lâmpon, pai do atleta, levou a considerar a hipótese de ter sido ele a contratar os serviços de Baquílides. 
de Éaco ${ }^{121}$,] e com alegria para os mortais

[floresce com o delicado som]

dos coros a tua ilha pátria, por a tua força desmedida no pancrácio teres ostentado.

Ó filha de um rio

vertiginoso $^{122}$, Egina de gentil íntimo,

em verdade [o filho de Cronos ${ }^{123}$

Antistrofe 3

te concedeu honra imensa

e entre todos os Helenos [uma nova

vitória, como uma tocha,

fez brilhar. O teu [poder, canta-o

também qualquer orgulhosa [donzela,

[avançando pela terra sagrada]

com seus pés, a toda a hora,

feito corça despreocupada,

que por [colinas] floridas,

ligeira com as suas vizinhas,

esplêndidas companheiras, vai saltitando;

e elas, coroadas de rubras

Epodo 3

flores e folhas de cana,

enfeite da sua terra,

essas donzelas cantam ${ }^{124}$ [o teu filho,

${ }^{121}$ Éaco era filho de Zeus e Egina, e a ele se atribui a fundação da cidade que da ninfa sua mãe, filha de Asopo, recebeu o nome.

122 Asopo.

123 Zeus. Sobre a descendência feminina do deus-rio Asopo, vide o mito principal da ode 9 (supra, nota 83).

${ }^{124}$ Baquílides alude às celebrações locais (femininas) pela vitória de Píteas, primeiro a um nível individual, logo coletivo (coral). Sobretudo no primeiro momento, pela imagem da corça saltitante e fugidia 
ó soberana de terra a todos hospitaleira,

e Endeide de róseos braços,

a que gerou [Peleu, semelhante a um deus,

e Télamon, o guerreiro do escudo, quando a Éaco se uniu no leito;

os seus filhos que levantam batalhas,

o veloz Aquiles

e da bem formosa Euribeia

o altivo descendente vou cantar,

Ájax, herói portador do escudo, ${ }^{125}$

ele que, encostado à proa,

repeliu o varão de intrépido coração

que pretendia [as naus ${ }^{126}$

com o maravilhoso [fogo incendiar,

Heitor [de elmo] de bronze,

no tempo em que [o filho de Peleu

violenta [cólera em seu íntimo

revolveu [e os Dardânidas ${ }^{127}$

Antistrofe 4

libertou [da sua cegueira;

antes, a [muito muralhada

- frequente na poesia grega arcaica e clássica - pode estar em causa uma sugestão de casamento para o jovem Píteas.

${ }^{125} \mathrm{O}$ mito principal é introduzido por via da genealogia mítica dos Eácidas, que assim se pode resumir: Éaco desposou Endeide, de quem gerou Peleu e Télamon; destes descendem, respetivamente, Aquiles (com Tétis) e Ájax (com Euribeia).

${ }^{126}$ Num primeiro momento (vv. 105-109), Baquílides trata do confronto individual entre Ájax e Heitor, que o poeta de Ilíada desenvolve em 15.417 sqq.

127 Os Troianos, assim designados a partir de Dárdano, responsável pela construção das míticas muralhas de Tróia. 
e admirável cidade de Ílion ${ }^{128}$

não abandonaram mas, desnorteados, lançavam-se para a intensa batalha sempre que, tumultuando a planície, Aquiles se enchia de cólera,

120 brandindo a lança assassina.

Mas quando da guerra

se deixou o intrépido filho

da Nereide de grinalda de violetas ${ }^{129}$

- como [o ânimo dos homens] no mar

Epodo 4

125 de escuro florir o Bóreas faz vacilar

por debaixo das ondas,

quando se ergue ao levantar da noite,

mas cessa com a Aurora que ilumina

os mortais], e então aplaina o mar

130 uma suave brisa; os sopros do Noto ${ }^{130}$ incham

a vela e, impacientes já todos,

em terra inesperada aportam -,

assim os Troianos, ao escutarem

Estrofe 5

que o lanceiro Aquiles

135 se mantinha nas suas tendas

por causa de uma loura mulher,

Briseida $^{131}$ de atraentes membros,

aos deuses ergueram as mãos,

128 Tróia.

129 Tétis.

${ }^{130}$ Bóreas é o vento do norte, Noto o do sul.

${ }^{131}$ Uma das princesas de Tróia, dada a Aquiles em sorteio mas raptada por Agamémnon, motivo passional para que o primeiro abandonasse temporariamente o combate. 
pois vislumbravam brilhante luz

por entre as brumas da tempestade.

Deixando para trás, apressados,

as muralhas de Laomedonte ${ }^{132}$,

para a planície se lançaram,

poderosa luta levando consigo;

e provocaram medo aos Dânaos;

Antistrofe 5

inflava-lhes o ânimo Ares

de forte lança e o soberano

dos Lícios, Lóxias Apolo;

assim chegaram à praia do mar.

Junto às naus de bela proa

lutavam, a negra terra

ruborescia com o sangue

dos homens aniquilados

pelo braço de [Heitor

e era grande] para os heróis

o sofrimento], à investida dos semelhantes aos deuses.

Ah, insensatos!], em grandes esperanças

Epodo 5

confiados], e com arrogante voz

gritando,] esses cavaleiros troianos

que, as naus de negra face

[tendo destruído por completo],

contavam regressar a casa e encontrar festins

nas ruas] da sua cidade construída pelos deuses!

Estavam porém destinados

a ruborescer o vertiginoso Escamandro ${ }^{133}$,

132 Pai de Príamo e um dos primeiros reis de Tróia.

${ }^{133}$ Rio de Tróia. 
morrendo às mãos [dos Eácidas

destruidores de torres.

Se os seus...

ou numa pira (?) de altos troncos

(faltam os vv. 170-174)

175 Pois não perde o seu brilho

a Excelência a todos visível, mesmo que a oculte o sombrio [véu] da noite,

antes, firme e florescente de infatigável reputação,

180 difunde-se pela terra [epelo [mar] de muitos desvios. Por certo, a [ilha] portadora de glória de Éaco honra agora, e em companhia da Bela Glória, amiga de grinaldas, dirige o leme da cidade,

185 ela e a prudente Eunomia ${ }^{134}$,

a que tutela as festas

e as cidades dos homens piedosos conserva em paz.

190 A vitória muito ilustre cantai, jovens, Epodo 6 a de Píteas, e o esforço de Menandro ${ }^{135}$ que aos mortais foi tão útil,

${ }^{134}$ Eunomia, aqui personificada, significa à letra «a boa ordem».

135 Treinador ateniense, também referido por Píndaro (e.g. Nemeias 5.48). 
ele que, junto às correntes do Alfeu ${ }^{136}$, tanto honrou a deusa do carro dourado, a venerável e magnânima Atena,

e com diademas a incontáveis varóes coroou já as cabeleiras nos jogos pan-helénicos.

Se alguém há que por desmedida inveja de palavra não esteja tomado, que celebre esse homem habilidoso com justiça. $\mathrm{O}$ vitupério dos mortais impera sobre todas as açóes; a verdade, essa, compraz-se com a vitória, e o tempo todo-poderoso

à ação que de forma bela é realizada sempre a [acrescenta; ao invés, [a língua vã] dos inimigos, envergonhada, vai-se consumindo

na esperança acalenta o coração; nela, também eu confiado, e [nas Musas] de rubros véus, agora ostento, e a hospitalidade dada a esplendores celebro, que, Lâmpon, [dádiva dos teus recursos - e não pequena -, me concedeste [por teu filho;

${ }^{136}$ Alusão a vitórias anteriores de atletas treinados por Menandro. 
BAQUÍLIDES

se de facto, com verdade, Clio

toda-florescente as destilou em minha [mente,

230 cançóes de agradáveis palavras

o proclamarão ao mundo inteiro. 


\section{Odes 14, 14A, 14B}

Da ode 14, epinício dedicado a Cleoptólemo da Tessália pela sua vitória na corrida de cavalos nos Jogos Pétreos - competição local menos conhecida, em honra de Poséidon -, apenas conservamos os 23 versos iniciais, uma tríade completa e escassos vestígios da segunda Estrofe e do segundo Epodo. Colocado no final do livro dos epinícios, na ordenação que o escriba do Papiro de Londres deu ao fólio com os textos desse género, provavelmente por se referir a um festival menor, não é por isso correto integrar o texto nas últimas produções do poeta. Deve aliás tratar-se de uma das composiçôes mais antigas do corpus conservado, e A. Severyns 1933: 36 acreditava mesmo, pese embora a ausência de fontes que o confirmem, que tivesse sido Simónides a ceder ao sobrinho e entáo ainda jovem poeta a possibilidade de celebrar essa vitória, menor pela pouca importância dos jogos em que ocorreu.

O epinício 14 foi, até 1956, o último poema deste género a constar nas ediçôes de Baquílides, até que E. Lobel publicou vários fragmentos atribuídos ao poeta, entre os quais 17 versos do que considerou serem dois epinícios diferentes, que cedo receberam nas ediçóes a numeração de $14 \mathrm{~A}$ e $14 \mathrm{~B}$. Se do primeiro apenas se conservam os vestígios de três versos pouco reveladores, já do segundo conseguimos ler onze versos praticamente completos.

Acreditava E. Lobel que o texto de 14B fosse parte do epinício em honra de Aristóteles de Larissa pela sua vitória na corrida de carros nos Jogos Píticos, o que parecia correto 
depreender do texto conservado. Não obstante, H. Maehler 1982: 302-303 recusava considerar o fragmento parte de um epinício, entendendo-o antes como um poema composto para celebrar a tomada de posse de um qualquer funcionário público de Larissa. Assim resolvia o editor o problema de este texto não ter sido incluído, pelos editores alexandrinos, antes do fragmento 14 , se de facto foi critério de organização o deixar para o final o único poema respeitante a uma competição menor. Esta ideia, contudo, não colheu fortuna crítica, e todos os comentadores e editores aceitam hoje que se trata de um fragmento do género epinício. 


\section{Para Cleoptólemo da Tessália, Pela Quadri- ga nos Jogos Pétreos}

Boa sorte ter recebido da divindade

Estrofe 1

é para os homens o que melhor há.

A Fortuna o nobre reduz

ao nada, se vem insuportável,

e o mau faz brilhar nas alturas,

se avança próspera. Honra,

essa há para uns e para outros;

inumerávei]s são as virtudes dos homens,

Antistrofe 1

mas uma há que as demais supera:

que cada um o que tem em mãos dirija

com um coração justo.

$\mathrm{Nem}$ ] com batalhas plenas de gemidos

se harmonizam o som da lira

e os coros de clara voz,

nem com as festas o estrépito

dos golpes [do bronze]; para cada ação humana, [a ocasião] é o melhor.

Ao que bem procede, há de o deus [fazer prosperar.

Por isso agora, como tributo a Cleoptólemo,

convém que o recinto de Poséidon Pétreo ${ }^{137}$

${ }^{137}$ Apenas o epinício em apreço e um passo de Apolónio de Rodes (Argonáuticas 3.244) informam da existência destas competiçóes locais da Tessália, que deviam ter na sua etiologia o momento lendário em que 
BAQUílides

seja celebrado,

e o afamado [filho] de Pírrico, vencedor na quadriga,

ele que, de hospedeira e justiceira Estrofe 2

[pátria nascido (?)]...

Poséidon teria fundido com o seu tridente as montanhas de Osa e Olimpo - assim surgindo o Vale do Tempe -, de forma a evitar as constantes inundaçôes que assolavam a Tessália. 


\section{$14 \mathrm{~A}$}

por graça] de Diónisos

e [das Musas]...

\section{B. [PARA ARISTÓTELES DE LARISSA ?]}

Héstia do trono dourado, tu que dos afamados Agatocléades ${ }^{138}$, ricos varóes, a grande prosperidade aumentas, desde o teu assento em meio das ruas vizinhas do odorífero Peneu ${ }^{139}$, nos vales da Tessália criadora de rebanhos! Daí também Aristóteles chegou ao muito florido Cirra ${ }^{140}$,

e por duas vezes foi coroado, para glória de Larissa, senhora de cavalos

${ }^{138}$ A família de Aristóteles.

${ }^{139} \mathrm{O}$ mais importante rio da Tessália, em cuja margem direita se localizava a cidade de Larissa.

${ }^{140}$ Referência aos Jogos Píticos, em Delfos. Vd. supra, ode 4, v. 15 e nota ad loc. 
(Página deixada propositadamente em branco) 


\section{Ditirambos}


(Página deixada propositadamente em branco) 


\section{ODE 15}

Em data que ignoramos, o texto que ocupava o primeiro lugar no rolo dos ditirambos de Baquílides terá sido executado em Atenas, hipótese atrativa tendo em conta o discurso final de Menelau, que versa sobre o tema da insolência humana (hybris) e o motivo da gigantomaquia, a luta dos Gigantes contra dos deuses do Olimpo, com derrota para os primeiros, tópico mítico que sabemos frequente nas Panateneias, desde a reorganização desse festival em 566/565 a.C.

É de acreditar que o coro da apresentação original do ditirambo fosse constituído pelos míticos cinquenta filhos de Teano e Antenor. Estamos em pleno contexto épico, no momento anterior às maiores hostilidades em Tróia quando, pela palavra, Menelau e Ulisses buscam ainda resgatar Helena e evitar um banho de sangue, como confirma o resumo que desse episódio faz Apolodoro (3.28-29).

$\mathrm{O}$ episódio tem início in medias res, no momento em que a esposa de Antenor abre aos Argivos os portais do templo de Atena para que peçam à deusa pelo bom desfecho da sua embaixada. Entre os versos 10-24 teria lugar o seu discurso, linhas demasiado fragmentadas para delas retirar qualquer conclusão certa, mas onde os críticos julgaram que poderia haver referência à veste que a sacerdotisa entregara à deusa, a mando de Hécuba, suplicando pela libertação da cidade cercada, conforme descrito na Ilíada (6.297-303). A ser assim, a veste (peplos) encontraria relação com essa outra que, nas Panateneias, era oferecida à estátua de Atena, onde estaria 
gravado um friso com a gigantomaquia. Simbolicamente, portanto, estariam em paralelo o contexto mitológico e o da performance do ditirambo.

Só depois, por entre as lacunas do texto conservado, tem lugar a preparação e a realização da audiência dos visitantes na Assembleia, onde seriam, como se sabe, recusadas as suas propostas de paz. O ditirambo termina com o discurso de Menelau (vv. 50-64), versando sobre valores (deificados) como a Justiça, a Concórdia e a Justiça Divina (Témis), contra as quais tudo deita a perder a Insolência, como fez com os Gigantes do mito.

O ditirambo, disso o acusaram já, terminaria de forma abrupta, suspeitando alguns que não nos tivesse chegado completo. Não obstante, o final da ode 5 e da ode 16, por exemplo, provam ser essa uma técnica poética de Baquílides, que confia no conhecimento mítico da sua audiência e permite que seja ela, de forma altamente criativa, quem retira as suas ilações. 


\section{Os Filhos de ANTENOR, OU O RESGATE DE HELENA $^{141}$}

A esposa veneranda] de Antenor Estrofe 1 semelhante aos deuses, a sacerdotisa de Atena, abriu o sagrado templo] de Palas que incita à luta e as suas portadas] de ouro aos dois embaixadores] dos Argivos, a Ulisses, filho de Laertes, e ao rei Atrida Menel]au ... Teano de cintura [funda]

$\cdots$ Antistrofe 1

... assim lhes falou:

«Estrangeiros, por que à (?)]bem construída [Tróia (?)

... que obteve

com auxílio dos deuses (?)

Epodo 1

(faltam nove linhas do epodo 1)

Estrofe 2

... palavras não secretas e sonoras

aporta aos mortais a sabedoria,

(faltam 11 versos)

(Antistrofe 2)

${ }^{141} \mathrm{O}$ tema, referido na Ilíada (3.205-224 e 11.138-142), constituiria o assunto da tragédia perdida de Sófocles Resgate de Helena. 
eles $^{142}$ (os) conduziam, enquanto seu pai, prudente herói, por inteiro relatava ao rei Príamo

e aos seus filhos a mensagem dos Aqueus.

Por essa altura já os arautos, apressados pela vastidadão da cidade, congregavam as falanges dos Troianos

para a ágora que acolhe o exército. Estrofe 3 Por toda a parte se espalhou clara mensagem. Aos deuses imortais erguendo as mãos, suplicavam que tivesse fim a sua desventura.

Musa, qual o primeiro a dar início às razóes justas? Menelau, filho de Plístenes ${ }^{143}$, com voz sedutora assim falou, com auxílio das Graças de belos peplos:

«Troianos versados na guerra! Antistrofe 3 Zeus, o senhor das alturas que tudo vê, não é para os mortais causa de tão grandes desgraças; antes, na medida, é possível a todos os homens alcançar a retidão da Justiça, da sagrada Concórdia e da sapiente Témis ${ }^{144}$ a companheira: felizes aqueles cujos filhos a escolhem para conviver!

142 Os filhos de Antenor, que deveriam já ter sido mencionados na parte perdida do poema.

${ }^{143}$ É posterior aos Poemas Homéricos, e menos divulgada, a tradição segundo a qual Menelau e Agamémnon seriam filhos de Plístenes, e não de Atreu - versão também atualizada por Baquílides (v. 5).

144 Témis, personificação da justiça divina, era mãe das Horas, da Concórdia (Eunomia) e da Paz (Eirene). 
Já essa outra, que em rápidos lucros e demências Epodo 3 desmedidas floresce, a desavergonhada Insolência ${ }^{145}$, que num ápice a riqueza e o poder de outrem rapina, e logo

o arrasta à mais funda miséria, ela, mesmo os arrogantes filhos da Terra deitou a perder, os Gigantes ${ }^{146}$.»

${ }^{145}$ A Insolência (Hybris), aqui personificada, é a grande responsável por todo o conflito troiano. Menelau tem com certeza em mente, neste ponto, o comportamento impetuoso de Páris ao raptar Helena.

${ }^{146}$ Quando lutaram contra os deuses olímpicos. 


\section{ODE 16}

Em data desconhecida, o segundo ditirambo de Baquílides terá sido executado em Delfos - para aí se inclina a maior parte dos estudiosos -, mas não é de descartar por completo a hipótese de ter sido apresentado em Atenas, teoria apoiada na alusão a Poséidon (v. 19) e a Atena (vv. 20-21). Composto de uma tríade completa, num estado de conservação bastante aceitável, o poema apoia-se na narração de dois mitos, um etiológico e outro com intençóes mais moralizantes.

Num primeiro momento (vv. 1-12; vd. nota 149) o poeta versa sobre a etiologia da execução ditirâmbica em Delfos, o recinto para o qual o poema pode ter sido composto. O mito principal do ditirambo, esse (vv. 13-35), é introduzido sob a forma de uma breve proposição épica. Héracles, que tinha conseguido a máo de Íle, princesa da Ecália, ao vencer Êurito e os seus filhos no tiro com arco, vê essa promessa negada pelo pai da jovem. Anos mais tarde, quando Héracles estava já casado com Dejanira, empreende uma ofensiva contra a Ecália para recuperar Íole, saindo vitorioso. Ao tomar conhecimento do sucedido, movida pelo ciúme, Dejanira recorda que conservava um filtro amoroso que, anos antes, lhe dera o centauro Nesso, no momento em que, depois de a tentar raptar, fora assassinado por Héracles. Havia-lhe dito o centauro que, ao usá-lo com o marido, conseguiria a sua paixão. Mas ocultara que a mistura continha o veneno da Hidra de Lerna, com isso esperando o monstro, no futuro, vingar-se de Héracles. Dejanira recorre 
a esse estratagema, conseguindo com isso que a túnica que embebera nesse filtro se incendeie e com ela queime o corpo de Héracles, que termina voluntariamente morto numa pira, por ele mesmo mandada erguer no alto do monte Etna. Baquílides conclui portanto, na presente composição, o desfecho anunciado por Meleagro quando, na ode 5 (v. 3), tragicamente sugere o nome de Dejanira para esposa de Héracles. Finalmente, o fragmento 64, de atribuição duvidosa a Baquílides (mas que traduzimos nesta edição), narra a luta de Héracles com Nesso, no rescaldo da tentativa de violação de Dejanira pelo último. $\mathrm{O}$ mito em causa foi, a outro nível, desenvolvido por Sófocles nas Traquínias, o que levou a discutir a primazia temporal de um ou de outro texto, sem conclusóes seguras, desde logo porque nem o ditirambo de Baquílides nem a tragédia conseguiram ainda datação segura. 


\section{6. [Héracles (ou Dejanira), PARA DELFOS]}

Irei às terras de Pito (?)], já que

um cargueiro de ouro me enviou, da Piéria ${ }^{147}$, Urânia de belo trono, carregado de afamados hinos para o deus], quando, no florido Hebro, entre feras] se alegra, ou com o cisne ${ }^{148}$ de longo colo, com doçura da sua voz] animando o coração, até a Pito] ele chegar, para colher as flores dos peanes, - ó Apolo Pítio! -, essas que os coros das gentes de Delfos entoam junto ao teu ilustre templo. ${ }^{149}$

Mas antes ${ }^{150}$, cantemos como deixou Antistrofe a Ecália, consumida pelo fogo,

o filho de Anfitriāo, mortal de ardilosos planos, e veio para o promontório que as ondas rodeiam; aí, do seu resgate, a Zeus Ceneu ${ }^{151}$ de vastas nuvens

${ }^{147}$ A morada mítica das Musas.

${ }^{148} \mathrm{O}$ cisne estava consagrado a Apolo.

${ }^{149}$ A Estrofe desenvolve a estância anual mítica de Apolo entre os Hiperbóreos, durante os três meses de Inverno, período durante o qual, em Delfos, se cultuava Diónisos, pelo que se entoavam ditirambos e não peanes.

${ }^{150}$ I.e., antes que Apolo regresse, enquanto é tempo de ditirambos.

${ }^{151} \mathrm{O}$ cabo Ceneu situava-se a noroeste de Eubeia, e aí recebia culto Zeus. 
nove touros de grave mugir se dispôs a imolar, dois ao deus que revolve os mares e abala a terra ${ }^{152}$, e à donzela de olhar seguro,

a virgem Atena,

uma novilha de altos cornos ainda por jungir.

Foi quando um deus que se não pode combater ${ }^{153}$

a Dejanira inspirou, cheio de lágrimas,

um plano astuto, ao tomar ela

conhecimento da dolorosa notícia:

que Ílo de níveos braços

o filho de Zeus, destemido na luta,

enviava como esposa para o seu refulgente palácio.

Ah infeliz! Desgraçada! Que foi ela planear!

O todo-poderoso ciúme a deitou a perder, juntamente com o tenebroso véu

que escondia as coisas do porvir, quando, nas róseas margens do Licormas ${ }^{154}$, recebeu de Nesso esse fatal prodígio.

152 Poséidon.

${ }^{153} \mathrm{O}$ «deus que se não pode combater» (daimon amachos) pode referir-se a Eros ou, a um nível mais geral, ao Destino, de novo convocado como responsável pelo "fatal prodígio" (daimonion teras) do v. 35.

154 Nome antigo do rio Eveno que, nascendo perto do monte Etna, corre pela Etólia e vai desaguar no Golfo de Corinto. 


\section{ODES 17 E 18}

Comentamos em conjunto os dois mais importantes e estudados ditirambos de Baquílides, porquanto ambos versam sobre a figura táo importante à época, sobretudo em Atenas, de Teseu. Testemunhos de outros autores, bem assim das artes plásticas e da arquitetura, confirmam a importância crescente que esse herói, na sequência do destaque que o século anterior dera a Héracles, começava a ter na Ática, sobretudo após a vitória grega contra os Persas em Maratona (490 a.C.), contexto que simbolicamente culminaria com a decoração, por Mícon e Polignoto, dos trabalhos de Teseu no Hefestéion, erigido algures entre 449-440 a.C., e com a trasladação dos supostos restos mortais do herói para a ágora (Plutarco, Teseu 36).

A ode 17, encabeçada no Papiro de Londres pela epígrafe Os Jovens ou Teseu, foi ao que tudo indica composta para ser executada por cidadáos de Ceos em Delos, como se depreende dos três últimos versos do texto (vv. 130-132). A relação com Atenas, portanto, mais não é do que temática. $\mathrm{O}$ texto desenvolve a narrativa da viagem por mar de Teseu e os jovens atenienses para Creta (vd. nota 155), onde venceriam o Minotauro, durante a qual Minos póe em causa a ascendência divina do herói e o desafia a lançar-se ao mar, para recuperar um anel que para lá havia atirado. Debaixo de água, Teseu é recebido por Poséidon e Anfitrite no palácio de ambos e por eles trazido de novo à superfície. R. C. Jebb 1905: 229 datou o poema da década de 70 do século $\mathrm{V}$ a.C., enquadrando-o no contexto do referido interesse pela 
figura de Teseu. Já A. Severyns 1933: 57 sqq., concordando com o primeiro estudioso quanto à data do poema, tende a interpretá-lo à luz da recém-formada Confederaçấo de Delos (478/477 a.C.), aproximando-o em específico dos primeiros anos desse pacto e com isso chegando ao lapso temporal 478-470 a.C. para a sua datação relativa do poema.

Mas esta datação tem sido posta em causa nas últimas décadas, sendo tendência dos estudiosos ora fazê-la recuar no tempo até à década de 90 (H. Maehler 1997: 114-126 e 2004: 173-175), ora considerar o texto já do início da década de 60 (D. A. Schmidt 1990: 29-31). Para Maehler, os testemunhos iconográficos deste episódio, detetáveis desde o século VII a.C., provam de forma suficiente a sua antiguidade; e é baseado num deles, uma taça ática de figuras vermelhas assinada pelo oleiro Eufrónio e atribuída ao pintor Onésimo, de cerca de 500/490 a.C. (Louvre G104), com semelhanças evidentes com o texto de Baquílides, que estabelece para o último o terminus post quem de 490 a.C. D. A. Schmidt 1990, por seu turno, depois de refutar o limite mais recuado defendido por A. Severyns 1933 (478 a.C., relembramos, coincidindo com o início da Confederaçáo de Delos), começa por considerar que o texto é compatível com qualquer fase da vida do poeta e que a relaçáo do mito com Atenas não pode ser o único argumento a relacioná-lo com uma estadia de Baquílides nessa cidade, porquanto outras comunidades gregas tinham relaçóes antigas com o culto de Teseu (D. A. Schmidt 1990: 29-30). E de seguida acrescenta coincidências linguísticas com Os Persas de Ésquilo que o levam a suspeitar, com alguma convicção, que o ditirambo date de 469 a.C. ou pouco depois.

Igualmente complicada tem sido a datação da ode 18. O episódio em causa, nessa composiçáo cujo único título 
conservado é o genérico Teseu, prende-se com a chegada do herói à Ática, em busca das suas origens, e também por isso é plausível que a ode tenha sido executada numa festa de Atenas. Uma das hipóteses mais creditadas imagina o poema representado numa cerimónia de iniciação efébica na idade adulta, dos quais Teseu seria o melhor paradigma mítico (vd. infra, nota 177). A. Severyns 1933: 56 sqq. datou o texto, à semelhança da ode 17 , do período entre 478-470 a.C., considerando-o no entanto, pelo estilo, mais recente do que aquele. Com esta opinião concorda grande parte dos especialistas, entre os quais D. Arnould 2001: 222, que situa o texto por volta do ano de 474 a.C., referindo que ele teria sido executado num contexto nacionalista muito específico; com efeito, durante o arcontado de Fédon (476475 a.C.) e no rescaldo da vitória ateniense em Maratona (490 a.C.), o oráculo de Delfos ordenara aos Atenienses que trasladassem para a sua cidade as supostas cinzas de Teseu, antes sepultadas na ilha de Ciros, empresa realizada por Címon (cf. Plutarco, Teseu 36). Assim, poderia esse marco em concreto ter influenciado diretamente a produçấo do ditirambo de Baquílides, hipótese coerente e tentadora, contudo não segura. Alguns estudiosos defenderam que era de baixar a data do ditirambo, baseando-se em interpretaçóes políticas e rituais, vendo no texto alusóes a figuras da época e assim chegando a datas como 460-455 (J. P. Barron 1980: 1-8) ou 458 (H. Maehler 2004: 190-191).

Se a ode 17 nos situa perante o expoente máximo da arte narrativa impressionista, mas também de sabor épico de Baquílides, a ode 18 surpreende sobretudo pela sua forma. Sem narrador, apenas um Coro e Egeu, o velho rei de Atenas, esperam e comentam a chegada anunciada de um forasteiro desconhecido (Teseu), de quem se vão narrando as façanhas 
que se ouviram contar. Têm os estudiosos questionado se Baquílides se terá deixado influenciar pelo género dramático ateniense, que por esses anos começava a atingir fama, ou se, ao invés, fez um esforço propositado de dotar o seu poema de um tom mais arcaizante, próprio do tempo em que o ditirambo e a tragédia não tinham seguido ainda caminhos autónomos. Seja como for, a ode 18 é o único exemplo conhecido de um ditirambo estrófico e inteiramente dialogado, não triádico (isto é, não organizado na lógica Estrofe, Antístrofe e Epodo), além de constituir a primeira ocorrência literária conservada dos trabalhos de Teseu. 


\section{Os Jovens ou Teseu. [aos de Ceos, para Delos]}

O navio de escura proa que levava Teseu, Estrofe 1 seguro ante o grito de combate, e com ele duas vezes sete jovens notáveis dos Iónios, seguia rasgando ondas pelo mar de Creta; ${ }^{155}$ pois [sobre] a vela que brilha ao longe tombavam as brisas do Bóreas, obra da ilustre Atena que agita a égide. Então inflamaram o coração a Minos os sagrados dons da deusa de amável diadema, Cípris; a sua mão não mais pôde afastar de uma donzela, e logo tocou as suas faces brancas. Gritou Euribeia ${ }^{156}$ pelo descendente de couraça de bronze de Pandíon ${ }^{157}$;

${ }^{155}$ Estamos perante um exemplo acabado de início in medias res. Minos, rei de Creta, tinha saqueado Atenas em vingança do assassinato do seu filho Androgeu, quando este triunfara num festival atlético local. Para resolver o impasse do cerco sobre a cidade, os Atenienses comprometeram-se a enviar regularmente sete rapazes e sete raparigas para Creta, onde seriam sacrificadas ao Minotauro. Da terceira vez que se cumpria essa obrigação, o próprio Minos se deslocou a Atenas para escolher as vítimas, e entre elas estava Teseu, que havia chegado entretanto à cidade (o assunto da 18).

156 Pode tratar-se da mesma donzela que casou com Télamon e deu à luz Ájax (vd. ode 13), da qual Plutarco (Vida de Teseu 29) diz que se relacionou amorosamente com Teseu.

157 Teseu é dito descendente de Pandíon porquanto este era pai de Egeu, pai mortal do herói. Na realidade, Baquílides serve-se de ambas 
apercebeu-se então Teseu,

os negros olhos sob as pálpebras

lhe giraram, do seu peito

tomou conta uma dor terrível

e disse: «filho de Zeus supremo,

virtuoso já não diriges

dentro de teu peito o ânimo;

cessa, herói, essa arrogante violência!

O que o destino todo-poderoso dos deuses

Antistrofe 1

para nós determinou, e a balança da Justiça

faz pender, a nossa predestinada sorte,

essa cumpriremos, quando quer que venha;

agora tu, contém a tua onerosa

intenção. E se uma nobre mulher

te gerou, ao leito de Zeus sob os cumes do Ida ${ }^{158}$

unida - a filha de amável nome

de Fénice - como o mais nobre

dos mortais também a mim

a filha do abastado Piteu ${ }^{159}$

me gerou, ao deitar-se com o marinho

Poséidon, e dourado

véu (?)] então lhe deram

as Nereides de tranças violáceas.

Por isso, polemarco dos Cnóssios ${ }^{160}$,

as versóes para a paternidade de Teseu: ora Egeu, ora Poséidon - a cujos palácios marinhos, no poema, o herói é desafiado a descer.

${ }^{158}$ Minos fora gerado por Europa quando Zeus, transformando-se em touro, raptou essa mulher, filha de Fénice, e a levou para o Ida (o monte que há em Creta com esse nome, não o da Tróade).

159 Etra.

${ }^{160}$ Outra designação para os Cretenses. 
peço-te que contenhas a tua insolência, causa de muitos gemidos; pois não desejaria a imortal e adorável luz da Aurora de novo contemplar, se algum destes jovens tu tivesses tomado contra sua vontade; antes, a força das nossas mãos mostraremos; e o futuro, a divindade o decidirá.»

Assim falou o herói, valente lanceiro; Epodo 1 admiraram-se os que iam embarcados com a audácia inaudita desse mortal; ao genro de Hélios ${ }^{161}$ irritou o coração, e logo ele urdiu um inaudito plano e disse: «muito poderoso Zeus meu pai, escuta! Se em verdade a donzela Fenícia ${ }^{162}$ de alvos braços para ti me gerou,

55 agora mesmo envia do céu um relâmpago de cabeleira de fogo, veloz, indício bem reconhecível. E se a ti uma mulher de Trezena, Etra, te deu à luz, para Poséidon, o deus que sacode a terra,

60 este dourado e esplêndido adorno que a minha máo enfeita ${ }^{163}$ recupera das profundezas do mar, lançando com coragem o corpo às moradas de teu pai. Assim saberás se escuta a minha súplica o filho de Cronos,

${ }^{161}$ Pasífae, esposa de Minos, era filha de Hélios (o Sol).

162 Europa.

${ }^{163} \mathrm{O}$ desafio lançado por Minos consiste em recuperar um anel do fundo do mar, feito a que Baquílides não faz referência quando Teseu ressurge das águas. 
senhor do trovão que tudo governa.»

Escutou a sua súplica irrepreensível o muito

\section{[poderoso Estrofe 2}

Zeus, e para Minos, seu filho querido, fez nascer

uma honra evidente, e por isso quis

a todos torná-la visível,

lançando o relâmpago. Quando esse prodígio

grato ao coração viu, a mão ergueu

ao ilustre éter o herói firme na guerra,

e então disse: «Teseu, com clareza

vislumbras (?)] estes dons de Zeus;

quanto a ti, lança-te agora ao mar

de profundo ressoar; e o Crónida

teu pai, o soberano Poséidon,

há de conceder-te a mais elevada

reputação sobre a terra de farto arvoredo.»

Assim falou. Mas nele não recuou

o ânimo, antes,

nos bem construídos estrados

apoiado, saltou e o marinho

recinto o acolheu favorável.

Admirou-se o filho de Zeus no íntimo

do seu coração, e ordenou no curso do vento

manter a bem trabalhada nau.

Mas o destino preparava distinto caminho.

Avançava o madeiro veloz; empurrava-o

o vento Bóreas, soprando-lhe por trás.

Estremeceu [todo (?)] o grupo

de jovens Atenienses quando

o herói se lançou ao mar, 
e dos seus olhos semelhantes a lírios, profetas de duro desfecho, caíram lágrimas.

Mas uns golfinhos que vivem no mar

num ápice levaram o grande

Teseu à morada de seu hípio pai;

100 e foi assim que chegou ao palácio dos deuses. Aí, sentiu medo ao ver as filhas ilustres do afortunado Nereu $^{164}$ : é que de seus admiráveis membros refulgia um lampejo

105 como que de fogo, e em volta dos seus cabelos serpenteavam cintas entrançadas em ouro; entre danças, deleitavam o coração com os húmidos pés.

Viu a esposa querida de seu pai,

110 a venerável Anfitrite ${ }^{165}$ de olhos de vaca, nas amáveis mansóes que eram suas. Ela mesma lhe vestiu uma túnica purpúrea (?)

e em seus fartos cabelos aconchegou uma grinalda irrepreensível,

115 que antes, por ocasiáo do seu casamento, lhe ofertara a astuta Afrodite, ensombrada de rosas.

Nada que as divindades concedam é inacreditável para os mortais de espírito sensato. Junto da nau de fina popa reaparaceu. Oh!,

120 em que pensamentos o cnóssio estratega foi defraudado quando, regressando seco do mar,

${ }^{164}$ As Nereides, ninfas marinhas filhas de Nereu.

165 Anfitrite era a esposa de Poséidon e filha de Nereu. 
prodígio para todos, lhe brilhavam

pelos membros as dádivas dos deuses;

as donzelas de ilustre trono ${ }^{166}$

com alegria renovada

gritaram, e o pélago inteiro

se fez ouvir. Os jovens, a seu lado,

entoaram um péan com voz amável.

Soberano de Delos! Com os coros de Ceos

acalentando agora o teu coração,

concede-nos a sorte das benesses que dão os deuses.

${ }^{166}$ Refere-se Baquílides às jovens que iam embarcadas - como parece sugerir a mençáo da "alegria renovada" - ou às Nereides, que trouxeram Teseu de volta à superfície - leitura mais coerente tendo em conta o epíteto «de ilustre trono»? Sem certezas, preferimos a primeira leitura - embora a opção por uma ou por outra em nada comprometa a traduçáo do verso -, desde logo por nos parecer mais coerente com o estilo de Baquílides, neste ponto, o regresso ao assunto e aos protagonistas da primeira parte do poema. 


\section{Teseu [para os ATENiEnSes]}

\section{[CORO]}

Rei da sagrada Atenas,

dos Iónios de requintado viver soberano, porque entoou ainda há pouco a trompeta

de boca de bonze uma melodia de guerra?

Será que da nossa terra

algum inimigo rodeia as fronteiras,

um homem comandante de exércitos?

Ou ladrōes que planeiam desgraças

contra a vontade dos pastores

rapinam pela força rebanhos de ovelhas?

Ou que outra coisa te molesta o coração?

Fala! Creio que se algum dos mortais

do auxílio de valentes

jovens dispóe, esse és tu,

15 filho de Pandíon e Creúsa ${ }^{167}$.

\section{[EGEU]}

Há pouco chegou um arauto, percorrendo Estrofe 2

a pé o vasto caminho do Istmo;

${ }^{167}$ Em todas as demais fontes, Egeu é filho de Pandíon e Pília, filha de Pilas, rei de Mégara. Poderia a tradição não estar ainda completamente fixada ao tempo da composição do poema, razão pela qual Baquílides atribui a maternidade de Egeu a Creúsa, tradicionalmente a esposa de Xuto que gerou, com Apolo, Íon, protagonista da homónima tragédia euripidiana. 
inauditos feitos ${ }^{168}$ conta de um poderoso

homem; que ao arrogante Sínis ${ }^{169}$

deu morte, em força o mais excelente

dos mortais, o que do Crónida Liteio

que sacode a terra é filho;

à porca matadora de homens nos vales

do Crémion ${ }^{170}$ e ao ímpio

Scíron ${ }^{171}$ assassinou também;

à escola de combate de Cércion ${ }^{172}$

pôs cobro, e o poderoso martelo

de Polipémon Procoptas ${ }^{173}$ deixou cair,

ao defrontar por fim um homem

mais valente. Receio pelo fim de tudo isto!

\section{[CORO]}

Quem é e de onde vem esse homem,

Estrofe 3

${ }^{168}$ Baquílides narra apenas cinco trabalhos de Teseu, na sua viagem de Trezena para Atenas, quando a maior parte das fontes considera seis, acrescentando à lista a morte de Perífates, o filho de Hefestos que em Epidauro dava morte aos viajantes com a sua maça.

169 Gigante que assassinava os viajantes de forma particularmente cruel: atava os seus membros a pinheiros vergados, que depois soltava, assim destroçando o corpo das suas vítimas.

${ }^{170}$ Entre Corinto e Mégara.

${ }^{171}$ Filho de Pélops ou Poséidon, tinha-se fixado em Mégara. Obrigava os transeuntes a lavar-lhe os pés, durante o que os lançava ao mar, onde uma tartaruga gigante os devorava.

${ }^{172}$ Cércion tinha uma escola de combate (ou palestra) entre Mégara e Elêusis, na qual obrigava os que junto de si passavam a lutar consigo para, depois de vencidos, lhes dar morte.

${ }^{173}$ Apenas Baquílides designa assim este monstro (à letra «o que corta com o martelo»), quando as restantes fontes lhe dão o nome de Procrustes. Seria descendente de Polipémon («o que é causa de muitas dores»), e a tradição conta que atacaria os viajantes entre Mégara e Atenas, atando-os deitados numa plataforma onde esticava os mais pequenos e cortava aos mais altos as partes que sobravam. 
acaso diz, e que equipamento traz?

Será que com armas de guerra

conduz um numeroso exército?

Ou sozinho, com os companheiros

apenas ele avança ${ }^{174}$, viajante perdido

em terra estrangeira,

de tal modo forte, valente

e destemido que à poderosa

força de tais homens

pôs fim? Um deus por certo o incita

a fazer cumprir a justiça aos injustos;

pois em verdade não é coisa fácil

sempre agir sem cair em desgraça!

Tudo, no vasto curso tempo, se cumpre.

\section{[EGEU]}

Dois homens apenas o acompanham,

diz ele, e que aos ombros resplandecentes

traz uma espada ${ }^{175}$ [de punho de marfim],

duas lanças polidas nas mãos

e um bem trabalhado casco lacónio

em volta da cabeça de cabeleira de fogo;

${ }^{174} \mathrm{Na}$ versão original da lenda, Teseu faria a viagem para Atenas sozinho, embora a situação tenha mudado com o tempo. É possível que a pintura de vasos, com as suas exigências de inclusão de mais figuras por questôes de equilíbrio espacial, tenha criado uma tradiçáo que depois Baquílides seguiu no seu ditirambo (cf. v. 46).

175 Antes de partir para Atenas, Egeu deixara em Trezena uma espada cravada numa rocha e prescriçóes a Etra para que apenas revelasse a Teseu a sua paternidade quando fosse forte o suficiente para a remover e ir em busca do pai. É isso que o jovem faz ao completar dezasseis anos: segue para Atenas, pelo caminho marítimo do Istmo, que nessa altura estava impestado de criminosos, pois que Héracles, o outro herói justiceiro, era por esses tempos cativo de Ônfale, na Lídia. 
uma túnica da cor da púrpura

em redor do peito, e uma clâmide

de lã da Tessália. Nos seus olhos

lampeja a vermelha chama

de Lemnos ${ }^{176}$; é ainda um rapaz,

na flor da juventude ${ }^{177}$, mas nos jogos de Ares

tem sempre a mente, na guerra e

nos golpes do bronze na batalha;

e busca a amante de esplendores, Atenas.

${ }^{176}$ A expressão «fogo de Lemnos», que cedo terá passado a designar poeticamente um olhar inflamado, deve-se ao famoso vulcáo Mosiclo, que nessa ilha se localizava.

177 Teseu é caraterizado como um efebo ateniense, desde logo pela clâmide (manto curto usado por efebos e soldados, elaborado com lã da Tessália ou da Macedónia), o que levou os estudiosos a considerarem a possibilidade de o ditirambo ter sido apresentado numa cerimónia de iniciação guerreira efébica. 


\section{Ode 19}

Não dispomos de dados que nos permitam situar no tempo a ode ditirâmbica 19 , embora tudo leve a crer que ela tenha sido apresentada num grande festival ateniense, provavelmente as Grandes Dionísias, que tinham lugar em finais de março. Por isso pensou A. Severyns 1933: 65-66 que seria coerente integrá-la no que considerava o período ateniense do poeta (485-476 a.C.), por razóes temáticas e também formais. Com efeito, o mito tratado prende-se com as façanhas de Io, metamorfoseada por Hera em vaca (vd. infra, notas $178,180,181)$, tópico da predileção dos artistas e do público ateniense no primeiro quartel do século $\mathrm{V}$ a.C., como provam as tragédias Suplicantes e Prometeu Agrilhoado - a primeira de Ésquilo, a segunda a ele atribuída mas de autoria cada vez mais disputada - e a pintura de vasos. H. Maehler 2004: 205, considerando que o ditirambo de Baquílides deve ser posterior às duas tragédias referidas - por seguir a versão mais antiga da pintura de vasos, que representa Io totalmente volvida em forma animal (B. 19.16) e não com forma híbrida, como faz o dramaturgo (Suplicantes, vv. 586570) - estabelece como terminus ante quem do poema o ano de 460 a.C.

Quanto à estrutura, considerava Severyns que o ainda longo proémio da primeira Estrofe (vv. 1-14), pouco comum nas odes ditirâmbicas - que costumam iniciar logo com a narrativa mítica -, podia denunciar que Baquílides se apresentava por primeira vez ao público ateniense, com isso considerando que a ode deve ser anterior no tempo às odes 17 e 18. 


\section{IO, PARA OS ATENIENSES}

Abrem-se incontáveis caminhos

de imortais melodias

para quem tenha recebido

os dons das Musas da Piéria,

e as donzelas de pálpebras violáceas,

as Graças portadoras de grinaldas,

tenham coberto de honra

com seus hinos. Entrelaça agora

algo novo, na muito amável

e afortunada Atenas,

afamado talento de Ceos!

Convém que o melhor caminho

percorras, já que de Calíope

recebeste eminente prémio.

Em tempos (?)], ao abandonar

Argos rica em cavalos, pôs-se em fuga a áurea vaca por conselho do supremo Zeus de poder imenso, a filha de dedos róseos de Ínaco, ${ }^{178}$

quando a Argo, vigilante de todos os lados Antistrofe 1

${ }^{178}$ Io (a filha de Ínaco), sacerdotisa de Hera, foi seduzida por Zeus. Para proteger a sua conquista, o pai dos deuses transformou a jovem numa vaca branca. Hera, movida pelo ciúme, exige ao esposo que lhe ofereça esse animal como presente, deixando Io aos cuidados de Argo, monstro de forma humana que a iconografia representa ora com três, ora com uma infinidade de olhos por todo o corpo. Para libertar a donzela, Zeus encomenda a tarefa a Hermes, o seu mensageiro. 
com esses olhos que não conhecem fadiga, ordenou a grande soberana de peplo dourado, Hera, que sem intervalo e sem sono essa novilha de belos chifres vigiasse; e nem o filho de Maia ${ }^{179}$ logrou, nos dias de clara luz, iludi-lo, ou nas noites sem mácula. Então aconteceu, [no fulgor da luta, o veloz mensageiro [de Zeus dar morte [ao terrível filho da Terra de robusta descendência [com uma pedra, a Argo; ou então[cerraram seus olhos terríveis impronunciáveis preocupaçóes; ou as Piérides cultivaram [com doce melodia a cura das suas penas [intermináveis. ${ }^{180}$

Para mim, seja como for ${ }^{181}$, Epodo 1 mais prudente [é contar o que convém, quando junto do Nilo florido

40 Io chegou, picada [por um moscardo, levando já um filho [de Zeus no ventre (?),

${ }^{179}$ Hermes.

${ }^{180} \mathrm{O}$ poeta recolhe as diversas explicaçóes para dominar Argo: ou Hermes o cegou com uma pedra, ou o adormeceu por via de uma canção, ou ainda foi o próprio monstro quem se deixou dormir pelos cuidados que o preocupavam.

${ }^{181}$ Não optando, à partida, por qualquer versão, Baquílides prefere contar a descendência de Io, por via de Épafo, pai de Líbia; esta última, unida a Poséidon, engendrou Agenor, pai de Cadmo, por sua vez pai de Sémele, a mãe de Diónisos. O poema termina, portanto, com a genealogia mítica do deus titular dos próprios festivais ditirâmbicos. 
Épafo, e aí [o deu à luz (?),

ao soberano [dos Egípcios] de vestes de linho, florescente em suprema [honra,

e proeminente [linhagem] de mortais [fez nascer.

Dela vem também o descendente de Agenor,

o que em [Tebas] das sete portas

gerou] Sémele - Cadmo -,

a que ao deus que dirige as Bacantes,

Diónisos, deu à luz, [das ilustres festas

e dos coros portadores de grinaldas [o senhor. 


\section{OdE 20 (+ FR. 20A)}

O último poema conservado no Papiro de Londres recebe a epígrafe Idas e trataria, quando completo, do mito de Idas e Marpessa. Eveno, rei de Plêuron, impedia por muito tempo o casamento da filha, Marpessa, obrigando os seus pretendentes a competir consigo na corrida de carros, ao cabo do que, derrotando-os, os assassinava. A situação mudou quando Idas recebeu do próprio Apolo um carro puxado por cavalos alados, com o qual venceu Eveno, que, humilhado, se lançou ao rio Licormas - que, a partir de entáo, passou a chamar-se pelo seu nome. Mais tarde, Apolo deseja tomar Marpessa para si, encontrando a feroz concorrência de Idas. Dando-lhe Zeus a possibilidade de escolher entre um e outro pretendente, Marpessa optou pela companhia do mortal, receando que, na sua velhice, Apolo a abandonasse.

Da ode 20 apenas se conservam os onze primeiros versos, nos quais Baquílides contextualiza a sua cançáo no panorama coral de Esparta, descrevendo a dança das donzelas que terão celebrado as bodas do casal mítico. Talvez por isso houve quem tenha considerado o poema um epitalâmio, modalidade da poesia coral destinada às celebraçóes de casamentos, embora possa simplesmente estar em causa o manuseio artístico especial do mito e do género ditirâmbico por parte do poeta.

Quanto ao fragmento 20A, provavelmente mas sem seguranças um encómio (vd. infra, nota 210), ele recua atrás no mito, ao tempo em que Marpessa suplicava ao seu pai por um esposo e a todas as peripécias que conduziriam à 
união com Idas. Relacionados com Esparta estão também os fragmentos 60 e 61 Maehler, cuja atribuição a Baquílides é, no entanto, muito polémica. Trata-se de dois fragmentos líricos que o seu primeiro editor timidamente atribuía ao poeta, mas que C. M. Bowra (recensão a A. Severyns 1933: CR 47 [1933] 240) preferia atribuir a Simónides. Ainda assim, na edição teubneriana de B. Snell, H. Maehler ${ }^{9} 1970$ : LIII-LV, de novo foi defendida a atribuição ao nosso poeta.

Todos estes textos, juntamente com a ode 9, têm sido indicados pelos estudiosos como mostra do trabalho poético de Baquílides durante o exílio no Peloponeso, esse de que apenas Plutarco nos dá notícia (vd. Introdução). Mas, uma vez mais se diga, não é forçoso considerar essa relação direta, já que o poeta pode simplesmente ter enviado as suas cançôes para serem executadas na sua ausência. 


\section{IDAS, PARA OS LACEDEMÓNIOS}

Outrora, em Esparta [de vastos terrenos, as louras [filhas] dos Lacedemónios esta mesma melodia [entoaram, na altura em que Idas de audaz coração levava pela mão a donzela de belas faces, Marpessa [de cabelo violáceo (?), quando escapou à morte [certa e um carro o soberano dos mares, Poséidon, [lhe concedeu, ${ }^{182}$

e cavalos semelhantes aos ventos, para a bem construída Plêuron [o enviando, e para junto do filho [de Ares] de áureo escudo

(falta a continuaçâo)

${ }^{182}$ A reconstruçáo dos versos 7-8 que seguimos em tradução, proposta por Maehler na edição que tomámos por referência, mais não é do que uma sugestấo especulativa e miticamente coerente. Sobre o mito de Marpessa, vd. texto introdutório e infra, fr. 20A. 


\section{ODES 21-29 (FRAGMENTOS DOS DITIRAMBOS)}

Como se disse já na Introdução, apenas a organização das odes ditirâmbicas obedece, no Papiro de Londres, a um princípio claro: a ordem alfabética do seu título ou epígrafe. Por exemplo, o primeiro ditirambo conservado (ode 15) ocupa essa posição devido à epígrafe grega Antênoridai he Helenês Apaitêsis ("Os filhos de Antenor, ou o resgate de Helena"), e o último (ode 20) I Idas. Fica desta forma claro que muitos outros ditirambos se seguiriam, e os editores foram recuperando, dos fragmentos que Kenyon deixara dispersos na primeira edição, restos de outros poemas do mesmo género. Entre outros, cujo estado lacunar não permite grandes ilaçoos, Baquílides terá composto um ditirambo dedicado à figura de Cassandra (ode 23), outro sobre Meleagro (ode 25) - figura da predileçâo do poeta, à qual dá o destaque que lemos na ode epinícia 5 -, além de outros que versariam sobre figuras como Quíron (ode 27) ou Orfeu (ode 29). Para estes textos, que na medida do possível em seguida apresentamos em tradução, procurámos que as notas fornecessem os esclarecimentos míticos possíveis. 
como os Mantineios, que levam gravado

o tridente de Poséidon nos brônzeos escudos

bem trabalhado...

... fugir (?) ...

\section{2 [TÍTULO DESCONHECIDO]}

... com [alegria (?)

\section{CASSANDRa [PARA OS ATENIENSES?] ${ }^{184}$}

a flor [de homens valerosos (?)] da sagrada Atenas $* * *$

... divino (?)] santuário

$* * *$

... um som ressoa

${ }^{183}$ Não sendo sequer seguro que o fragmento fosse parte de um ditirambo, Blass sugeriu que integrasse o poema desse género que recebe o título Cassandra (n. ${ }^{\circ} 23$ ), e que a referência às tropas Mantineias fizesse parte da profecia da princesa, no momento em que enumerava as tropas gregas.

${ }^{184}$ A existência de um ditirambo de Baquílides sobre o tema de Cassandra é confirmada por um comentário de Porfírio a Horácio (Odes 1.15). 
com o melodioso] sopro das flautas ${ }^{185}$

$* * *$

... triplamente (?)] enroscado

... e quando...

$* * *$

a graça convém...

$* * *$

... dos peanes (?) ...

$* * *$

... de longa ponta (?)

$* * *$

[Iế!]

\section{4 [TÍTULO DESCONHECIDO]}

... bem trabalhado (?) ...

... eu (?) apareço (?) ...

... de mente (?) ...

... mulher (?) ... filho (?) ${ }^{186}$

${ }^{185} \mathrm{O}$ texto desenvolveria uma situação de paz enganosa em Tróia, cenário das profecias de Cassandra.

${ }^{186} \mathrm{O}$ contexto não é seguro, mas é possível que se trate de um filho dirigindo-se ou falando da mãe. A lenda do sacrifício voluntário da filha de Erecteu, ou Aquiles a conversar com a mãe (Tétis) ou o pai (Peleu) são apenas duas hipóteses avançadas. 
BAQUílides

o espírito domine ...

pois não há, para o homem [a quem as justiceiras

Moiras com a sua [roca] de ouro

tenham deliberado causar-lhe [mal (?),

10 qualquer fuga, e nem que com brônzeas [muralhas]

a casa fortificasse] a conservaria um indivíduo... prosperidade e reputação.

Isto disse o esplêndido [herói; espantaram-se (?) todos. Então se lançou desde...

15

... pé (?) ... 


\section{5. [Meleagro ?] ${ }^{187}$}

... armada que um deus inspira...

... de variegados...

... péan...

$\ldots$

$\ldots$

... santuário de Ártemis (?)...

... de brancos...

... voz...

... muito corajoso matador de feras ${ }^{188} \ldots$

... que encanta os mortais...

a noite (?) de escuro diadema

e para os que habitam sobre a terra ligeiras...

... ao filho de Zeus (?)...

${ }^{187}$ Sobre o mito de Meleagro, e o episódio da caçada do javali de Cálidon, vd. supra, ode 5 (texto introdutório e vv. 11-135). O presente ditirambo, na parte que dele conservamos, procederia à descrição das lutas contra o animal.

${ }^{188} \mathrm{O}$ epíteto «matador de feras", como a designação "filho de Zeus» (v. 19), devem remeter para Héracles, que, à semelhança da ode 5, desempenharia um papel importante neste ditirambo. 
Baquílides

... subjugado por muitas súplicas

... aos deuses (?)...

... densa...

... de homens...

... todo-poderoso (?)...

25

descendente de Anfitriāo ${ }^{189}$...

... das muralhas

... ressoou (?) o éter...

Clítion e Procáon ${ }^{190}$...

30

... bem nutrido (?)...

${ }^{189}$ Héracles ou, mais provavelmente, Iolau ou Íficles, descendentes de Anfitrião que a tradição inclui entre os caçadores de Cálidon.

${ }^{190}$ Filhos de Téstio e, como tal, irmáos de Altaia e tios de Meleagro. 


\section{6. [PAsífae ?] ${ }^{191}$}

Pasífae

Cípris nela [fez nascer (?)

o desejo...

pelo filho de Eupálamo ${ }^{192}$,

ao mais hábil dos artífices,

a Dédalo, revelou [o seu indizível (?)

mal. Juramentos de fidelidade [tomou

e ordenou-lhe que construísse [uma vaca de madeira

para ungir [ao vigor] do touro [o seu corpo,

às ocultas do [leito (?)] que partilhava

com Minos, o que domina com o arco,

${ }^{191}$ Minos, no contexto das lutas com os irmãos pelo poder de Creta, pedira a Poséidon, para legitimar o seu direito ao trono, que fizesse sair do mar um touro, o qual prometia sacrificar. Negando-se posteriormente a cumprir o dito sacrifício, o deus dos mares enfureceu o animal e fez com que Pasífae, a filha de Hélios e Perseide, sua esposa, por ele se apaixonasse. Segundo outra versão, que parece ser a que segue Baquílides (vv. 3-4), teria sido Afrodite a responsável pelo desejo de Pasífae, fosse pelo facto de essa mulher ter descuidado o seu culto, fosse como forma de vingança contra Hélios, que tinha revelado a sua realação com Ares a Hefestos. O ditirambo de Baquílides desenvolveria, na parte conservada, o estratagema de Pasífae para se aproximar do touro: pedir a Dédalo, o mítico artesão, que construísse uma vaca de madeira, dentro da qual se ocultaria para atrair a atenção do animal. Desta união de cariz zoófilo nasceria, como é do conhecimento comum, o Minotauro.

192 Pai de Dédalo. À letra, o seu nome significa «o de hábeis mãos». 
BAQUílides

o chefe dos Cnóssios.

Mas ele, quando soube da história,

15 foi tomado de preocupação; [pois temia

... da esposa... 


\section{7. [Quíron ?]}

\section{col. II}

tocando a sua loura cabeça,

o prudente Filírida ${ }^{193}$ lhe dizia:

«declara que há de ruborescer Escamandro ${ }^{194}$,

assassinando os amantes da guerra

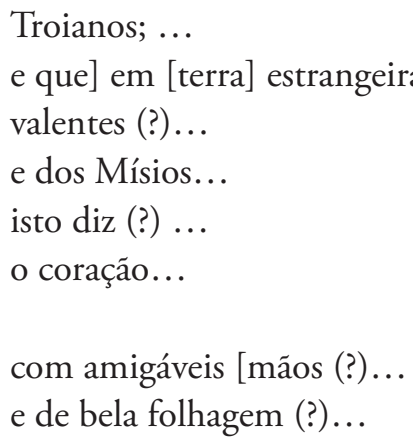

${ }^{193}$ As linhas conservadas consistiriam num discurso profético de Quíron para Aquiles, no momento em que o ainda jovem Pelida estaria a cargo do centauro. As profecias dizem respeito, na parte conservada, à destruiçấo de Tróia (vv. 36-38) e à derrota dos Gregos na Mísia, às mãos de Télefo, no regresso da campanha troiana (vv. 39 sqq.). O último episódio é referido por Píndaro (Ístmicas 8.49), sendo também o assunto do mais recente texto atribuído a Arquíloco (Papiro de Oxirrinco 69.4708 fr. 1).

${ }^{194} \mathrm{~A}$ mesma imagem do rio Escamandro ensanguentado, precisamente com a mesma formulação, surgira já na ode 13 (v. 165). 
Baquílides

\section{8 [TítULO DESCONHECIDO]}

reputação (?)] imortal

e] glória me conceda

... e o prado...

... dourado (?)...

5 Leto (?)] isenta de dor...

... Ártemis...

alegra-te (?)] com a felicidade [e (?)

com] a muito invejável [sorte

... Delos...

$10 \quad \ldots$ por um homem (?)... 


\section{9. [Orfeu ?]}

(a)

sagradas e (?)] senhoras da dança,

filhas] de Zeus [do raio] lampejante,

donzelas (?)] de diadema de ouro,

vinde (?)], o Hélicon [abandonando ${ }^{195}$

(b)

... muito ilustre (?)...

... destinado (?)...

... de Zeus...

...

... monumento...

... dos belos ?...

... tu da vida...

... derrubou violentamente (?)...

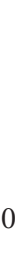


Baquílides

(c)

\section{col. I}

...com os conhecimentos (?)...

col. II

... ouro (?) ... 
(d)

... graça (?)...

... sábio (?)...

... prémio;

... e árvores...

... o brilhante encapelamento das ondas do mar tu (?), ilustre filho de Eagro ${ }^{196}$,

graças (?) às Musas de amáveis tranças;

honrou-o o subjugador archeiro,

Apolo que atinge ao longe,

ao descobrir (?)] que partilhava [dos banquetes (?)

dos deuses nascidos nas alturas

e dos homens (?)], fonte feita de mel

... persuadir...

... e a mim, imortal (?)...

... mostrar (?)...

$\ldots$ véus (?)...

... guiando [os pensamentos (?)...

... afamada pela lira (?)...

${ }^{196}$ Orfeu. 
Baquílides

... deusa e...

(e)

.. tece $(?) \ldots$

$\ldots$ cruel (?)...

(f)

.. cadáver (?)...

$5 \quad \ldots$ com coragem (?)... 
(g)

Em Pito ${ }^{197}$ brota (?)...

... glória...

... com hospitaleiros (?)...

(h)

(i)

${ }^{197}$ Possível indicação, juntamente com o anterior surgimento de Apolo, de que o ditirambo teria sido composto para execução em Delfos. 
(Página deixada propositadamente em branco) 


\section{Fragmentos}


(Página deixada propositadamente em branco) 


\section{EPINÍCIOS}

1

Para falar curto, até um espírito avisado

a ganância dos homens o domina. 
Baquílides

\section{HINOS}

\section{A. PARA APOLO, HINO DE DESPEDIDA}

apressa-te (?)...

Lóxias...

\section{B. PARA [HÉCATE]}

Hécate... [portadora de tocha ${ }^{198}$

a sagrada...

da Noite de imenso regaço a filha

tu...

\section{2}

Ai, ai, meu filho! ${ }^{199}$

Maior que qualquer lamento nos calhou um mal, [desses que se não podem pronunciar.

${ }^{198} \mathrm{Na}$ sua qualidade de deusa das sombras, Hécate era frequentemente representada segurando uma tocha.

199 Sem certezas, os críticos pensaram tratar-se de um dos filhos de Deméter, a deusa que proferiria os versos conservados. 
$3\left(^{*}\right)$ 
Baquílides

\section{PEANES $^{200}$}

\section{4 (= 22+4) [A APOLO PÍTIO, PARA ÁSINE]}

(faltam os vv. 1-20) enquanto se preparavam festins, e disse ${ }^{201}$ : «sem convite, aos fartos banquetes das gentes de bem acorrem os justos

25 homens.»...

(faltam treze ou quarenta e três linhas)

... em Pito ...

... o fim...

ordenou Febo ao filho

[de Alcmena], afamado na guerra, que [os

guiasse fora] do templo e do [centro do mundo.

Nesta terra [os fixou...

... folha (?)...

... vergando oliveiras

... Asínios

lhes chamou; mas com o tempo

${ }^{200}$ Canção coral em honra de Apolo.

201 Depois de vinte linhas iniciais perdidas, os primeiros versos referem-se à estadia de Héracles na casa de Ceíx, em Tráquis - altura em que conheceria Íole (vd. ode 16: texto introdutório e vv. 27-29). 
... de entre os Hálicos...

um adivinho de Argos ali chegou,

Melampo, o filho de Amítaon,

Epodo 2 (?)

um altar erigiu ao Pítio deus

e um santuário sagrado.

Foi essa a raíz deste [recinto (?), ${ }^{202}$

e acima da conta honrou Apolo

o divino local, onde florescem

festas e sonoras cançóes.

... ó soberano...

... e tu, [garante a felicidade

$\cdots$

E gera a Paz para os mortais riqueza $^{203}$, portadora de grande fama, e flores de cançóes de língua de mel; faz que em bem torneados altares aos deuses se queimem em loira chama coxas de bois e ovelhas de rica lá, que em exercícios gímnicos os jovens se entretenham, e com flautas e cortejos.

${ }^{202}$ Os Dríopes habitavam no Parnasso. Contra eles lutou Héracles, por razôes que não são isentas de discussão, levando-os depois para Delfos para aí os consagrar a Apolo, que lhe vaticinou que os levasse para o Peloponeso, mais propriamente para Ásine, na Argólida. Aí devia esse povo fixar-se, e cabia ao filho de Alcmena demarcar os limites do novo território com oliveiras vergadas até ao solo. Só mais tarde Melampo, um adivinho, fundaria nesse local um altar e um recinto consagrados a Apolo. $\mathrm{O}$ mito inicial tem portanto intençóes etiológicas desse local de culto.

${ }^{203}$ Mais do que dois conceitos, Paz e Riqueza são duas divindades Eirene e Pluto, respetivamente - com culto oficial um pouco por todo o mundo grego desde cedo. Recorde-se que Eirene e Ploutos são, desde logo, os títulos de duas comédias aristofânicas. 
Nas pegas de cintas de ferro dos escudos, das escuras aranhas se notam as teias,

as lanças pontiagudas e as espadas de dois gumes, destrói-as a ferrugem.

75 das brônzeas trompetes não há o estrépito, nem, com a sua doçura de mel, das pálpebras é arrebatado o sono matinal que conforta o coração. De amáveis banquetes se enchem as ruas

80 e os cantos juvenis se propagam como chamas. (faltam dez linhas)

A quedou-se... acorrem os homens justos.

B sem convite, aos fartos banquetes das gentes de bem acorrem os homens justos.

C E gera a Paz... se propagam como labaredas

\section{D}

1)

Nas esculpidas pegas de ferro dos escudos das escuras aranhas se notam as teias

2)

as lanças pontiagudas e as espadas de dois gumes destrói-as a ferrugem, 
das brônzeas trompetes não há o estrépito, nem, com a sua doçura de mel, das pálpebras é arrebatado o sono

5

um por via de outro se volve competente, no passado como hoje. [Pois não é fácil] das palavras nunca ditas as portas encontrar. $^{204}$

6

Perto que esteja o urso, não busques as suas pegadas.

${ }^{204} \mathrm{O}$ fragmento refere-se à aprendizagem do ofício poético, tendo sido interpretado (sem qualquer segurança) como uma réplica a Píndaro, poeta tradicionalmente mais de genialidade do que de trabalho. 
Baquílides

\section{DITIRAMBOS}

7

Dizem que de Lemnos]

8

Os Arcádios com as armas ao contrário

$9(*)$

$10(*)$ 


\section{PROSÓDIOS $^{205}$}

\section{$11+12$}

Um guia, um caminho leva à felicidade os mortais:

se com o espírito isento de penas alguém consegue

ao cabo levar a sua vida; ao invés, aquele

que com tratos sem fim ocupa o espírito,

e dia e noite, sem descanso, do que há de vir sempre há algo que o atormenta

o coração, esse, tem trabalho sem fruto.

pois que alívio existe

para quem, em vãs lamúrias,

sempre agita o coração?

\section{3}

Pois (?) para todos os mortais a divindade prescreveu penas, umas para uns, outras para outros.

${ }^{205}$ À letra, trata-se de cançôes para serem entoadas em cortejo ou procissáo. 
BAQuílides

\section{PARTÉNIOS $(*)$}

\section{HIPORQUEMAS ${ }^{206}$}

\section{$14+57$}

(14) Como a pedra da Lídia ${ }^{207}$

denuncia o ouro,

a excelência dos homens a sabedoria

a revela, ela e a toda poderosa

(57) Verdade, de Zeus Olímpico

concidadã, a única que dos deuses

partilha a morada...

${ }^{206}$ Tipo de composição especialmente composta para ser dançada pelo coro que a canta, o que, contudo, náo é exclusivo deste género.

${ }^{207} \mathrm{Da}$ Lídia provinha a pedra de toque com a qual se testava a qualidade do ouro. 


\section{5}

Não é tempo de repouso ou de adiamentos, antes ao templo bem cinzelado de Itónia de égide de ouro há que chegar

[e exibir uma delicada [canção

\section{A}

Protetora

16

Periclito: que tais coisas (?) desconheças não tenho eu esperança alguma ${ }^{208}$

${ }^{208}$ Nada sabemos acerca deste Periclito, apenas que se trata de um nome comum em Lesbos e na Ática. 
Baquílides

\section{POEMAS ERÓTICOS}

\section{7}

... quando ela, desde a curvatura, investe contra esses jovens, erguendo o seu alvo braço. ${ }^{209}$

18

bem jeitoso é Teócrito;

e entre os homens não és o único que o vê.

então tu, de túnica apenas, para a tua querida mulher te escapas.

... em lutas

${ }^{209}$ Baquílides parece servir-se da imagem do jogo do cótabo - famoso nos banquetes antigos, mas difícil de reconstruir -, provavelmente executado por uma prostituta diante de um grupo de simposiastas. Mas o contexto, pelos versos conservados, não é inequívoco. 
que engana [o hóspede (?)] e murmura

... [e] tece perjúrios;

e então tu, de túnica apenas,

para a tua querida mulher te escapas. 


\section{ENCÓMIOS (?) $)^{210}$}

\section{A}

... sentada

... [muito se irrita] com o pai,

e suplica-lhe, invocando (?)

a desgraçada as Maldiçóes subterrâneas, para que ele tenha a mais aguda

e terrível velhice, [já que impedia as suas bodas, mantendo-a sozinha em casa, [virgem, quando na cabeça já [se lhe volviam] brancos os cabelos.

Um filho de Ares de crista dourada, Estrofe 3 (?) assim dizem que é o pai dessa rapariga de peplo largo, Marpessa de olhos de flor em botáo, Eveno de cinta de bronze, de pulso firme e criminoso; mas o tempo por fim

${ }^{210}$ Não é seguro o género a que pertencem os próximos fragmentos, oscilando os críticos entre encómios ou escólios (cançóes de banquete). De qualquer forma, para nenhum dos anteriores temos notícia da terem constituído um livro autónomo na grande edição a que pertenceria o Papiro de Londres. 
o dominou, como a forte necessidade

Estrofe 4 (?)

de vingança], contra a sua vontade.

... do sol (?)

por própria iniciativa se aproximou], montando

os cavalos de rápido galope] de Poséidon,

Idas,] o afortunado filho [de Afareu.

Com o seu consentimento], o herói raptou

a rapariga [de encantadora cabeleira;

do santuário (?)]da deusa de formoso véu ${ }^{211}$

a levou (?)] ...

... veloz mensageiro

... quando chegou

Estrofe 6(?)

(faltam os vv. 32-35)

Estrofe 7 (?)

Ao pai a desvairada [raiva?] ... , do mais alto ${ }^{212}$ Estrofe 8 (?)

${ }^{211}$ Pode tratar-se do santuário de Artémis onde, segundo um escólio à Ilíada 9.557, Marpessa dançava quando Idas a raptou.

${ }^{212}$ Devemos estar no momento em que, despeitado, Eveno se lança ao rio Licormas. 
Baquílides

de...

45 filha...

Marpessa...

louro (?)...

... e...

Estrofe 9 (?)

50

55

Estrofe 10 (?)

.. graça (?)... 


\section{B [A AleXandre, Filho de Amintas] ${ }^{213}$}

Não mais, bárbiton ${ }^{214}$, suspenso de uma cavilha, Estrofe 1 a clara voz das tuas sete cordas voltes a silenciar! Vem cá, para as minhas mãos! Quero enviar algo a Alexandre, uma pena dourada das Musas ${ }^{215}$

e um adorno para os festins dos vintes do mês ${ }^{216}$, Estrofe 25 quando a doce necessidade das taças que se agitam o delicado coração dos jovens acalenta e a esperança em Cípris lhes entorpece o espírito,

embebida que esteja nos dons de Diónisos: Estrofe 3 ele nos homens lança ao vento os cuidados; as ameias das cidades se apressa a destruir

${ }^{213}$ Alexandre da Macedónia, filho do rei Amintas I, terá sucedido ao pai por volta de 495 a.C. e governado sobre a Macedónia durante mais de quarenta anos, até à sua morte, fixada em 452 a.C. Por este lapso de tempo, e pelo facto de o poema ser considerado obra da juventude de Baquílides, tem-se aceitado o ano de 490 a.C. como sua datação relativa.

${ }^{214}$ Diferente de uma lira, trata-se de um instrumento de sete cordas, mais longo e escuro do que o primeiro. Píndaro atribuiu a sua invenção a Terpandro; já Ateneu, considerou-o criação de Safo ou Anacreonte, informaçáo cuja validade não podemos confirmar, mas que parece remeter para a tradição iconográfica desses dois líricos arcaicos. No mais conhecido dos vasos, da autoria do pintor de Brigos, que atesta a forma deste instrumento - Munique n. ${ }^{\circ} 2416$ (J753) -, Safo e Alceu surgem ambos a tocá-lo.

${ }^{215}$ Imagem do próprio poema, que realça também a sua mobilidade e sugere o envio para Alexandre.

${ }^{216}$ Segundo uma tradição antiga, seria por essa altura do mês que teriam lugar os maiores festins privados. 
e de todos os mortais se julga soberano.

Em ouro e marfim brilham as casas Estrofe 4 e fartas de trigo, pelo mar refulgente,

15 as naus trazem do Egito riqueza imensa; assim se agita o coração de quem bebe.

Ó [glorioso] filho [de Amintas de alto porte Estrofe 5

... para os homens, afinal, que [melhor

20 proveito] do que ao coração dar [alegria?

Estrofe 6

... escuridão. A prosperi[dade plena não a consegue homem [algum durante o vasto tempo

25 da sua vida.] E o que alcançou semelhante... Estrofe 7

... os fundamentos (?)...

... em tempos...

... muito divino (?)...

Estrofe 8

30

... semideuses...

... quando...

... com o vinho (?)...

$35 \quad$... pois que...?

(faltam os vv. 36-46) 
Estrofe 11 (?)

Estrofe 12 (?) (47?)

portador de grinaldas (?)...

por isso de jovens de igual...

e a Febo, o da bela lira 


\section{C A Hierão de Siracusa ${ }^{217}$}

Não permitas [que descanse] ainda

Estrofe 1

o bárbiton de claro som! Quero [uma nova

e de muitas notas flor das Musas a Hierão

e] aos seus louros cavalos agora [enviar,

- encantadora será, quando terminada -

e aos varóes que com ele se banqueteiam,

para o Etna, bem construída cidade, se também Estrofe 2 no passado o celebrei, [quando em Cirra obteve Ferenico, com as suas patas velozes,

a vitória junto do Alfeu,

um homem enchendo de alegria

... para mim (?) então as raparigas...

Estrofe 3

e os rapazes], quantos [o altar] todo em ouro de Zeus

em pleno refulgir com seus cortejos] deixaram

qualquer que] dos que habitam sobre a terra

... não com um covarde...

As habilidades], por certo, são todas

Estrofe 4

${ }^{217}$ A menção da cidade do Etna (v. 7), fundada por Hierão em 475 a.C., bem como a referencia à vitória olímpica de Ferenico, no ano anterior (vv. 7-10), levaram os estudiosos a datar o poema de 475 a.C. ou pouco depois. 
inumeráveis; mas, confiante no deus, [declaro: nenhum outro] homem [contempla

a Aurora de brancos corcéis, nenhum que seja tão brilhante, quando sobre os mortais derrama a luz (faltam vv. 25-27?)

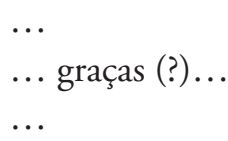

Estrofe 5

... enviado pelos deuses cantava...

Estrofe 6

... e a natureza (?)...

... cabeleira...

Estrofe 7

... rico em ouro...

\section{D}

(col. I)

Lá do alto (?) a formosa esposa [de Páris (?) (col. II) para o derradeiro [caminho] se lançou [, Enone (?) ${ }^{218}$;

${ }^{218}$ Além de Enone, pode o poeta estar a referir-se a Altaia, mãe de 
nem a infeliz Níobe [tanto sofreu (?), ela que os [augustos] filhos de Leto destruíram, com os seus [dez] filhos e filhas, com flechas de longa ponta. Ao vê-la, o pai] de elevado trono, Zeus, desde o céu dela se compadeceu, [perturbada] por afliçóes sem remédio, e então a converteu em escarpada rocha, pondo fim ao seu intolerável [sofrimento (?) $)^{219}$

e nem...

(faltam dois versos?)

... «venero...» (?)

(faltam pelo menos 13 versos)

Meleagro e esposa de Eneu. O contexto e as circunstâncias da composiçáo são muito obscuros, fazendo no entanto sentido que se trate de um conjunto de exemplos míticos apresentados com intençóes consolatórias.

${ }^{219}$ Níobe, filha de Tântalo, teve de Anfíon um grande número de filhos (as fontes variam quanto à sua contagem), o que a fez, por orgulho, proclamar-se superior a Leto, máe de apenas dois, Apolo e Ártemis. Como castigo, os filhos de Leto mataram os filhos de Níobe, e ela, em dor extrema, subiu ao monte Sípilo, onde consta que os deuses a transformaram em rocha. 


\section{$20 \mathrm{E}$}

... de bronze (?)...

... negro (?)...

... destino...

... que tudo dá, imortal (?)...

... granjeou...

[o deus] supremo de poderoso trovão [o Sono

[e a Morte] desde o Olimpo [coberto de neve]

[envia] ao [destemido lutador],

Sarpédon ${ }^{220}$, [soberano da Lícia] rica em trigo.

[E o que opera de longe], o de tranças douradas ${ }^{221}$, [este] discurso [proferiu]...

... homens...

... imortal...

... o fim;

ao (?) Simoente ${ }^{222}$ que sempre corre [caiu], derrubado] pelo [implacável] bronze.

... tempo...

... mente justa...

... ânimo...

${ }^{220}$ Sarpédon transformou-se em símbolo da felicidade após a morte. Chefe dos Lícios e aliado dos Troianos, morreu em combate às mãos de Pátroclo e foi, já morto, levado pelo Sono e pela Morte para a Lícia, sua terra natal.

${ }^{221}$ Apolo.

${ }^{222}$ Rio de Tróia. 
BAQuílides

... diferentes...

\section{F}

não (?)...

nem (?)...

5

delicioso (?)...

\section{G}

branca (?)...

5 e por amor (?)...

a qual...

21

De bois não temos os corpos, ouro 
ou carpetes da cor da púrpura, apenas um espírito bem-humorado, uma Musa glicodoce e, em taças

da Beócia, um vinho bem docinho. 223

$\left.22{ }^{*}\right)$

${ }^{223}$ Pode o poema ter sido composto para uma festa pública ou privada, estando em causa, de qualquer modo, a celebração dos Dioscuros, Castor e Pólux, os irmãos de Helena. 


\section{FRAGMENTOS DE GÉNERO INCERTO}

23

estão livres do jugo das cruéis

doenças], imperturbáveis,

em nada semelhantes aos homens ${ }^{224}$.

\section{4}

Aos mortais não é dado escolher livremente nem a prosperidade, nem o inflexível Ares, nem a guerra civil que tudo destrói, antes dirige uma nuvem, a uma e a outra terra, o Destino que tudo concede.

$34+25$

(34) as disposições dos homens são distintas, aos milhares.

(25) a poucos mortais concedeu a divindade sempre agir no momento oportuno, e a velhice encanecida atingir sem antes encontrar a miséria.

${ }^{224} \mathrm{O}$ texto, que pode estar corrupto, poderia aludir aos Hiperbóreos (vd. supra, ode 3.59 e nota 31 ) ou aos homens da idade heroica. 
$26(*)$

27

extenso é o caminho

$28\left(^{*}\right)$

29

1)

a sombra tingida de negro do varão de Ítaca ${ }^{225}$

2)

a sombra oculta na escuridão do varão de Ítaca

225 Normamente associado a Ulisses, o "varão de Ítaca» pode também ser Elpenor, cuja sombra surge num vaso ático de c. 440 a.C. ao lado do primeiro herói. 
Baquílides

30

essa Mênfis livre de tempestades

e o Nilo abundante em canas $^{226}$

$\left.31{ }^{*}\right)$

$32\left(^{*}\right)$

33

... o ouro puro denuncia ao juízo dos mortais ${ }^{227}$

$34\left(^{*}\right)$

35

... à corrente do mar tendo escapado

${ }^{226} \mathrm{~F}$. Blass propôs, sem grande aceitação por parte dos demais editores, incluir este verso algures numa estrofe ou antístrofe perdida da ode 13 .

${ }^{227}$ Cf. a mesma ideia no fr. 14. 
$36\left(^{*}\right)$

37, 37A, 37B $\left(^{*}\right)$

$38\left(^{*}\right)$

39

de cornos semelhantes a torres

$40\left(^{*}\right)$

$41\left(^{*}\right)$

$42(*)$ 
$43\left(^{*}\right)$

$$
44\left(^{*}\right)+66
$$

(66) $\quad$... no espírito (?)...

... com violência (?)...

... levar a mal (?)...

...

nem se aproximou ${ }^{228}$ (?)...

e assim falou ${ }^{229}:$ (?)...

«aflige-me o espírito...

sem convite [ele veio (?)]

para o agradável [festim,

10 o Centauro que nas montanhas se deita,

e reclamou a minha filha...

desejando levá-la como esposa

para Maleia; quanto a mim...

à minha recusa, [ameaça-me] mais

\section{[violentamente}

dizendo (?): «agiste (?) muito sem razão;

eu, porém... tu (?)...

${ }^{228}$ Possivelmente Héracles.

229 Dexâmeno. Rei da cidade de Oleno, na Acaia, junto de quem se refugiou Héracles depois de expulso por Augias. Ao herói prometeu a mão da filha, Mnesímaca, antes de ele partir para uma expedição. No regresso, encontrou a jovem prometida, à força, ao centauro Eurítion, ao qual acabou por matar de forma a tomar para si a rapariga. Algumas fontes confundem esta lenda com essa outra de Héracles, Dejanira e o centauro Nesso, também tratada por Baquílides (vd. ode 16 e respetivo texto introdutório). 
oxalá... inocente (?)...

calhar estar liberto (?)

$45\left(^{*}\right)$

$46\left(^{*}\right)$

$47\left(^{*}\right)$

$48\left(^{*}\right)$

$\left.49{ }^{*}\right)$

$\left.50{ }^{*}\right)$

$51\left(^{*}\right)$ 
Baquílides

$52\left(^{*}\right)$

$53\left(^{*}\right)$ 


\section{FragmeNTOS DE ATRIBUIÇÃo DUVIDOSA}

$53 \mathrm{~A}$

essa grinalda inflamada

com botôes de rosa

\section{4}

próspero, nenhum dos mortais o é por toda a vida.

\section{5}

em verdade, não estão à disposição os muito disputados dons das Musas, para que os leve quem os encontrar.

56

a excelência, se elogiada, cresce como uma árvore.

$57\left({ }^{*}\right)$ 
BAQUílides

$58(*)$

$59\left({ }^{*}\right)$

$60^{230}$

5

... corpo

Por causa da nossa

juventude (?)] os carros (?)

dos inimigos retivemos (?),

10

sob inumeráveis e incessantes

sofrimentos sentadas;

pois [na] gélida guerra

${ }^{230}$ A ser aceite a atribuição dos fragmentos 60 e 61 a Baquílides, provenientes do mesmo papiro, eles seriam parte de dois ditirambos, desde logo pelo título do fragmento 61. Quanto ao fragmento 60, títulos como Os filhos de Laomedonte, Cabiros ou Castor e Pólux - ou mesmo que integrasse o ditirambo Cassandra (ode 23) - foram já avançados, embora o texto preservado seja insuficiente para qualquer leitura segura. 
alcançaram...

... ao pai (?)...

... para eles...

... da liberdade de belas flores

para o Aqueronte... que ignora os deuses

bem-amados...

e do Hades...

muito... esse discurso;

Epodo (?)

quando o madeiro pelos promontórios

ensombrados e fartos de arvoredo

uma vaga [transportou] desde Ílion,

algum dos deuses

abertamente [disse (?)

que um devia ficar ali...

e outro... à funesta

morte fugir.

Sucessivos gritos (?)

ao céu chegaram, [de mulheres (?)

graças a inesperada alegria...

nem dos homens

nos bancos... a boca

ficou por ouvir;

e as raparigas suplicavam...

iê, iê!! 


\section{As FILHAS DE LEUCIPO ${ }^{231}$ \\ Para a de olhar violáceo preparando, para Cípris, um formoso coro de novas cançóes.}

\section{2}

(a) $\quad .$. de mortais

... aos que vão...

... o que muito sofreu ${ }^{232}$ estava...

... de bronze

... aproximando-se...

... negras (?)

... valor.

Cada homem...

da pátria, as quais, para eles (?)...

... de grande fama...

$\cdots$

... terrivelmente

... toda...

... o que tem (?)...

${ }^{231}$ Pelas filhas de Leucipo lutaram Castor e Pólux contra os filhos de Afareu, Idas e Linceu, terminando por morrer os dois últimos e Castor. Sabemos da existência de um santuário em Esparta onde recebiam culto.

${ }^{232} \mathrm{O}$ epíteto do original surge, na literatura grega, aplicado a Héracles e Édipo, mas o estado do texto não permite identificar o protagonista e o contexto em causa. De notar ainda que um epíteto semelhante é, na ode 5 (v. 157) aplicado a Meleagro. 
... ao homem, na verdade, nem (?)...

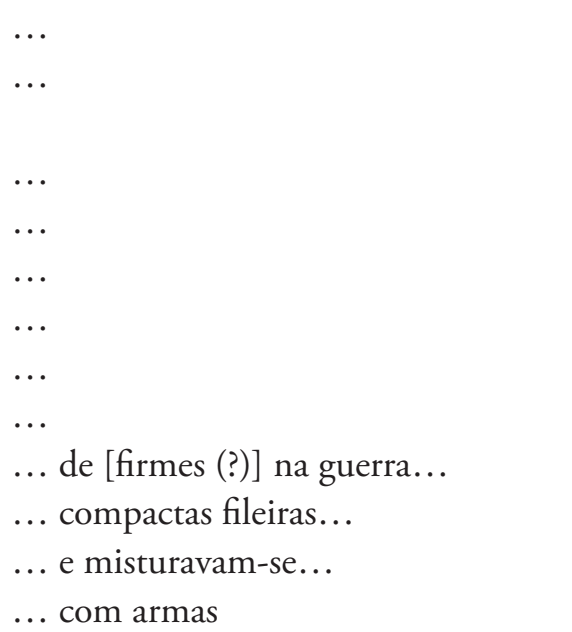

63

das Piérides o servidor ${ }^{233} \ldots$

de Mnemósine ${ }^{234}($ ?)] de vigoroso pai

... doce (?)...

... domador de cavalos (?)...

... leis (?) ... Olimpo (?)...

${ }^{234}$ Filha de Urano e mãe das Musas. 
... das costas do mar (?)...

... às marítimas...

deusas de tranças...

10

... matou com o arco (?)...

$64^{235}$

5

... o filho (de) Alcmena...

e conduz desde [Cálidon...

... e daí...

transportando (?)...

10

a inexperiente e de braços róseos...

... com as mãos...

... através do rio...

como cavalos que seguram...

mas quando, finalmente...

a loucura (?) de Afrodite...

o Centauro se lançou [sobre a rapariga (?)

e então gritou [Dejanira (?),

ao amado esposo [suplicando (?)

que se apressasse...

20 da mulher...

235 O fragmento, que Bowra atribuiu a Píndaro (fr. 341), narra os antecedentes míticos da ode 16 - a tentativa de rapto de Dejanira pelo centauro Nesso (vd. ode 16.31-35 e texto introdutório). Particularmente interessante é a referência à clava como arma utilizada por Héracles (v. 26), ao invés do arco e da flecha, a versão mais comum. 
olhar flamejante...

morte e...

impronunciável. Não...

no combate...

e na mão direita (?)

uma grande clava, [atingiu (?)

a fera selvagem [na cabeça (?)

no meio da orelha...

e esmagou...

dos seus olhos...

e das sobrancelhas;...

com os pés (?), destemido (?)... 


\section{EPIGRAMAS ${ }^{236}$}

Filha muito reputada de Palante ${ }^{237}$, soberana Vitória, com benevolência o delicioso coro dos [Craneus (?) ${ }^{238}$ oxalá sempre contemples, e nos folguedos das Musas muitas grinaldas deponhas sobre Baquílides [de Ceos (?).

Eudemo este altar em seu campo dedicou ao mais fértil de quantos ventos há, Zéfiro; pois, invocado, veio propício para que logo pudesse debulhar o grão das maduras espigas.

${ }^{236}$ Ambos os epigramas devem datar do período helenístico.

${ }^{237}$ Um dos Titãs.

${ }^{238} \mathrm{Ou}$ dos «habitantes de Carteia» (uma cidade da ilha de Ceos). 
ApÊNDICES 
(Página deixada propositadamente em branco) 


\section{ApÊNDICE 1}

\section{Fragmentos de Epinícios e Ditirambos}

21: Escólio a Píndaro, Olimpicas 10.83 a

22: Papiro de Oxirrinco 23.2368

23: Papiro de Oxirrinco 23.2368

24: Papiro de Oxirrinco 23.2364; Papiros de Berlim $16139+21209$

25: Papiro Ashmoliano 20

26: Papiro de Oxirrinco 23.2364

27: Papiro de Oxirrinco $23.2364+20.661$

28: Papiro de Oxirrinco 2365, fr. 1 (1-10)

29: Papiro de Oxirrinco 32, add. ao P. 2364

\section{Fragmentos}

1: Dos Epinícios de Baquílides (Estobeu 3.10.14)

1A: Papiro de Oxirrinco 23.2366

1B: Baquilides diz que ela é filha da Noite: "Hécate portadora de tocha, filha da Noite de imenso regaço» (Escólio a Apolónio de Rodes 4.467)

2: Dos Hinos de Baquilides (Estobeu 4.54.1)

3: A Celeu ${ }^{1}$, menciona-o Baquílides nos Hinos (Escólio a Arostófanes, Acarnenses 47)

${ }^{1} \mathrm{O}$ primeiro rei de Elêusis, que acolheu Deméter quando esta errava pela terra em busca da filha. Em agradecimento, ter-lhe-á a deusa ensinado os Mistérios de Elêusis. 
4: A: Baquilides, contando como Héracles chegou a casa de Céix, afirma: [segue-se o fragmento] (Ateneu 178b) B: (Zenóbio 2.19) C: Dos Peanes de Baquilides: [seguese o fragmento] (Estobeu 4.14.3) D: De modo que mesmo as hipérboles poéticas se revelam insuficientes para descrever a situaçấo de então: [segue-se o fragmento 1)], e [fragmento 2)] (Plutarco, Numa 20.6)

5: Clemente de Alexandria 5.68.5

6: Aos caçadores covardes se aplica este provérbio. Recorda-o Baquilides nos Peanes. (Zenóbio 2.46)

7: Com esta história também Baquílides concorda nos seus Ditirambos, que os Helenos trouxeram de Lemnos Filoctetes por causa de um vaticinio de Heleno. É que estava destinado que, sem o arco de Héracles, Tróia não seria destruida. (Escólio a Píndaro, Piticas 1.100)

8: De acordo com o costume dos que estâo de luto, mantendo em direção ao solo a ponta da lança, não o cabo, já que os nossos antepassados, num funeral, faziam tudo ao contrário do que era hábito, e invertiam mesmo os seus escudos por causa das divindades que neles estavam gravadas, não fossem as suas imagens poluir-se com a visäo do cadáver; assim se mantiveram os Arcádios, como diz Baquílides nos Ditirambos. (Sérvio, Comm. a Virgílio, Eneida 11.93)

9: $\left[\mathrm{LAOCOONTE]^{2 }}\right.$ Por certo Baquilides refere-se a Laocoonte è à sua esposa, bem como às serpentes que vieram das ilhas Calidnas e se converteram em homens. (Sérvio, Comm. a Virgílio, Eneida 2.201)

10: [EUROPA] Zeus, ao contemplar Europa num prado, a filha de Fénice, enquanto apanhava flores com as Ninfas,

${ }^{2}$ Laocoonte era um sacerdote de Tróia que, tendo-se unido sexualmente com a mulher diante da estátua de Apolo, recebeu desse deus o castigo de ver ambos os filhos assassinados por serpentes gigantescas. 
apaixonou-se por ela, desceu do Olimpo e transformou-se num touro que exalava açafrão da boca. Assim enganando Europa, carregou-a sobre o dorso e atravessou o mar rumo a Creta, onde se uniu a ela. Nesse estado, em seguida, deu-a em casamento a Astérion, rei dos Cretenses. Tendo ela ficado grávida, deu à luz três filhos, Minos, Sarpédon e Radamante. Esta história está em Hesiodo (fr. $140 \mathrm{M}-\mathrm{W}$ ) e em Baquilides. ${ }^{3}$ (Escólio D $=\mathrm{A}+\mathrm{B}$ Ilíada 11.292)

11+12: Dos Prosódios de Baquílides (Estobeu 3.1.12, 4.44.16, 46; Apostólio 6.55 sqq.)

13: Dos Prosódios de Baquílides (Estobeu 4.34.24)

\section{Parténios $^{4}$}

Não desconhece [Platão] o facto de muitos parténios dóricos terem sido compostos por Álcman, Pindaro, Simónides e Baquílides. (Pseudo-Plutarco, Sobre a Música 17)

14+57: Dos Hiporquemas de Baquílides (Estobeu 3.11.19-20)

15: Dionísio de Halicarnasso, Acerca da Composição Literária 25.206

15A: onde reinou Itono, filho de Héracles; trata-se de uma cidade da Beócia. E por isso Baquílides chamou Itónia a Minerva e qualificou-a de Protetora. Este Baquilides é o poeta grego ao qual Horácio imitou naquela ode em que Proteu ${ }^{5}$ narra

${ }^{3}$ Alguns estudiosos consideraram que o escoliasta se referia aos versos 29 sqq. da ode 17 - onde se refere Europa como mãe de Minos -, embora outros considerem que Baquílides dedicou todo um poema a essa figura.

${ }^{4}$ Hino de execução processional, mas cantado exclusivamente por um coro de raparigas. $\mathrm{O}$ principal cultor deste género, de quem conservamos o mais extenso fragmento - por isso designado Grande Partheneion (fr. 1) - foi Álcman, poeta coral do século VII a.C.

${ }^{5}$ Erro por Nereu. 
a destruição futura de Tróia. (Lactâncio, Comm. a Estácio, Tebaida 7.330)

16: Fique claro que mesmo poemas inteiros sáo compostos em créticos, como em Baquílides: [segue-se o fragmento] (Heféstion, Manual de Métrica 14.7)

17: Chamavam ao lançamento do cótabo «desde a curvatura", porque o braço direito se curvava quando o faziam. Mas outros afirmam que a "curvatura» é uma espécie de taça. Baquilides, nos Poemas Eróticos: [segue-se o fragmento] (Ateneu 782d-e)

18: Alguns [refróes] há que se designam de epiftegmáticos, distintos dos efimnios na medida em que uns contribuem com algo para o sentido, ao passo que os outros são um acrescento supérfluo à estrofe, no que ao conteúdo diz respeito; por exemplo, em Baquilides: (Heféstion, Sobre os Poemas 7.3)

19: Papiro de Oxirrinco 23.2361. E uma vez mais no mesmo Baquílides: "então tu, de túnica apenas, para a tua querida mulher te escapas.» (Heféstion, Sobre os Poemas 7.3)

20B: Papiro de Oxirrinco 11.1361. É que não é de qualquer estado de alegria e proveito que surge o divertimento, o gozo e o contar de piadas, senão apenas desse que aliena $o$ entendimento e o inclina para o engano, como ocorre por efeito da embriaguez. E por isso Baquílides afirma: "a doce necessidade... o coração de quem bebe.» (Ateneu 39e)

20C: Papiro de Oxirrinco 11.1361

20D: Com efeito, Homero diz que os seus [de Niobe] filhos e filhas foram duas vezes seis, Euripides duas vezes sete, Safo duas vezes nove, Baquilides e Pindaro duas vezes dez, ao passo que outros escritores consideraram que foram apenas três. (Aulo Gélio, Noites Áticas 20.7)

20E: Papiro de Oxirrinco 23.2362

20F: Papiro de Oxirrinco 23.2362 
20G: Papiro de Oxirrinco 23.2362

21: Também Baquílides alude às taças da Beócia nos versos seguintes, nos quais se dirige aos Dioscuros, convidando-os para um festim: [segue-se o fragmento] (Ateneu 500a)

22 = fr. 4. 21-25.

23: Ouçamos pois, uma vez mais, o poeta lírico Baquilides, quando fala acerca da divindade: [segue-se o fragmento] (Clemente de Alexandria, Stromateis 5.110.1; Eusébio de Cesareia, Preparação Evangélica 13.679)

24: De Baquilides: [segue-se o fragmento] (Clemente de Alexandria, Stromateis 6.14.3)

34+25: "Com dupla bilis»: em desacordo... "Opinióes de dupla bilis»: de "dupla»; ou "de dúplice caráter», pelo recurso da metalepse ou mudança. Pois "bilis» é o temperamento e "temperamento" é o caráter. Baquílides: [segue-se o fragmento 34] (Hesíquio, s.v. dícholoi; Zenóbio 2.325); E Baquílides disse: [segue-se o fragmento 25] (Clemente de Alexandria, Stromateis 6.14.3)

$$
26=5.23-24
$$

27: De acordo com Baquilides: [segue-se o fragmento] (Plutarco, Numa 4.11)

$$
28=1.13-14 .
$$

29: "Eidolon»: a imagem da sombra; ou a representação do corpo, uma sombra enevoada; assim também em Baquilides: [segue-se o fragmento 1)] (Suda, s.v. Eidolon; Escólio B a Ilíada 5.449; Apostólio 3.37); [fragmento 2)](Et. Magn. 296.1; Et. Gen. S.v. eidolon; Léxico de Cirilo, cit. Cramer, Anecdota Parisiensia 4.168.30; Lexicon Sannaiticum 14.21).

30: Mênfis... a mais antiga e régia das cidades, acerca da qual diz Baquílides: [segue-se o fragmento] $E$ que do termo "cana", usado em sentido próprio, se diz "rio canoso", 
de um modo geral, deixá-lo-á claro Homero no que se segue. Igualmente se poderia dizer "abundante em canas", de acordo com Baquílides, que chama "abundante em canas" ao Nilo. (Eustácio, Comm. a Homero 864.22)

$$
\begin{aligned}
& 3 \mathbf{1}=\text { fr. } 1 \mathrm{~B} . \\
& \mathbf{3 2}=18.2 .
\end{aligned}
$$

33: De forma semelhante Baquilides: [segue-se o fragmento]. Este iambo tem também, no final, um tribraco. (Prisciano, Acerca dos metros de Terêncio = Keil, Grammatici Latini 3.428.21)

\section{4: vd. fr. 25}

35: No entanto, se se trata de um nome, é coerente o acento proparoxitono, por causa do acusativo em Baquilides; por exemplo: [segue-se o fragmento] (Et. Magn. 676.25, s.v. plemmyris; Et. Gen. B)

$$
36=13.208 \text {. }
$$

37, 37A, 37B = fr. 54, 55, 56.

38: Assim, para reforçar com mais firmeza esta linha de conduta [o Imperador Juliano] sempre estava a servir-se de um dizer do lírico Baquilides, que dizia ler com prazer, e de quem [dizia] que, qual pintor requintado que pinta um belo rosto, assim a moderação adorna a vida de quem aspira à grandeza. (Amiano Marcelino 25.4.3)

39: De maneira que também nos nomes se produzem metaplasmos, como [segue-se o fragmento] em Baquilides. (Apolónio Díscolo, Acerca dos Advérbios 183.15)

40: ... a menos que a Cária fosse também chamada Fenícia, como se encontra em Corina e Baquilides. (Ateneu 174f)

41: "E a Realeza te dou por esposa»: personifica a Realeza como se fosse uma mulher. Eufrónio diz que a Realeza é filha de Zeus e parece administrar as coisas relativas à imortalidade, o 
que em Baquílides cabe a Atena, que tinha a intenção de dar a imortalidade a Tideu. (Escólio a Aristófanes, Aves 1536)

42: Baquilides diz que Reia curou Pélops mergulhando-o de novo no caldeiräo. ${ }^{6}$ (Escólio a Píndaro, Olimpicas 1.40a)

43: Tanto em Simónides como em Baquilides a cidade [Iúlis] é mencionada. (Himério, Discursos 27.30)

44+66: 44: Baquilides acredita num Eurition diferente; na verdade, diz que quando ele era hóspede de Dexâmeno na Elide, cheio de insolência atentou contra a filha do individuo que lhe havia dado hospitalidade e que, por essa razão, foi morto por Héracles que, oportunamente, estava por essa casa. (Escólio a Odisseia 221.295; cf. Eustácio, Comm. a Homero 1909.61). 66: Papiro de Oxirrinco 23.2395

45: Alguns estabelecem a genealogia de vários Aristeus, como é o caso de Baquilides: um filho de Caristo, outro de Quiron, outro da Terra e do Céu, um último filho de Cirene. ${ }^{7}$ (Escólio a Apolónio de Rodes 2.498)

46: fr. 20D. 4 sqq.

47: Alguns dizem que Perséfone foi raptada da Sicilia, mas Baquilides diz que foi de Creta... ${ }^{8}$ (Escólio a Hesíodo, Teogonia 914)

48: De acordo com Baquílides e Aristóteles, o filósofo, [Homero] era de Ios. (Vida de Homero 5.5)

49: O Caíco não corre desde o Ida, como disse Baquílides... (Estrabão 13.1.70)

${ }^{6}$ Tântalo matou o filho Pélops, despedaçou-o e, uma vez cozinhado, serviu-o aos deuses olímpicos. Estes, percebendo a trama, recusaram comê-lo, à exceção de Deméter, que lhe comeu um ombro. Pélops terá depois sido ressuscitado (por Reia, segundo Baquílides, por Cloto, uma das Moiras, ou por Hermes, dependendo das versões) e substituído o seu ombro por um pedaço de marfim.

${ }^{7}$ Aristeu era uma divindade rural que recebia culto em Ceos.

${ }^{8} \mathrm{O}$ facto de, na ode 3 (v. 2), a deusa vir associada à Sicília, levou à associaçáo destes testemunhos com outro poema, para nós perdido. 
50: $O$ Ríndaco é um rio da Frígia referido por Baquilides. (Escólio a Apolónio de Rodes 1.1165a)

51:Também mencionam [o oricalco ${ }^{9}$ ] Estesicoro $e$ Baquílides... (Escólio a Apolónio de Rodes 4.973)

\section{2}

Do sangue que jorra das suas partes intimas nasceram na Terra três Erínias: primeiro Tisifone, Megera e Alecto com estas, e com elas os quatro Telquines, como são chamados, Acteu, Megalésio, Ormeno e Lico, que Baquilides diz serem filhos de Némesis e Tártaro, mas outros afirmam que o são da Terra e do Mar. (Tzetzes, Teogonia 80 sqq.)

53: $E$ de acreditar que ela, sozinha, tenha engendrado dezanove filhos, e não cinquenta, como escreve Baquilides acerca dos filhos de Téano. (Escólio a Ilíada 24.496) (cf. 15)

\section{Fragmentos de atribuiçáo duvidosa}

53A: Meu caro, é justo que ponhas de lado, como fizemos nós, [segue-se o fragmento] ou que nos digas, como costumas fazer em qualquer circunstância, em que medida as grinaldas de flores nos ajudam a beber. (Plutarco, Questóes de Banquete 3.1.2)

54: No mesmo [Baquílides]: "para os mortais, não nascer é o melhor, I nem do sol jamais contemplar a luz» (5.160), e

${ }^{9} \mathrm{Um}$ metal precioso mas de entendimento obscuro, ao que parece relacionado com o cobre. 
[segue-se o fragmento] (Estobeu 4.34.26)

55: Clemente de Alexandria, Stromateis 5.16.8

56: Aqueles que, por si mesmos, se entregam à fé, como quantos aprendem sozinhos e por vontade própria, engrandecemse com o elogio: [segue-se o fragmento] (Clemente de Alexandria, Pedagogo 1.94.1)

57: vd. fr. 14.

58: Baquílides e Pindaro, quando cantaram os elogios de Hierão e Gélon na equitação, sugeriram que foram os Siciliotas a inventar a equitaçâo. (Escólios BD a Élio Aristides, Panatenaico 3.317) Erecteu foi o primeiro a receber de Atena o carro; outros afirmam que Pélops o recebeu de Poséidon; e outros dizem que veio da Sicilia, já que Pindaro e Baquilides, quando celebraram Hierão e Gélon (...) e admiraram muito a sua condução de carros, para lhes agradar disseram que foram os Siciliotas quem primeiro inventou o carro. (Escólio C a Élio Aristides, Panatenaico 3.317)

59: Diz-se que Polifemo não só amou Galateia como também dela teve um filho, de nome Gálato, como testemunhou Baquilides. (Natalis Comes, Mitologia 9.8)

60: Papiro da Sociedade Italiana 10.1181

61: Papiro da Sociedade Italiana 10.1181

62: Papiro de Oxirrinco 6.860

63: Papiro de Oxirrinco 4.673

64: Papiro de Berlim 16140

\section{EPIGRAMAS}

1: De Baquílides: [segue-se o fragmento] (Antologia Grega 6.313)

2: De Baquilides. Oferenda ao vento Zéfiro do lavrador Eudemo: [segue-se o fragmento] (Antologia Grega 6.53) 
(Página deixada propositadamente em branco) 


\section{APÊNDICE 2: \\ Testemunhos ANTigos \\ SOBRE A VIDA E A OBRA DE BAQUÍLIDES}

\section{1}

Baquílides, o Ceio, da ilha de Ceos, e da cidade de Iúlis (pois tem, com efeito, quatro cidades: Iúlis, Carteia, Corésia e Poiessia), filho de Médon [ou de Mídon], este último filho do atleta Baquílides; parente do poeta lírico Simónides, e ele próprio um poeta lírico.

(Suda, s.v. Bakchylides)

\section{2a}

Ceos chegou a incluir quatro cidades, mas restam apenas duas, lúlis e Carteia, às quais foram anexadas as restantes, Poiessia a Carteia e Corésia a Iúlis. De Iúlis era Simónides, o poeta mélico, e Baquílides, seu sobrinho.

(Estrabão 10.5.6)

\section{2b}

Iúlis: cidade da ilha de Ceos, a partir da fonte Iúlis. Dela é Simónides, o poeta mélico, e Baquílides, seu sobrinho. (Estêvão de Bizâncio, s.v. Ioulis)

\section{2c}

Dizem que Hierão, o tirano da Sicília, no início era uma pessoa comum e o mais desinteressado pelas artes de entre os homens, e que no que toca a rusticidade pouco se distanciava do irmão Gélon. Mas que, quando sobre ele se 
abateu a doença, então se tornou o maior amante das artes de entre os homens, já que empregava o repouso que lhe vinha da sua debilidade em audiçôes instruídas. Ora, uma vez restabelecido, Hierão privou com Simónides de Ceos, Píndaro de Tebas e Baquílides de Iúlis. Quando a Gélon, era um indivíduo desinteressado pela arte.

(Eliano, Varia Historia 4.15)

\section{3}

Mídilo: é esse o nome do pai de Baquílides; Mídilo deriva de meidiô (sorrir), como de pheido (economia), de onde vem pheidomai (economizar), deriva Fídilo.

(Etymologicum Genuinum s.v. Meidylos; cf. Etymologicum Magnum 582.20)

$4 a$

Baquílides e Diágoras, o ateu, são muitas vezes elogiados em conversas.

(Eusébio, Crónica, Olimpíada 78.2 = 467 a.C.)

4b

Crates, o cómico, Telesila e ainda Baquílides são considerados ilustres.

(Eusébio, Crónica, Olimpíada 82.2 = 451 a.C.)

$4 c$

Baquílides estava na sua maturidade.

(Chronicon Paschale 162b [304.6] = Olimpíada 74.4 $=480$ a.C.)

4d

Baquílides estava na sua maturidade.

(Sincelo 257c [489.7] = Olimpíada $88=428$ a.C.) 
$4 e$

Baquílides, o escritor de poemas, é conhecido.

(Eusébio, Crónica, Olimpíada 87.2 = 431 a.C.)

\section{$5 a$}

(Píndaro,) dizem, também ouviu Simónides, já que era mais novo do que ele, mas mais velho do que Baquílides. (Eustácio, Proémio do Comm. a Pindaro $25=$ III.297.13 Drachmann)

\section{$5 b$}

(Píndaro) era mais jovem do que Simónides, mas mais velho do que Baquílides.

(Tomás Magistro, Vida de Pindaro I.5.4 Drachmann)

\section{5c}

Diágoras, filho de Teleclides ou Teleclido, mélico, filósofo e compositor de cançóes. [...] dedicou-se também à lira, sendo posterior a Píndaro e Baquílides mas mais velho do que Melanipes. Estava no máximo da sua fama, por isso, na $78^{\text {a }}$ Olimpíada (= 468-465 a.C.).

(Suda, s.v. Diagoras)

\section{6}

É que também aos antigos, ao que parece, as Musas determinaram que fizessem as suas mais belas e apreciadas composiçóes com o apoio do exílio. "Tucídides o ateniense relatou a guerra entre os Peloponésios e os Atenienses» na Trácia, perto de Escápcia Hile, Xenofonte em Escilunte da Élide, Filisto em Epiro, Timeu de Tauroménion em Atenas, Andrócion, o ateniense, em Mégara, e Baquílides de Iúlis no Peloponeso. Todos estes, e vários outros, foram banidos das 
respetivas pátrias mas não desesperaram nem se entregaram ao pranto, antes deram aso às suas capacidades naturais aceitando o exílio como uma dádiva da sorte, pelo qual seriam lembrados em toda a parte, mesmo depois de mortos. Quanto aos que os baniram e nessa luta contra eles levaram a melhor, nenhum deles prosperou na memória de ninguém. (Plutarco, Acerca do Exílio 14, 605C)

\section{7 \\ É que também eu, que habito um penhasco, sou conhecido pelas glórias dos concursos entre os Helenos, como sou conhecido por às Musas oferecer arte em abundância.}

(Píndaro, Peanes 4.21-24)

\section{$8 \mathbf{a}$}

«Sábio é o homem que conhece muitas coisas por natureza; mas os que aprenderam, com a sua charlatanice, como corvos rudes, que chiem inutilmente em face da ave de Zeus]. 154c: refere-se a Baquílides; foi com efeito seu rival e competiu com ele no mesmo terreno. 157a: como os corvos respondem aos berros à águia, o mesmo fazem quantos aprenderam daquele que é sábio por natureza. Alude a Baquílides e Simónides, considerando-se a si mesmo a águia e os corvos os seus rivais. 158d: Se de algum modo alude a Baquílides e Simónides, isso fica bem claro no dual «que chiem».

(Escólio a Píndaro, Olímpicas 2.154 sqq.)

\section{8b}

«É necessário que eu escape à violenta mordedura da maledicência»] 97: alude a Baquílides; é que ele, com efeito, a toda a hora o caluniava perante Hierão.

«Belo, fica a saber, é o macaco para as crianças, 
sempre belo»] ibid. 131a: dizem alguns que com isto alude a Baquílides; é que este gozava de boa reputação junto de Hierão. 132c: ou assim: como o macaco é um entertenimento para as crianças, ainda que valendo pouco, do mesmo modo Baquílides há de ser estimado entre crianças insensatas, mas junto de ti [Hierão], que és sábio, há de ser apenas um macaco. 132d: alude a Baquílides: do mesmo modo entre as crianças o macaco parece ser belo, mas não é assim entre os homens; é que conhecem perfeitamente o animal. 132e: como entre crianças parece ser belo e gracioso, o mesmo quanto a Baquílides. 132f: pode também ser interpretado assim: Baquílides, entre as crianças, parece ser sábio, mas não entre os adultos.

«Necessário é não se bater com o deus, que ora sustém as coisas de uns, ora a outros concede uma glória imensa.»] 163b: também eu, enfim, cederei a Baquílides, que agora recebe o favor dos deuses, e não me oporei enredado à sua resolução.

«E tirando para si de determinada norma excessiva, cravam uma dolorosa ferida em seu coração.»] 166d: uma referência de novo a Baquílides. $O$ pensamento entendese na medida em que os poemas de Baquílides eram os preferidos de Hierão, e diz que é preciso evidenciar as dádivas da fortuna. (cf. 171c, 171d)

(Escólio a Píndaro, Píticas 2.97)

\section{$8 c$}

«Enquanto os grasnadores corvos por baixo se movimentam»] Parece que estas palavras aludem a Baquílides; havia, com efeito, uma desconfiança mútua entre eles. E compara-se a si próprio com uma águia, ao passo que a Baquílides com um corvo. 
(Escólio a Píndaro, Nemeias 3.143 BDP)

\section{9a}

E depois? Entre os mélicos preferirias ser Baquílides mais do que Píndaro, e na tragédia Íon de Quios, por Zeus, mais do que Sófocles? É que os primeiros são infalíveis e no seu cinzelar tudo está escrito com um estilo sublime, ao passo que Píndaro e Sófocles, por vezes, abrasam com o seu ímpeto, mas apagam-se incompreensivelmente e caem nas maiores desgraças. Ainda assim, alguém em seu perfeito juízo trocaria uma só tragédia de Édipo por toda a obra de Íon?

(Pseudo-Longino, De Sublime 33.5)

\section{9b}

Píndaro, boca sagrada das Musas, e tu, palradora Sirene,

Baquílides, Safo...

(Antologia Grega 9.184.1-2)

9c Baquílides;

e com o encanto da sua boca claramente falou (Antologia Grega 9.571.4)

\section{9d}

Ouvi falar... de um gramático (louco) que julgava ler um livro de Baquílides ou de Safo.

(Galeno, Comm. às Prediçôes de Hipócrates 1.27 pág. $566=1.41 .4$ Diels)

$10=$ fr. 38 


\section{ÍNDICE ONOMÁSTICO}

O elenco apresentado refere-se em exclusivo aos nomes que surgem (ou se depreendem) no texto conservado (epinícios, ditirambos e fragmentos) de Baquílides, incluindo os fragmentos espúrios. De fora deste elenco ficaram os testemunhos reunidos nos Apêndices 1 e 2. Em itálico indicamos os passos cuja ocorrência textual ou não é segura, ou resulta da simples reconstituiçáo pelo sentido do texto. Um asterisco $\left(^{*}\right)$ antecede uma ocorrência dos fragmentos, e um 'E' dos Epigramas.

Abante (mit.): 11.40, 11.69

Acrísio (mit.): 11.66

Admeto: 3.77

Adrasto: 9.19

Afares: 5.128

Afareu: *20A.24

Afrodite: $5.175, \quad 9.72, \quad 17.10$, 17.116, 26.3, *20B.8, *61.2, *64.15

Agatocléades: 14B.2

Agelau: 5.117

Agenor: 19.46

Aglao: 10.9

Ájax: 13.104

Alcmena: $5.71, * 4.42, * 64.6$

Alexandre: *20B.4

Alexidamo: 11.18
Alfeu: 3.6, 5.38, 5.180, 6.3, $8.27,11.26,12.43,13.193$, *20C. 10

Aliates: 3.40

Altaia: $5.120,5.137$

Amazonas: 9.44

Amintas: *20B.17

Amítaon: *4.51

Anceu: 5.117

Anfiarau: 9.16

Anfitrião: 5.85, 5.156, 16.15, 25.25

Anfitrite: 17.110

Antenor: 15.1

Apolo: 1.148, 3.20, 3.29, 3.58, $3.66,3.76,4.2,11.15,13.148$, 16.10, 19.25, 29d.11, *1A.2, $* 4.41, * 4.55, * 20 \mathrm{E} .11$ 
Aqueus: $5.58,11.113,11.126$, Cadmo: 19.48

15.39

Aqueronte: ${ }^{*} 60.18$

Aquiles: 13.101, 13.119, 13.134

Arcádia: 11.94

Arcádios: *8

Ares: 5.34, 5.130, 9.44, 13.146, $18.57,20.11,{ }^{*} 20$ A. $13, * 24.2$

Argeu: 1.142, 2.5

Argivos: 9.11, 15.5

Argo (mit.): 19.19, 19.33

Argos (top.): 10.32, 11.60, 11.81, $19.16, * 4.50$

Aristómenes: 6.12, 7.10

Aristóteles (atleta): 14B.7

Arquémoro: 9.12

Ártemis: 5.99, 5.123, 11.37, $11.98,25.6,28.6$

Asínios: *4.47

Asopo (mit. e top.): 9.39

Atena: 5.92, 13.195, 15.2, 15.3, 17.7

Atenas: 10.17, 18.1, 18.60, 19.10, 23.1

Atenienses: 17.93

Atridas: 11.123

Aurora: 5.40, 13.128, 17.42, *20C. 22

Automedes: 9.25

Bacantes: 19.49

Beócia: 5.191

Baquílides: E1.4

Bóreas: 5.46, 13.125, 17.6, 17.91

Briseida: 13.137
Cálidon: 5.106, *64.7

Calíope: 5.176, 19.13

Casas (top.): 11.119

Castália: 3.20

Ceneu: vd. Zeus

Ceos (top.): 2.2, 3.98, 6.5, 6.16, 8.14, 17.130, 19.11, E1.4

Cércion: 18.26

Ciclopes: 11.77

Cípris: vd. Afrodite

Cirra: 4.15, 11.19, 14B.8, *20C.8

Cleoptólemo (atleta): 14.19

Clímeno: 5.145

Clio: 12.1, 13.9, 13.228

Clítion: 25.29

Cnóssios: 17.39, 26.13

Cnossos (top.): 1.123

Cocito: 5.64

Concórdia (mit.): 15.55

Core: vd. Perséfone

Corinto: 1.13-14, 12.39

Craneus: E1.2

Creso: 3 passim

Creta: 17.4

Cretenses: 1.115

Crémio: 18.24

Creúsa: 18.15

Crónida: vd. Zeus e Poséidon

Cronos: 7.1, 13.79, 17.65

Curetes: 5.126

Daíplo: 5.145

Dámon: 1.138 
Dânao: 11.74

Dânaos: 13.145

Dardânidas: 13.112

Dédalo: 26.7

Deinómenes: 3.7, 4.13, 5.36

Dejanira: $5.173,16.24,{ }^{*} 64.17$

Delfos: 3.21, 3.62, 5.41, 8.17, $12.37,16.1,16.8,16.11$, 29 g. $1, * 4.39$

Delos: 3.58, 11.15, 17.130, 28.9

Deméter: 3.2, 9.97

Destino: *24.5

Dexítea: 1.118

Diónisos: 9.98, 14A.4, 19.50, *20B. 9

Eácidas: 13.166

Éaco: $13.72,13.99,13.182$

Eagro: $29 \mathrm{~d} .8$

Ecália (top.): 16.14

Egina (mit.): 9.55, 13.78

Egina (top.): $10.35,12.5,13.181$

Egípcios: 19.43

Egito: *20B.15

Endeide: 13.96

Eneu: 5.97, 5.119, 5.166

Enidas: 10.18

Enone: ${ }^{*} 20$ D. 3

Épafo: 19.42

Equidina: 5.62

Escamandro: $13.165,27.36$

Esparta: 20.1

Estige: 11.9

Etna: *20C.7
Etólia (top.): 8.30

Etólios: 5.114

Etra: 17.58

Eubeia (top.): 10.34

Eudemo: E2.1

Eunomia (mit.): 13.185

Eupálamo: 26.5

Euribeia: 13.102, 17.14

Europa: 1.124, 17.54

Euxântion: 1.125

Euxanto: 2.8

Eveno: *20A.17

Excelência (mit.): 13.176

Faísco: 11.14

Fama: 2.1, 10.1

Febo: vd. Apolo

Fénice: 17.32

Feres: 3.77

Ferenico: 5.37, 5.182, *20C.9

Fliunte (top.): 9.4

Fortuna (mit.): 14.3

Gigantes: 15.63

Glória (mit.): 3.6, 13.183

Graças: 5.9, 9.1, 10.39, 15.49, 19.6

Gregos: 8.11

Hades: $5.61, * 60.20$

Hálicos: *4.49

Hebro: 16.5

Hécate: * 1 B. 1

Heitor: 13.109, 13.154

Hélade: 3.63

Helenos: 3.12, 5.112, 7.7, 8.22, $9.30,10.20,13.57,13.81$ 
Hélicon: 29a.4

Hélios: 17.50

Hera: 5.89, 9.7, 11.107, 19.22

Héracles: 5 passim, 13.48, 16.15, *4.42, *64.6

Hesíodo: 5.192

Héstia: 14B.1

Hierão: 3.64, 3.92, 4.3, 5.16, $5.49,5.185,5.197,{ }^{*} 20 \mathrm{C} .3$

Hiperbóreos: 3.59

Ida (top.): 5.67, 17.30

Idas (mit.): 20.4, *20A.24

Íficlo: 5.128

Ílion: vd. Tróia

Insolência (mit.): 15.59

Ínico: 19.18

Io: $19.18,19.40$

Íole: 16.27

Iónios: 17.3, 18.2

Istmo (de Corinto): 1.6, 2.7, 8.18, 18.17

Ítaca: $* 29$

Itália: 11.30

Itónia (top.): *15.3

Justiça: 4.12, 15.54, 17.25

Lacedemónios: 20.2

Lácon: 6.1, 7.11

Laertes: 15.6

Lâmpon: 13.68, 13.226

Laomedonte: 13.142

Larissa (top.): 14B.10

Latona: 11.99

Lemnos: $18.56,{ }^{*} 7$
Leto: 3.39, 5.123, 11.16, 28.5, *20D. 5

Leucipo: ${ }^{*} 61$

Lícios: 13.148

Licormas: 16.34

Lídia: $3.24,{ }^{*} 14.1$

Linceu: 11.75

Líparon: 8.9

Liságora: $1.49,1.72$

Lóxias: vd. Apolo

Lusos (top.): 11.96

Macelo: 1.73

Maia (mit.): 19.26

Maldições: *20A.8

Maleia: ${ }^{*} 66.13$

Mantineios: 21.1

Marpessa: 20.6, ${ }^{*} 20$ A. 16, ${ }^{*}$ 20A. 46

Melampo: *4.51

Meleagro: 5 passim

Menandro (treinador): 13.191

Menelau: 15.6, 15.48

Mênfis: *30.1

Metaponto: 11.10, 11.116

Minos: 1.113, 1.124, 17.8, 17.68, 26.12

Mísios: 27.41

Mnemósine: *63.2

Moira, Moiras: 24.8

Morte (mit.): *20E. 8

Musa, Musas: 3.71, 3.92, 5.4, $5.192,9.3,9.87,13.222$, $14 A .5,15.47,19.4,29 \mathrm{~d} .9$, *20B.4, *20C.3, *21.5, *55.2, E1.3 
Nemeia (Leão de): 9.9, 13.47

Nemeia (vale de): 8.18, 9.22, $9.82,10.29,12.8,13.67$

Nereide, Nereides: 13.123, 17.38, 17.102

Nereu: 1.8, 17.103

Nesso: $16.35,{ }^{*} 66.10,{ }^{*} 64.16$

Nilo: 9.41, 19.39, *30.2

Níobe: *20D.4

Noite: $7.2,{ }^{*} 1$ B. 3

Noto: 13.130

Oicles: 9.16

Olímpia: 6.6, 7.3

Olimpo: $11.4,{ }^{*} 20 \mathrm{E} .8,{ }^{*} 63.5$

Orfeu: $29 \mathrm{~d} .8$

Páctolo: 3.45

Palante: E1.1

Palas: vd. Atena

Palene (top.): 10.33

Pandíon: $17.15,18.15$

Pântides: 1.147, 2.14

Páris: *20D. 2

Pasífae: 26.2

Paz (mit.): *4.61, *4C

Peleu: 13.97, 13.110

Pélops: 1.14, 5.181, 8.32, 11.25

Pélops, ilha de: vd. Corinto

Peneu (top.): 14B.5

Periclito: * 16.1

Persas: 3.27

Perséfone (ou Core): 3.2, 5.59

Perseu: 13.48

Piéria (top.): 16.3, 19.4
Piérides: $1.3,19.35,{ }^{*} 63.1$

Pirene (mit.): 9.62

Pírrico: 14.22

Pisa: 5.182

Píteas (atleta): 13.191

Piteu: 17.34

Pítio: vd. Apolo

Pito (top.): vd. Delfos

Plêuron: 5.151, 20.10

Plístenes: 15.48

Polinices: 9.20

Polipémon: 18.28

Portáon: 5.70

Poséidon: 10.19, 14.20, 17.36, 17.59, 17.78, 20.8, 21.2, *20A.23

Preto (mit.): 11.66, 11.84

Príamo: 11.122, 15.38

Procáon: 25.29

Procoptas: 18.28

Querolau: 7.13

Quíron: 27.35

Reputação: 9.1

Sardes: 3.27

Sarpéon: *20E.10

Scíron: 18.25

Sémele: 19.48

Sicília: 3.1

Sícion (top.): 10.32

Simoente: *20E.16

Sínis: 18.19

Siracusa: 4.1, 5.184

Siracusanos: 5.1 
ÍNDICE TEMÁTICO

Sono (mit.): *20E.7

Tálaon: 9.19

Teano: 15.7

Tebe: 9.53

Tebas: 9.20, 10.30, 19.47

Télamon: 13.98

Témis: 15.55

Teócrito: *18.1

Termodonte: 99.43

Terra: $15.63,19.32$

Teseu: 17.1, 17.16, 17.74, 17.99

Tessália: 14B.6, 18.54

Téstio: 5.137

Timóxeno: 9.102

Tirinte (top.): 11.57, 11.71

Trezena: 17.58

Tróia: 8.46, 11.122, 13.116, 15.10, *60.24

Troianos: 13.133, 15.42, 15.50, 27.38

Ulisses: 15.5

Urânia: 4.8, 5.13, 6.10, 16.3

Urano: 11.3

Verdade (mit.): *57.1

Vitória: 3.5, 5.33, 6.11, 10.6, 10.15, $11.1,12.5,13.59, \mathrm{E} 1.1$

Zéfiro: 5.29, E2.2

Zeus: 1.1, 1.116, 1.155, 3.11, 3.55, $3.70,5.20,5.58,5.79,5.178$, 5.200, 6.1, 7.4, 8.26, 9.5, 9.56, $9.100, \quad 10.30, \quad 11.5, \quad 11.52$, $11.73,12.40,13.58,13.79$, $15.51,16.17,16.28,17.20$, $17.30,17.52,17.68,17.75$, $17.86,18.21,19.17,19.30$,
19.41, 25.19, 29a.2, 29b.7, *57.1, *20C. $14,{ }^{*} 20$ D. 8 


\section{Textos Gregos Publicados}

1. Delfim F. Leão e Maria do Céu Fialho: Plutarco. Vidas Paralelas - Teseu e Rómulo. Tradução do grego, introdução e notas (Coimbra, CECH, 2008).

2. Delfim F. Leão: Plutarco. Obras Morais - O banquete dos Sete Sábios. Tradução do grego, introdução e notas (Coimbra, CECH, 2008).

3. Ana Elias Pinheiro: Xenofonte. Banquete, Apologia de Sócrates. Tradução do grego, introdução e notas (Coimbra, CECH, 2008).

4. Carlos de Jesus, José Luís Brandão, Martinho Soares, Rodolfo Lopes: Plutarco. Obras Morais - No Banquete $I$ - Livros I-IV. Tradução do grego, introdução e notas. Coordenação de José Ribeiro Ferreira (Coimbra, CECH, 2008).

5. Ália Rodrigues, Ana Elias Pinheiro, Ândrea Seiça, Carlos de Jesus, José Ribeiro Ferreira: Plutarco. Obras Morais - No Banquete II - Livros V-IX. Tradução do grego, introdução e notas. Coordenação de José Ribeiro Ferreira (Coimbra, CECH, 2008).

6. Joaquim Pinheiro: Plutarco. Obras Morais - Da Educação das Crianças. Tradução do grego, introdução e notas (Coimbra, CECH, 2008).

7. Ana Elias Pinheiro: Xenofonte. Memoráveis. Tradução do grego, introdução e notas (Coimbra, CECH, 2009). 
8. Carlos de Jesus: Plutarco. Obras Morais - Diálogo sobre o Amor, Relatos de Amor. Tradução do grego, introdução e notas (Coimbra, CECH, 2009).

9. Ana Maria Guedes Ferreira e Ália Rosa Conceição Rodrigues: Plutarco. Vidas Paralelas - Péricles e Fábio Máximo. Tradução do grego, introdução e notas (Coimbra, CECH, 2010).

10. Paula Barata Dias: Plutarco. Obras Morais - Como Distinguir um Adulador de um Amigo, Como Retirar Benefício dos Inimigos, Acerca do Número Excessivo de Amigos. Tradução do grego, introdução e notas (Coimbra, CECH, 2010).

11. Bernardo Mota: Plutarco. Obras Morais - Sobre a Face Visivel no Orbe da Lua. Tradução do grego, introdução e notas (Coimbra, CECH, 2010).

12. J. A. Segurado e Campos: Licurgo. Oração Contra Leócrates. Tradução do grego, introdução e notas (Coimbra, CECH /CEC, 2010).

13. Carmen Soares e Roosevelt Rocha: Plutarco. Obras Morais - Sobre o Afecto aos Filhos, Sobre a Música. Tradução do grego, introdução e notas (Coimbra, $\mathrm{CECH}, 2010)$.

14. José Luís Lopes Brandão: Plutarco. Vidas de Galba e Otão. Tradução do grego, introdução e notas (Coimbra, CECH, 2010). 
15. Marta Várzeas: Plutarco. Vidas de Demóstenes e Cícero. Tradução do grego, introdução e notas (Coimbra, $\mathrm{CECH}, 2010)$.

16. Maria do Céu Fialho e Nuno Simóes Rodrigues: Plutarco. Vidas de Alcibiades e Coriolano. Traduçáo do grego, introdução e notas (Coimbra, CECH, 2010).

17. Glória Onelley e Ana Lúcia Curado: Apolodoro. Contra Neera. [Demóstenes] 59. Tradução do grego, introdução e notas (Coimbra, CECH, 2011).

18. Rodolfo Lopes: Platão. Timeu-Critías. Tradução do grego, introduçáo e notas (Coimbra, CECH, 2011).

19. Pedro Ribeiro Martins: Pseudo-Xenofonte. A Constituição dos Atenienses. Tradução do grego, introdução, notas e índices (Coimbra, CECH, 2011).

20. Delfim F. Leão e José Luís L. Brandão: Plutarco.Vidas de Sólon e Publicola. Tradução do grego, introdução, notas e índices (Coimbra, CECH, 2012).

21. Custódio Magueijo: Luciano de Samósata I. Tradução do grego, introdução e notas (Coimbra, CECH/IUC, 2012).

22. Custódio Magueijo: Luciano de Samósata II. Tradução do grego, introdução e notas (Coimbra, CECH/IUC, 2012).

23. Custódio Magueijo: Luciano de Samósata III. Tradução do grego, introdução e notas (Coimbra, CECH/IUC, 2012). 
24. Custódio Magueijo: Luciano de Samósata IV. Tradução do grego, introdução e notas (Coimbra, CECH/IUC, 2013).

25. Custódio Magueijo: Luciano de Samósata $V$. Tradução do grego, introdução e notas (Coimbra, CECH/IUC, 2013).

26. Custódio Magueijo: Luciano de Samósata VI. Tradução do grego, introdução e notas (Coimbra, CECH/IUC, 2013).

27. Custódio Magueijo: Luciano de Samósata VII. Tradução do grego, introdução e notas (Coimbra, CECH/IUC, 2013).

28. Custódio Magueijo: Luciano de Samósata VIII. Tradução do grego, introdução e notas (Coimbra, CECH/IUC, 2013).

29. Custódio Magueijo: Luciano de Samósata IX. Tradução do grego, introdução e notas (Coimbra, CECH/IUC, 2013).

30. Reina Marisol Troca Pereira: Hiérocles e Filágrio. Philogelos (O Gracejador). Tradução do grego, introdução e notas (Coimbra, CECH/IUC, 2013).

31. J. A. Segurado e Campos: Iseu. Discursos. VI. A herança de Filoctémon. Tradução do grego, introdução e notas (Coimbra, CECH/IUC, 2013).

32. Nelson Henrique da Silva Ferreira: Aesopica: a fábula esópica e a tradição fabular grega. Estudo, tradução do grego e notas. (Coimbra, CECH/IUC, 2013). 
33. Carlos A. Martins de Jesus: Baquílides. Odes e Fragmentos Tradução do grego, introdução e notas (Coimbra, CECH/IUC, 2014). 
IMPRESSÃO:

Artipol - Artes tipográficas, Lda.

Zona industrial de Mourisca do Vouga, Apartado 3051 3754-901 ÁguedA 
Até ao final do século XIX era ínfima a quantidade de texto que se conhecia de Baquílides, ele que, por essa altura, foi o protagonista de uma das mais importantes descobertas papirológicas no que à literatura grega diz respeito. Estávamos em 1896 quando, num túmulo da aldeia de Meir, perto de Al-Kussîyah, no Egito, um grupo de nativos descobriu o rolo de papiro que continha grande parte de uma ediçáo de Baquílides datada do século I a.C. O imenso trabalho de organização, leitura e fixação textual de F. G. Kenyon (1897) simplesmente presenteou o mundo com mais um poeta grego. Um poeta que, sabemos e aceitamos hoje sem pudor, trabalhou para os mesmos patronos, elogiou alguns dos mesmos vencedores e compôs para as mesmas cidades que o grande Píndaro, com ele e com outros (dos quais pouco ou nada sabemos) partilhando o mesmo contexto de patronato e mobilidade artística de finais da época arcaica. 


\section{OBRA PUBLICADA \\ COM A COORDENAÇÁO \\ CIENTÍFICA}

0
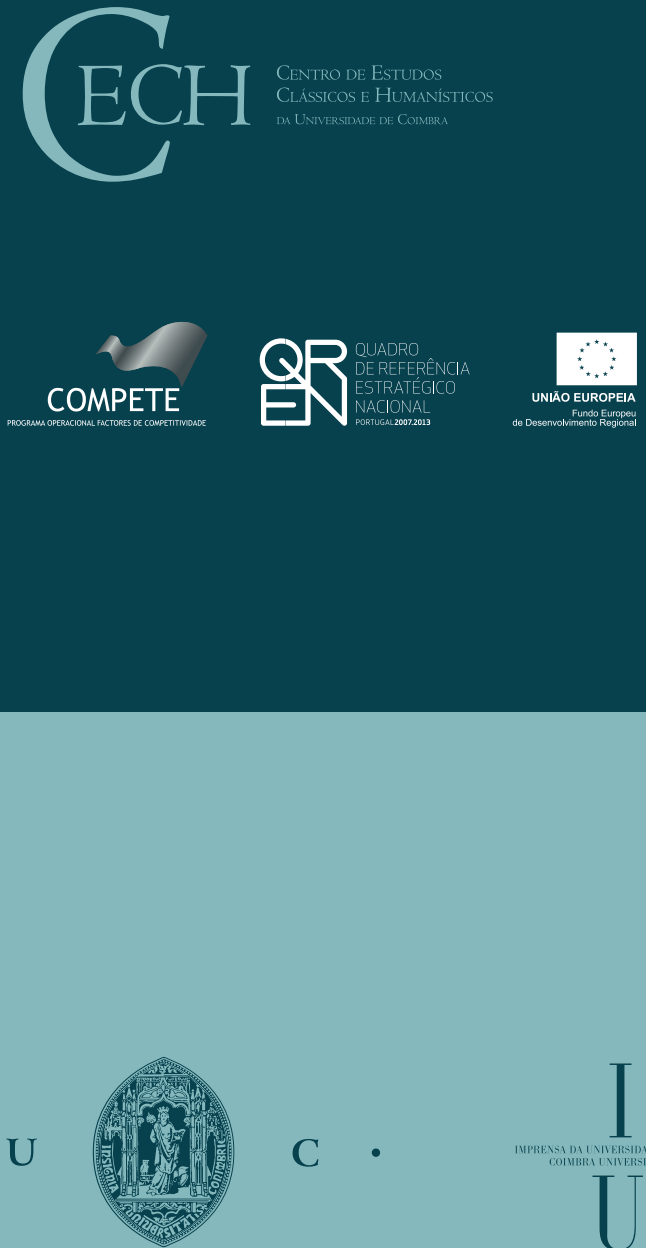

C •

MPRENSA DA IVIIERSIDADE DE COIVBPA 